\title{
Republic of Latvia: First Review and Financing Assurances Review Under the Stand-By Arrangement, Requests for Waivers of Nonobservance of Performance Criteria, and Rephasing of Purchases Under the Arrangement
}

The following documents have been released and are included in this package:

- $\quad$ The staff report, prepared by a staff team of the IMF, following discussions that ended on July 27, 2009, with the officials of the Republic of Latvia on economic developments and policies. Based on information available at the time of these discussions, the staff report was completed on August 7, 2009. The views expressed in the staff report are those of the staff team and do not necessarily reflect the views of the Executive Board of the IMF.

- $\quad$ A statement by the IMF staff representative.

- $\quad$ A Press Release summarizing the views of the Executive Board as expressed during its August 27, 2009 discussion of the staff report that completed the review.

- $\quad$ A statement by the Executive Director for the Republic of Latvia

The document(s) listed below were separately released.

Letter of Intent sent to the IMF by the authorities of the Republic of Latvia*

Technical Memorandum of Understanding*

Informational Annex

*Also included in Staff Report

The policy of publication of staff reports and other documents allows for the deletion of market-sensitive information.

Copies of this report are available to the public from

International Monetary Fund $\bullet$ Publication Services

$70019^{\text {th }}$ Street, N.W. $\bullet$ Washington, D.C. 20431

Telephone: (202) 623-7430 • Telefax: (202) 623-7201

E-mail: publications@imf.org Internet: http://www.imf.org

\section{International Monetary Fund Washington, D.C.}


INTERNATIONAL MONETARY FUND

\title{
REPUBLIC OF LATVIA
}

\section{First Review and Financing Assurances Review Under the Stand-By Arrangement, Requests for Waivers of Nonobservance of Performance Criteria, and Rephasing of Purchases Under the Arrangement}

\author{
Prepared by the European Department \\ (In Consultation with Other Departments)
}

Approved by Marek Belka and Reza Moghadam

August 7, 2009

Stand-By Arrangement: A 27-month SDR 1.52 billion SBA involving exceptional access (1,200 percent of quota) was approved by the Executive Board on December 23, 2008 (Country Report No. 09/3). A first purchase of SDR 535 million was made following the Board meeting. A Staff Report for the Interim Review under the Emergency Financing Mechanism (Country Report No. 09/125) was issued on February 23, 2009. A purchase of SDR 178 million becomes available on completion of this First Review.

Program status: The downturn has been far steeper than envisaged when the program was launched, causing a collapse in tax revenues. In addition, not all of the budget measures agreed last December were implemented. This has caused the fiscal deficit to widen well above program targets. Corrective measures were delayed by the change in government, with the supplementary budget only passed in mid-June. However, the current account has moved into surplus, and endMarch 2009 performance criteria for net international reserves and net domestic assets were met. Steps have been taken to reduce instability in the financial sector, though it remains fragile.

Discussions were held in Riga during February 17-27, May 27-June 19 and July 12-27, 2009. The mission met with President Zatlers; Prime Ministers Dombrovskis and Godmanis; Finance Ministers Repše and Slakteris, government ministers, and coalition leaders; Bank of Latvia Governor Rimšēvičs; Head of the Financial and Capital Market Commission Krūmane; senior officials in these institutions; social partners, and representatives of financial institutions.

Staff. The staff team comprised Anne-Marie Gulde-Wolf (head, July mission), Mark Griffiths (head, June mission), Christoph Rosenberg (head, February mission); Lone Christiansen, Gavin Gray, David Moore (all EUR), Francois Michel (FAD), Yan Liu (LEG), Michaela Erbenova (MCM), Chris Marsh and Guillermo Tolosa (SPR). Alvar Kangur, Jay Surti (EUR), and David Parker (MCM) joined the February mission. Sijmen de Ranitz (Legal expert) joined the first two missions. The team worked closely with staff of the European Commission, ECB, World Bank, and the Swedish authorities. Jens Henriksson and Martins Bitans (OED) attended some meetings.

Publication: The Latvian authorities authorize publication of the staff report, the Letter of Intent, and its attachments. 
I. Introduction and Summary

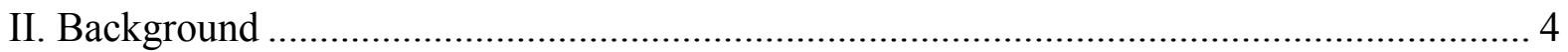

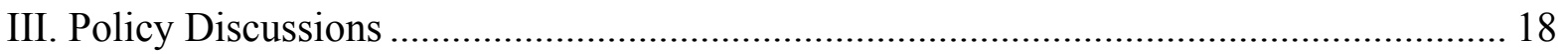

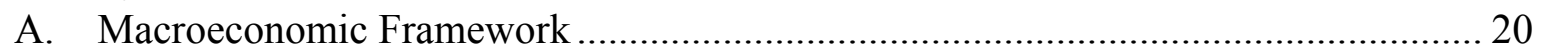

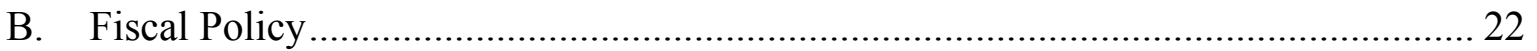

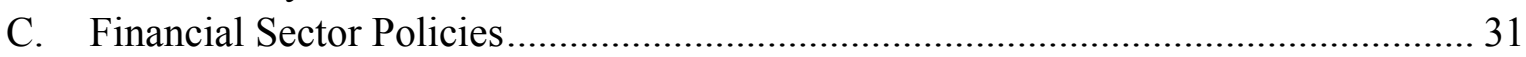

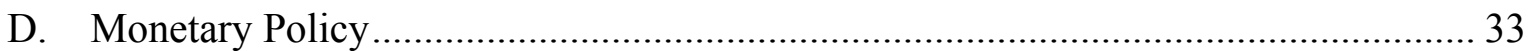

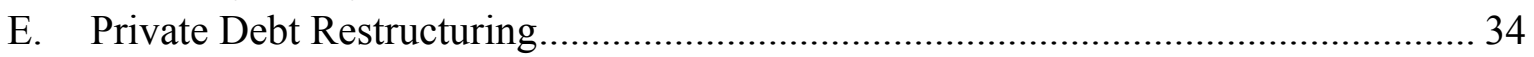

IV. Program Modalities and Safeguards Assessment ........................................................... 34

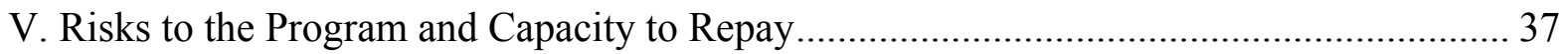

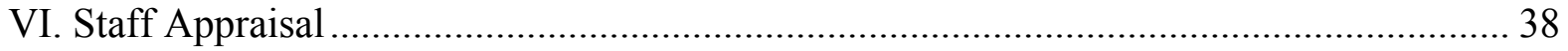

Boxes

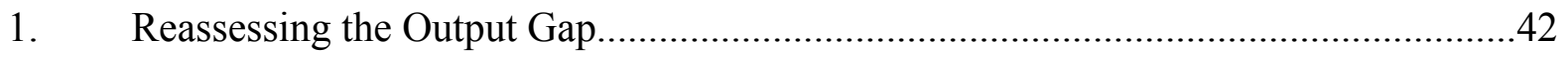

2. Currency Board Adjustment: The Experience of Hong Kong SAR ………….............44

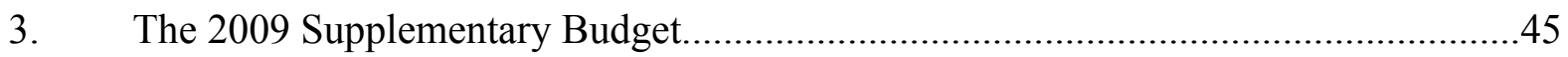

4. Specific Issues Raised by Staff Regarding the Supplementary Budget........................46

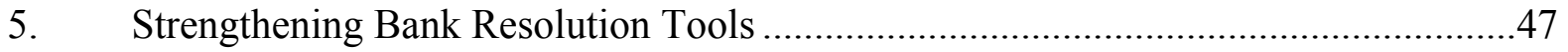

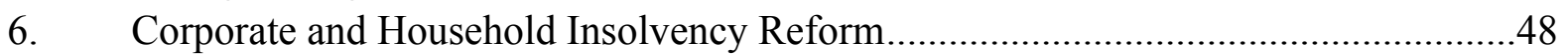

7. Proposed Structural Conditionality Under the Stand-By Arrangement........................49

Figures

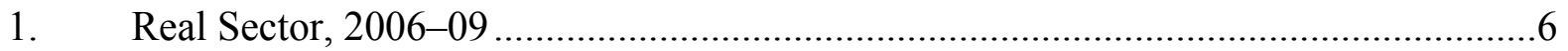

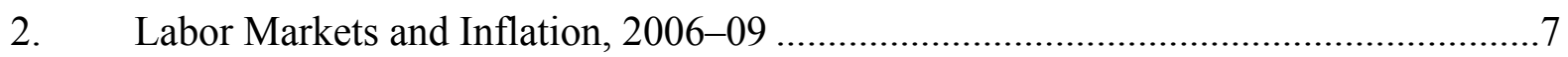

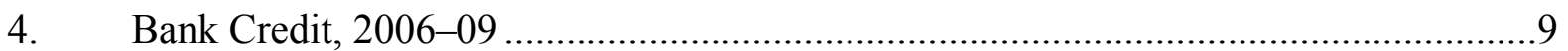

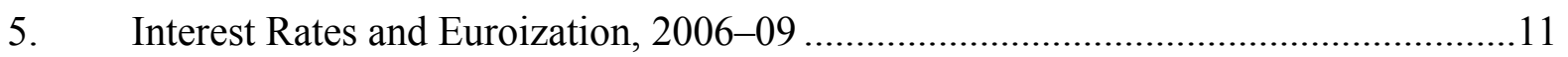

6. Base Money and BoL's Net Domestic Assets, 2008-09 …….................................12

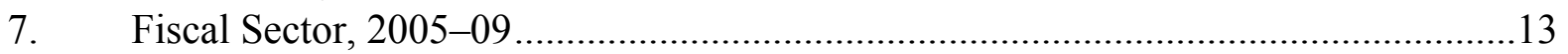

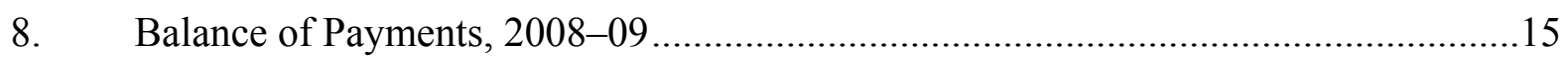

9. Net International Reserves and FX Market Developments ........................................17

10. Banking Sector Profitability and Solvency, 2006-09.................................................

12. Public Debt Sustainability, Bound Tests (Program Scenario) …….............................28

13. Program and Rapid Adjustment Scenarios, July 2009 ..............................................29

14. External Debt Sustainability, Bound Tests ................................................................ 
Tables

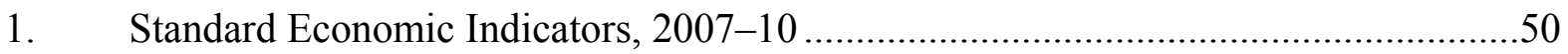

2. Bank of Latvia Balance Sheet, 2005-10 ..................................................................51

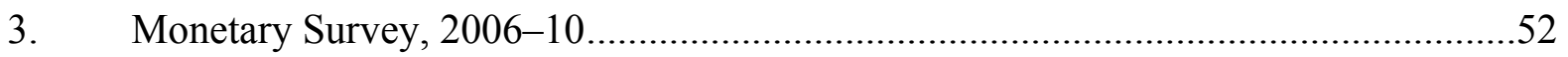

4. Financial Soundness Indicators, 2007-09.............................................................53

5. Macroeconomic Framework, 2007-10 …...............................................................544

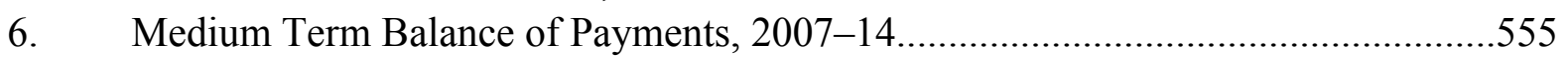

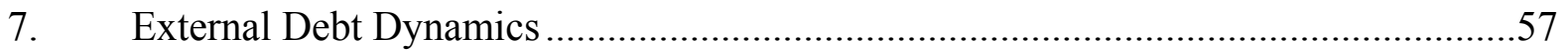

8. External Debt Sustainability Framework, 2004-14 …..............................................58

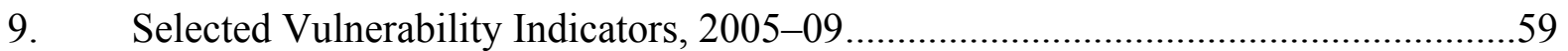

10. General Government Operations: Baseline Before the Supplementary

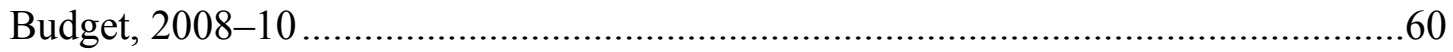

11. Impact of the Supplementary Budget and Additional Amendments on the General Government's Basic: Fiscal Balance, 2009-10.......................................62

12. General Government Operations: Rapid Adjustment Scenario, 2008-14 ................63

13. Public Sector Debt Sustainability Framework, Rapid Adjustment

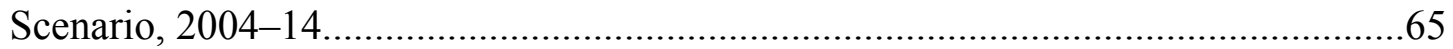

14. General Government Operations: Program Scenario, 2008-14 ..............................66

15. Public Sector Debt Sustainability Framework, Program Scenario, 2004-14 .............68

16. Schedule of Reviews and Purchases .....................................................................69

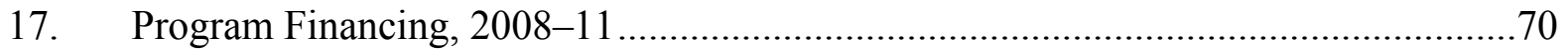

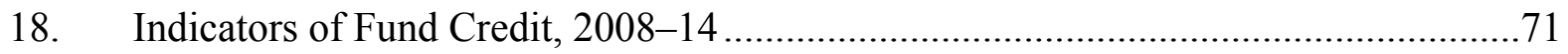

\section{Annexes}

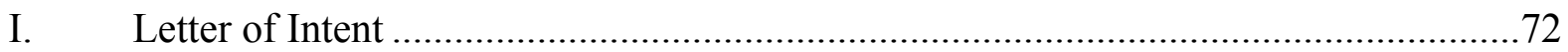

II. Technical Memorandum of Understanding (TMU) ..........................................90 


\section{INTRODUCTION AND SUMMARY}

1. The economic situation has deteriorated markedly since the launch of the program reflecting the collapse of domestic demand, the unwinding of the credit and real estate bubble, and the much worse than expected international environment. These developments have led to a rapid correction in the current account. They have also eroded government revenues, opening a large fiscal gap, and have increased losses in the financial sector. As a result, Latvia's exchange rate peg has faced waves of heavy pressure.

2. The political and economic outlook remains extremely difficult:

- $\quad$ Staff and the authorities project that GDP will fall 18 percent this year, with a slow recovery to take hold only in the second half of next year. Much of this output loss will be permanent, though the still-large negative output gap implies significant deflationary pressures for the next year or two.

- Public discontent is a concern. The coalition parties did poorly at the municipal and European elections on June 6, and lost control of Riga city council. The coalition also faces deep internal divisions. All coalition parties signed the Letter of Intent, notwithstanding earlier questions by some of them on the need for a Fund arrangement. Opposition to spending cuts has been subdued since January's demonstrations, but could pick up during the winter when unemployment benefits run out for many, and the heating season begins.

3. Against this backdrop, substantial progress has been achieved in stabilizing the financial sector. Since the financial and balance of payments crisis last year when the program was launched, the authorities have strengthened their intervention capacity, financial supervision and monitoring framework, and have taken steps to contain risks in Parex bank.

4. However, the collapse in output has revealed significant underlying fiscal weaknesses that risk leading to unsustainable deficits in the absence of strong corrective measures. Discussions therefore centered on defining a sustainable and structurally sound strategy for fiscal reform, consistent with the Latvian authorities' strategy to maintain the pegged exchange rate, while minimizing further pressure on economic activity and protecting the most vulnerable at a time of painful dislocation.

\section{BACKGROUND}

5. The downturn has proven much deeper than anticipated at the launch of the program (Figures 1-2, Table 1). Real GDP fell by 18 percent year-on-year in the first quarter of 2009 (131/2 percent quarter-on-quarter, seasonally adjusted), compared with the program projection of a 5 percent decline for 2009 as whole. The main causes are the bursting of the credit and real estate bubble, and a collapse in domestic demand: 
- $\quad$ Retail sales fell 25 percent year-on-year in the first quarter of 2009, reflecting declines in household incomes and consumer confidence. Construction and consumer durables spending have fallen even faster (car sales down 80 percent in the first quarter), in part reflecting the credit crunch. Although the level of retail sales seems to have stabilized in the second quarter, year-on-year declines remain substantial.

- $\quad$ Registered unemployment increased to 11/2 percent by end-June, up from 7 percent at the end of last year. Labor force survey estimates put unemployment at 14 percent in the first quarter, above the peak projected for the program period.

6. The deeper downturn is also in part explained by the much worse than projected international environment (Figure 3). Instead of increasing by $1 \frac{1}{2} 2$ percent (the October 2008 WEO projection), output in Latvia's main trading partners is now projected to decline by 5 percent. Partner country currencies have also depreciated sharply, so thatdespite rapidly falling domestic inflation-Latvia's real effective exchange rate has appreciated by 3 percent since the start of the program. This has complicated the original program strategy of internal devaluation through wage and price declines, driven by the authorities' determination to keep the fixed exchange rate. ${ }^{1}$

7. Prices and wages have started to fall. Excluding increases in VAT and excises, since December monthly inflation has been close to zero or slightly negative. Headline inflation has fallen from a peak of 18 percent year on year in mid-2008 to around 3 percent in June. Official data show wages fell 2 percent (quarter on quarter) in the first three months of this year. But the true decline is likely much deeper, since private employers are sharply reducing undeclared cash bonuses. A tripartite committee to promote wage restraint was established in January (structural benchmark), but its effectiveness is uncertain.

\section{Credit contraction has exacerbated the downturn, while the demand for lats has fallen (Figure 4):}

- After funding a credit boom from 2004 to 2007, some foreign-owned banks are scaling back. An increase in their exposure in late 2008 was reversed in the first quarter, when they repaid $€ 0.8$ billion, or just under 10 percent, of their liabilities to their parent institutions. This included a $€ 0.4$ billion reversal of extraordinary shortterm credit extended in late 2008. Lending standards and margins have tightened, so that overall credit has fallen 3 percent since December.

\footnotetext{
${ }^{1}$ The pros and cons of this strategy are described in detail in paragraphs 19-20 and Box 1 of the original program document (Country Report No. 09/3).
} 
Figure 1. Latvia: Real Sector, 2006-09
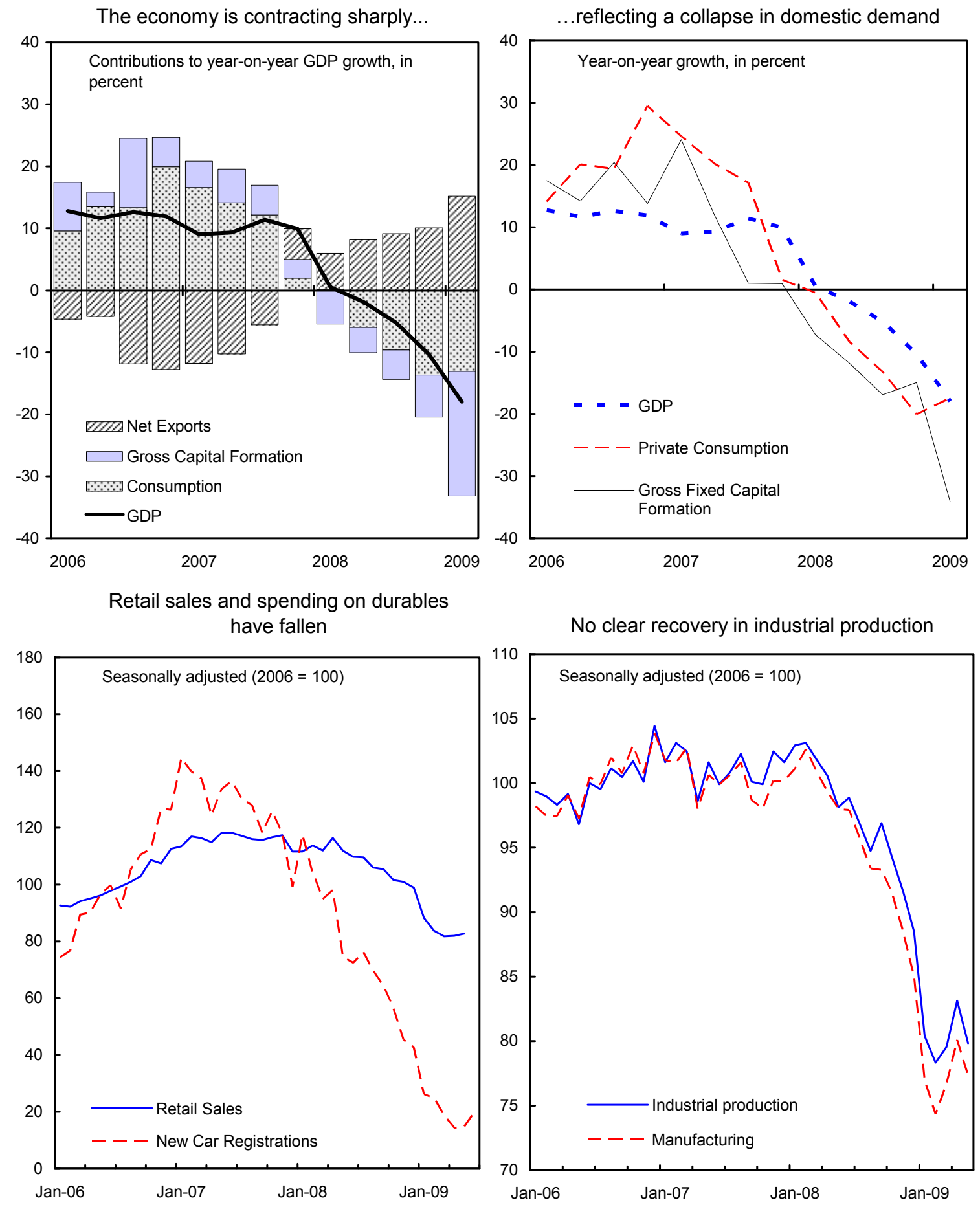

Sources: Latvian Central Statistical Bureau, Haver, Fund Staff Calculations 
Figure 2. Latvia: Labor Markets and Inflation, 2006-09
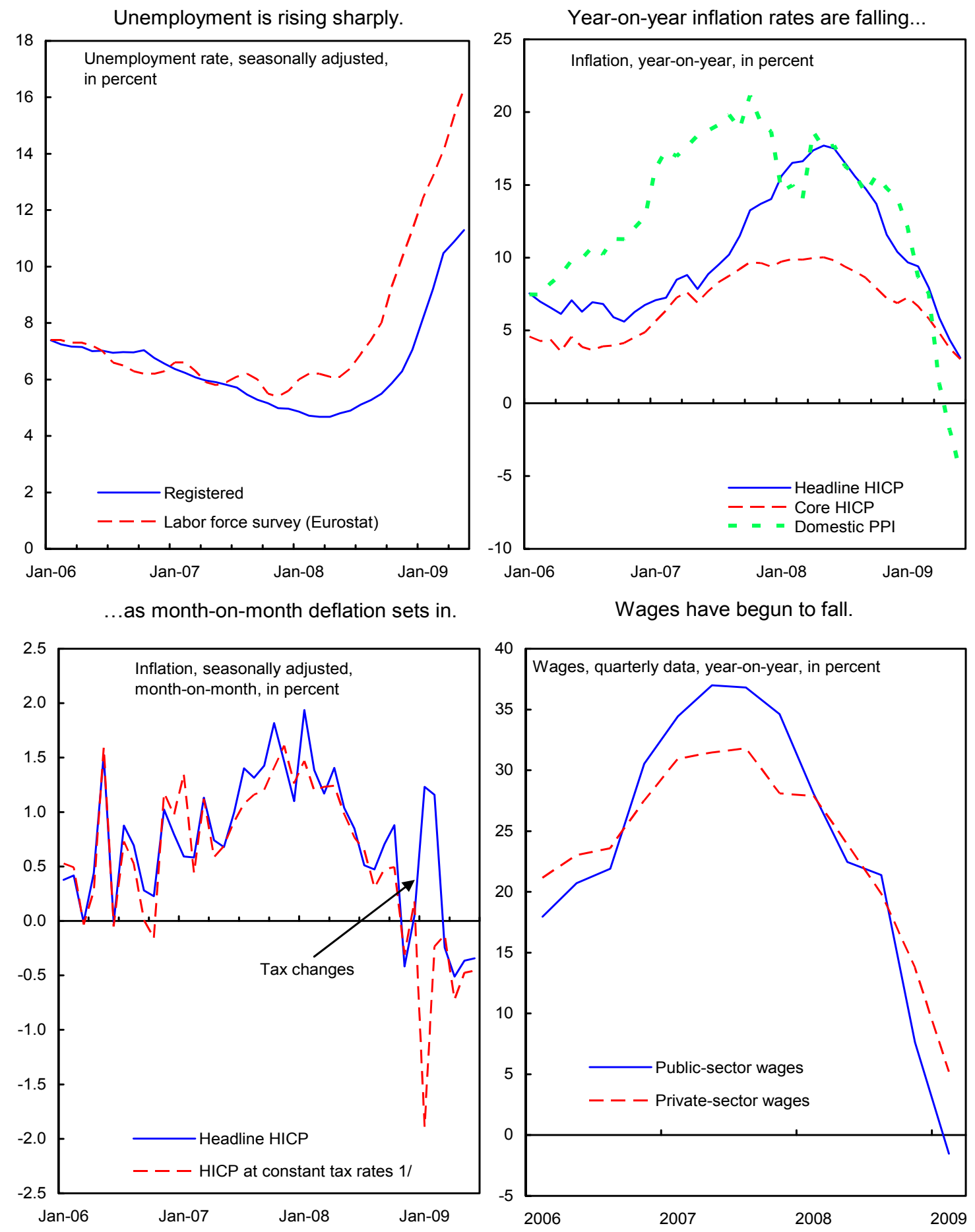

Sources: Eurostat, Haver, Latvian Central Statistical Bureau, Fund Staff Calculations.

1/ HICP at constant tax rates is estimated as HICP, excluding the influence of indirect taxes (excise, VAT and car registration) on consumer prices. It assumes immediate and complete pass-through, and so likely overestimates the effect of taxes on HICP. 
Figure 3. Latvia: Competitiveness and the Global Outlook, 2004-09

The outlook in trading partners has

repeatedly been revised downwards...

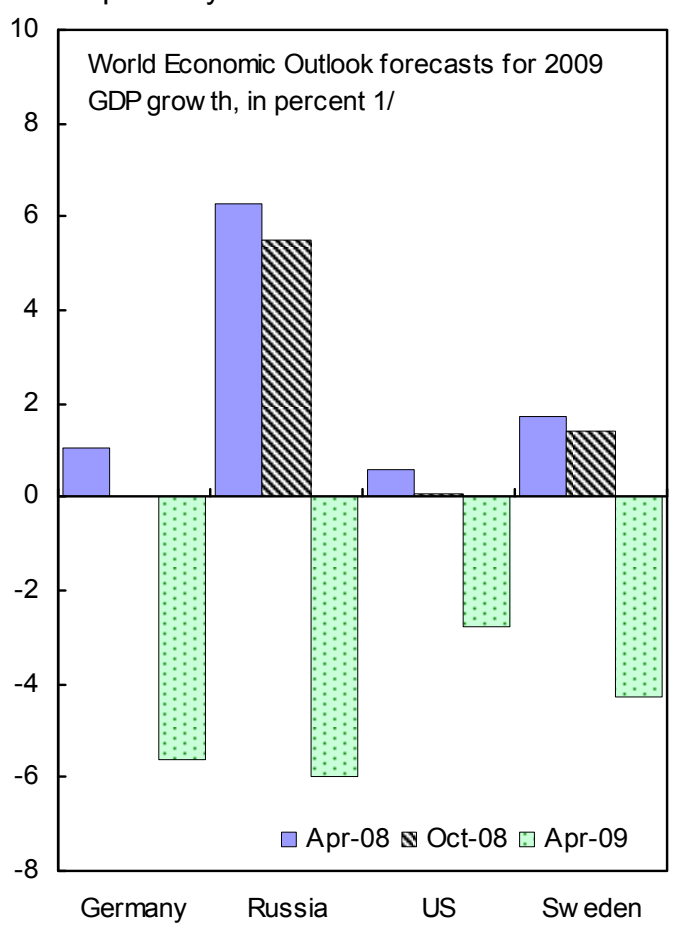

...and activity is now projected to fall sharply.

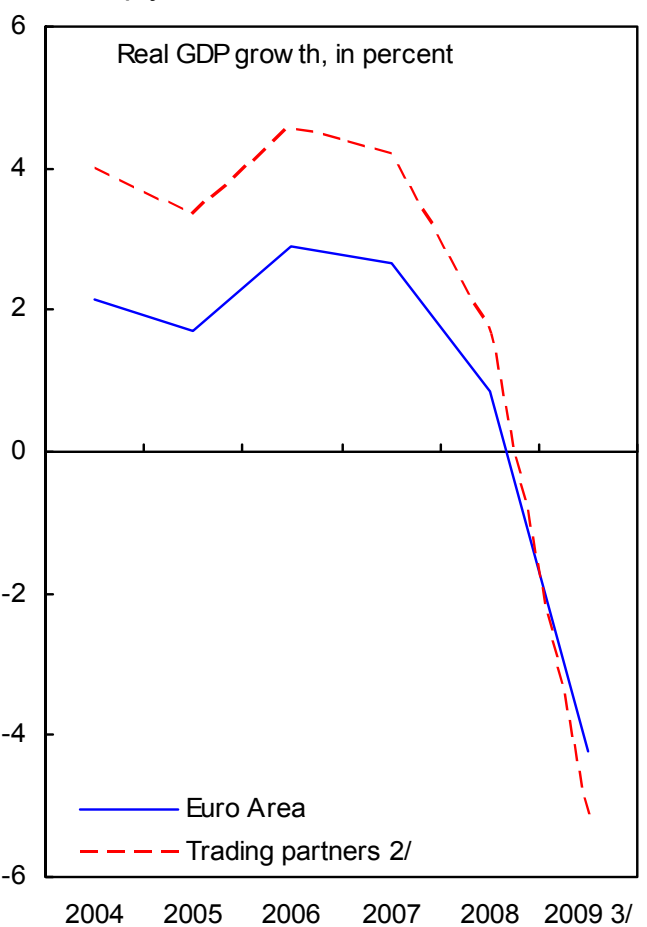

The real exchange rate appreciated steadily, but is starting to correct

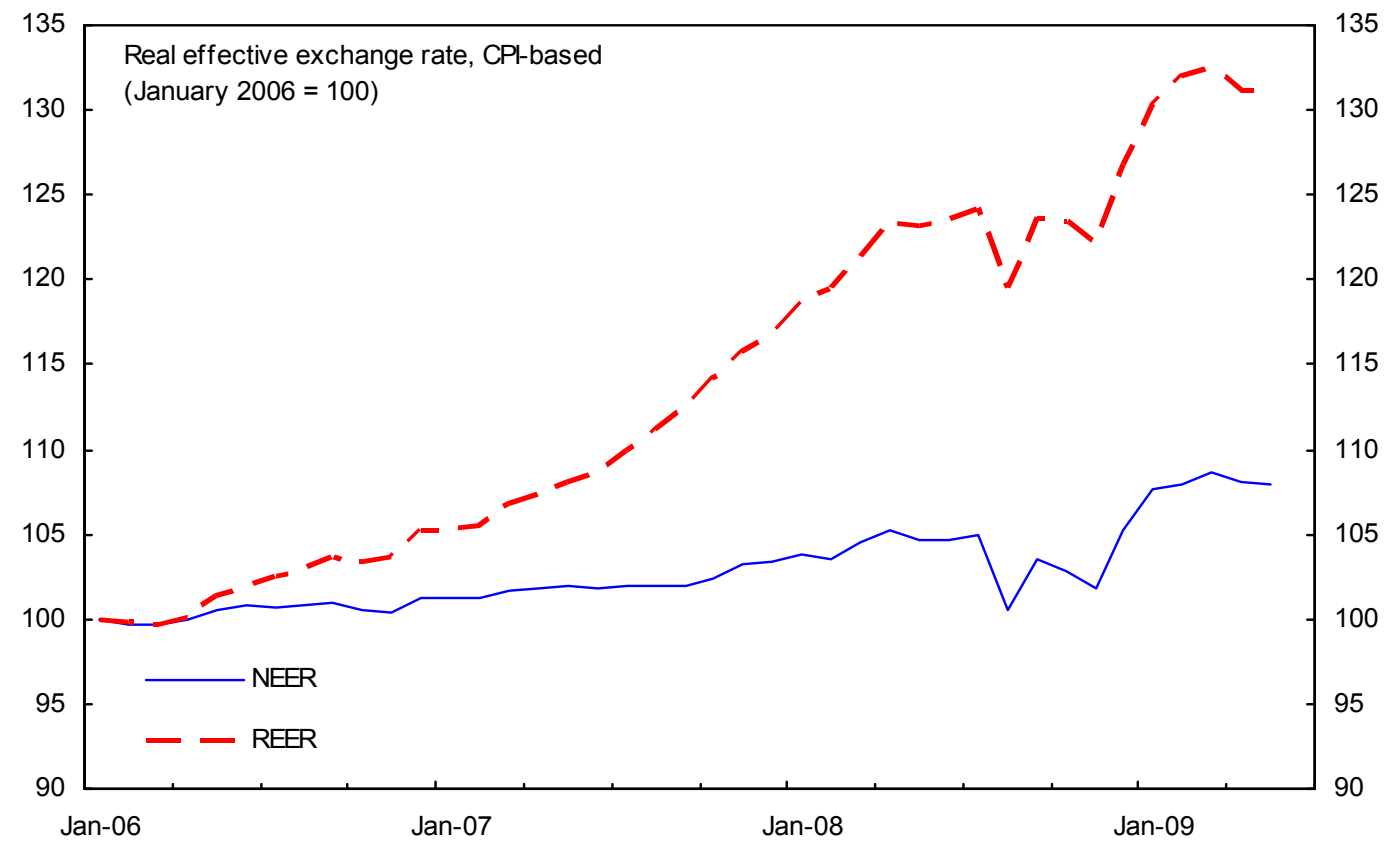

Sources: INS, World Economic Outlook, IMF Staff Calculations.

$1 /$ Dates denote different vintages.

2/ Calculated as average of trading partner growth rates, using INS trade weights.

3/ Projected. 
Figure 4. Latvia: Bank Credit , 2006-09

Banks are repaying liabilities to foreign lenders...

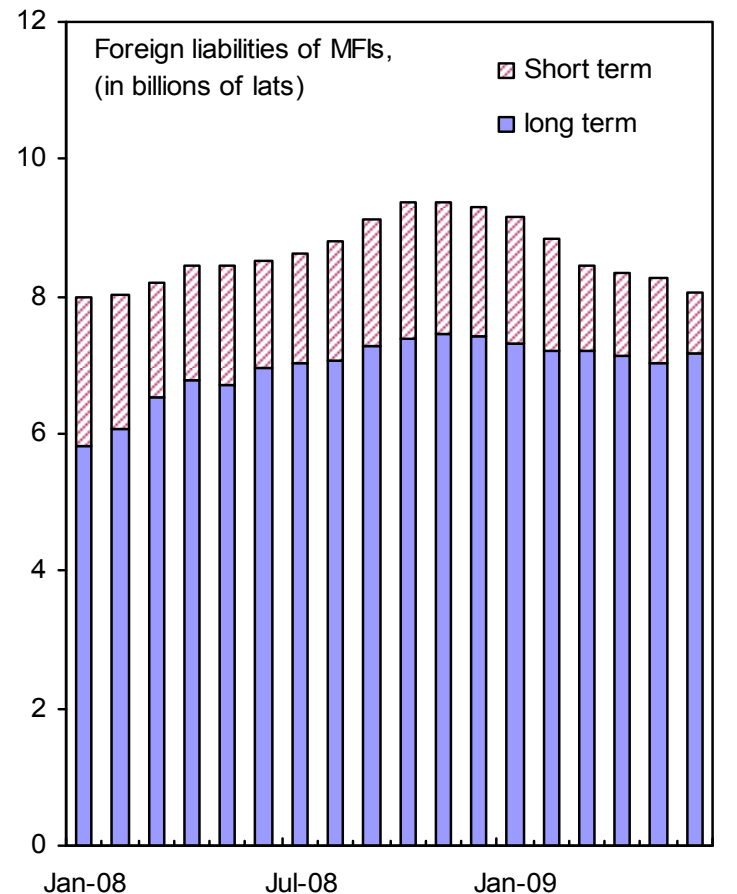

Foreign banks caused the credit boom as well as the recent contraction in credit

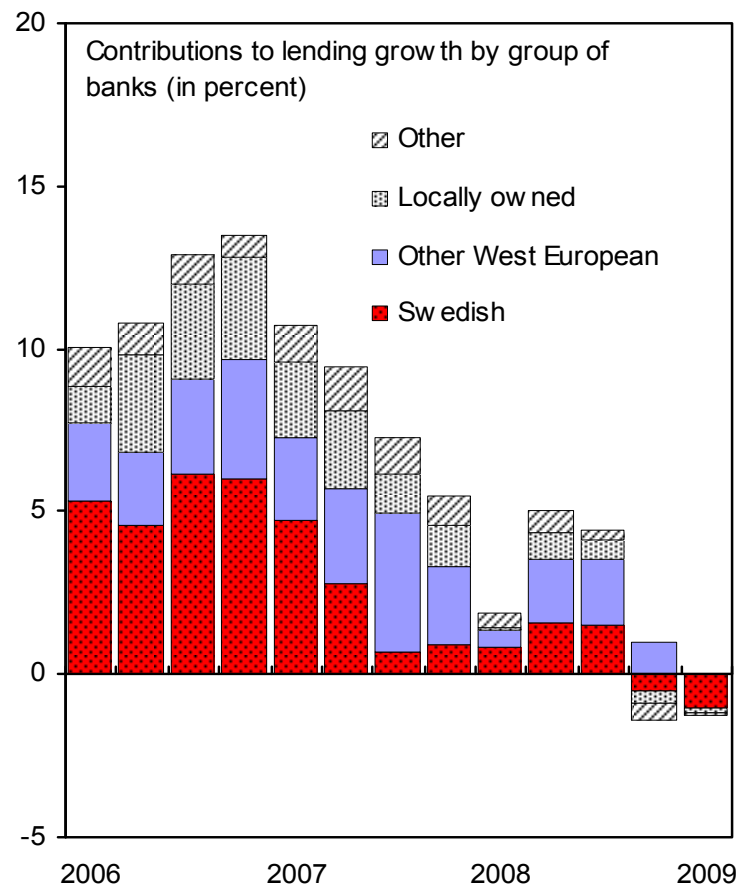

...which has led to a credit crunch

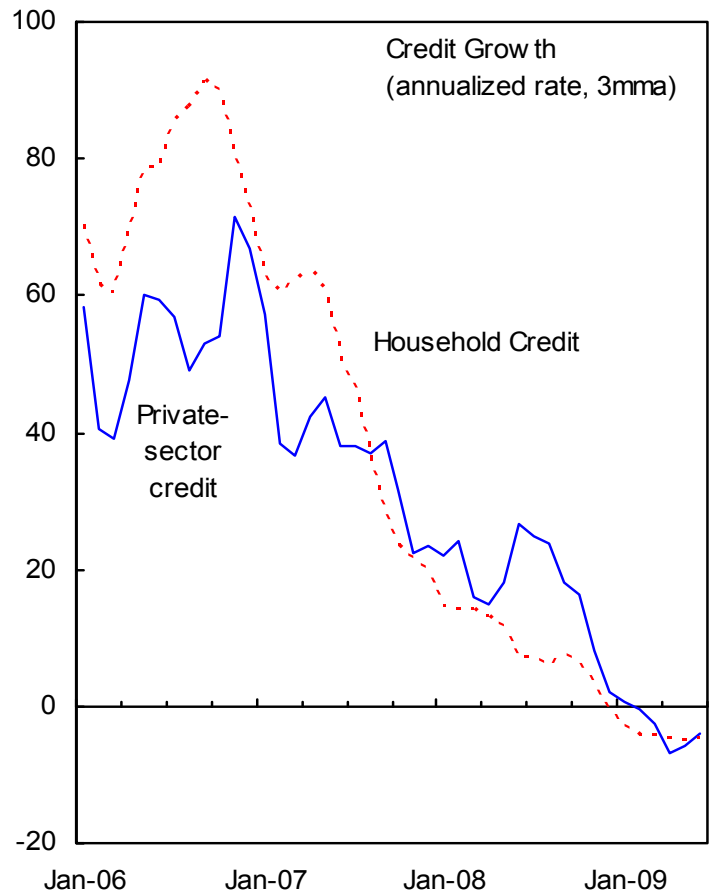

Most of the lending has been related to real estate

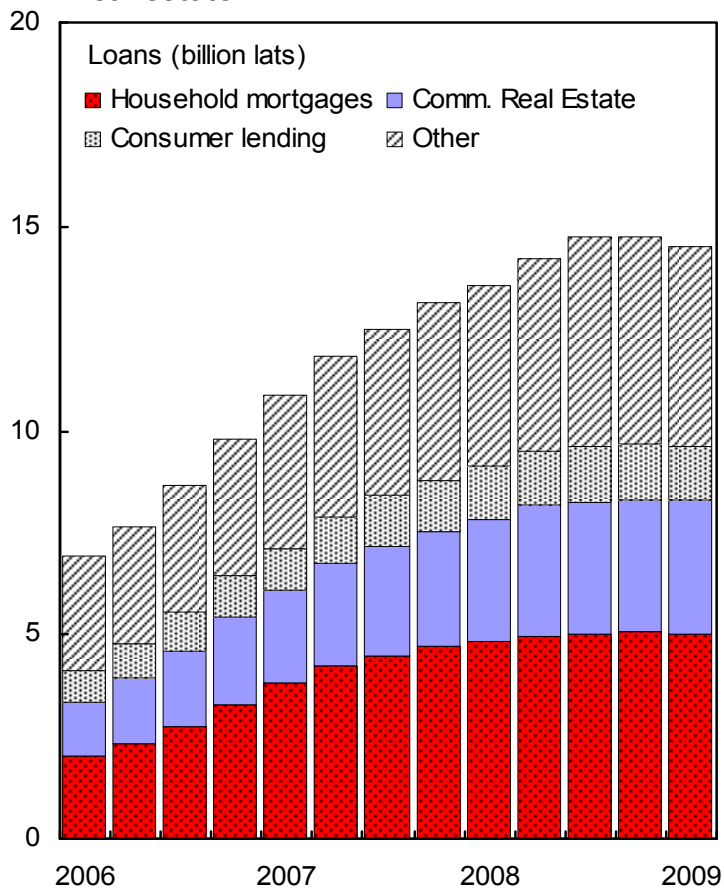

Source: Latvian Authorities, Fund Staff Calculations. 
- While euro loan and deposit rates have fallen in line with ECB rates, interest rates on lats loans and deposits have increased sharply (Figure 5), reflecting the credit crunch but also uncertainty over the exchange rate. Despite the widening rate differential, lats deposits have fallen 15 percent since the end of last year, while euro deposits have increased 15 percent. Total resident deposits were stable for most of the year, though fell around 2 percent in July.

- $\quad$ Base money has fallen by one quarter since the end of last year, both currency in circulation ( in part reflecting collapsing economic activity) and bank reserves (due to lower reserve requirements and declining non-resident deposits, on which banks must hold lats reserves). Net reserves have fallen even faster, as NDA rose as the Treasury drew down international financial assistance (Figure 6). However, NDA is well below program projections, because the program included a buffer in case of capital outflows or if large-scale support to the banking system were needed (Tables 2-3).

9. Fiscal deficits have risen above program targets reflecting both the sharperthan-expected downturn and weak program implementation (Figure 7):

- The government missed the end-December 2008 performance criterion for the adjusted fiscal deficit by $1 / 2$ percent of GDP, the end-March by $1 / 4$ percent of GDP, and the end-June indicative target by an estimated 1 percent of GDP. This reflects the adverse economic conditions and overruns in the central government deficit. Local governments on the other hand abstained from expected expenditure increases ahead of the municipal elections.

- The program's fiscal measures were only partly implemented. Although all the December budget tax increases (about 2 $\frac{1}{2}$ percent of GDP) were introduced, only around one third of the $4 \frac{1}{2}$ percent of GDP in expenditure cuts appear to have been implemented. Significant cuts were instead made on mandated expenditure including EU-financed spending and transfers to local governments, which will later need to be reversed. Pension expenditure was also underestimated.

- $\quad$ Public wages were, in general, only slightly reduced (although bonuses were removed), while monthly wages below L360 (€500) per month (the bulk of local government wages) were protected by law from wage cuts. As a result, indicative wage-bill targets for end-December, end-March and end-June were also missed.

- Across-the-board cuts have created arrears, leading to nonobservance of a continuous performance criterion. The authorities also newly disclosed the existence of two extra-budgetary funds (one subsequently liquidated; the other suspended for the duration of the program), which breached a statement at the start of the program that no such funds existed. 
Figure 5. Latvia: Interest Rates and Euroization, 2006-09

Deposit and lending rates in euros have fallen in line with Euribor, while rates in lats have risen sharply, in part due to market concerns about the exchange rate...
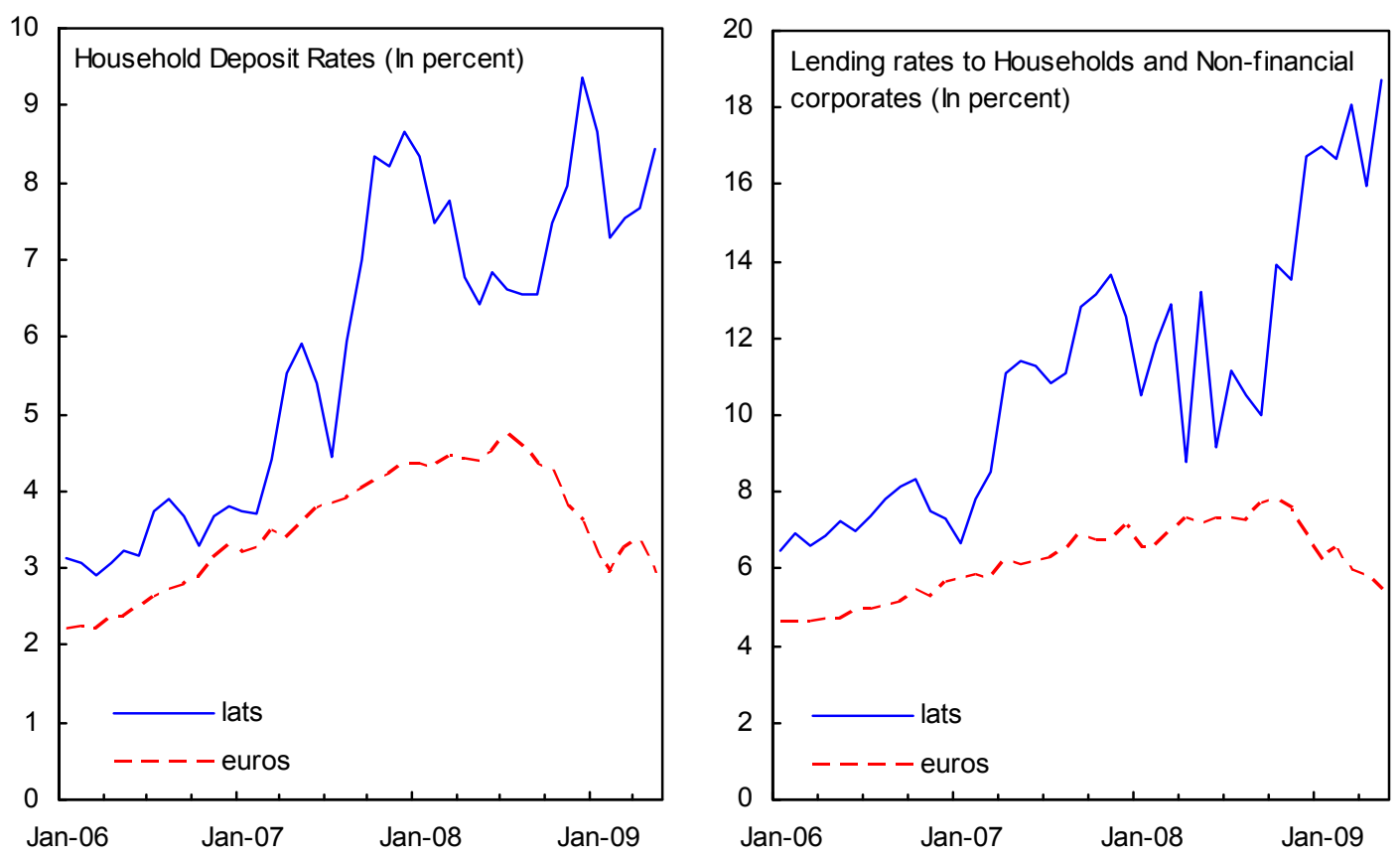

...contributing to rising euroization of the deposit base, while the bulk of loans are in euros.
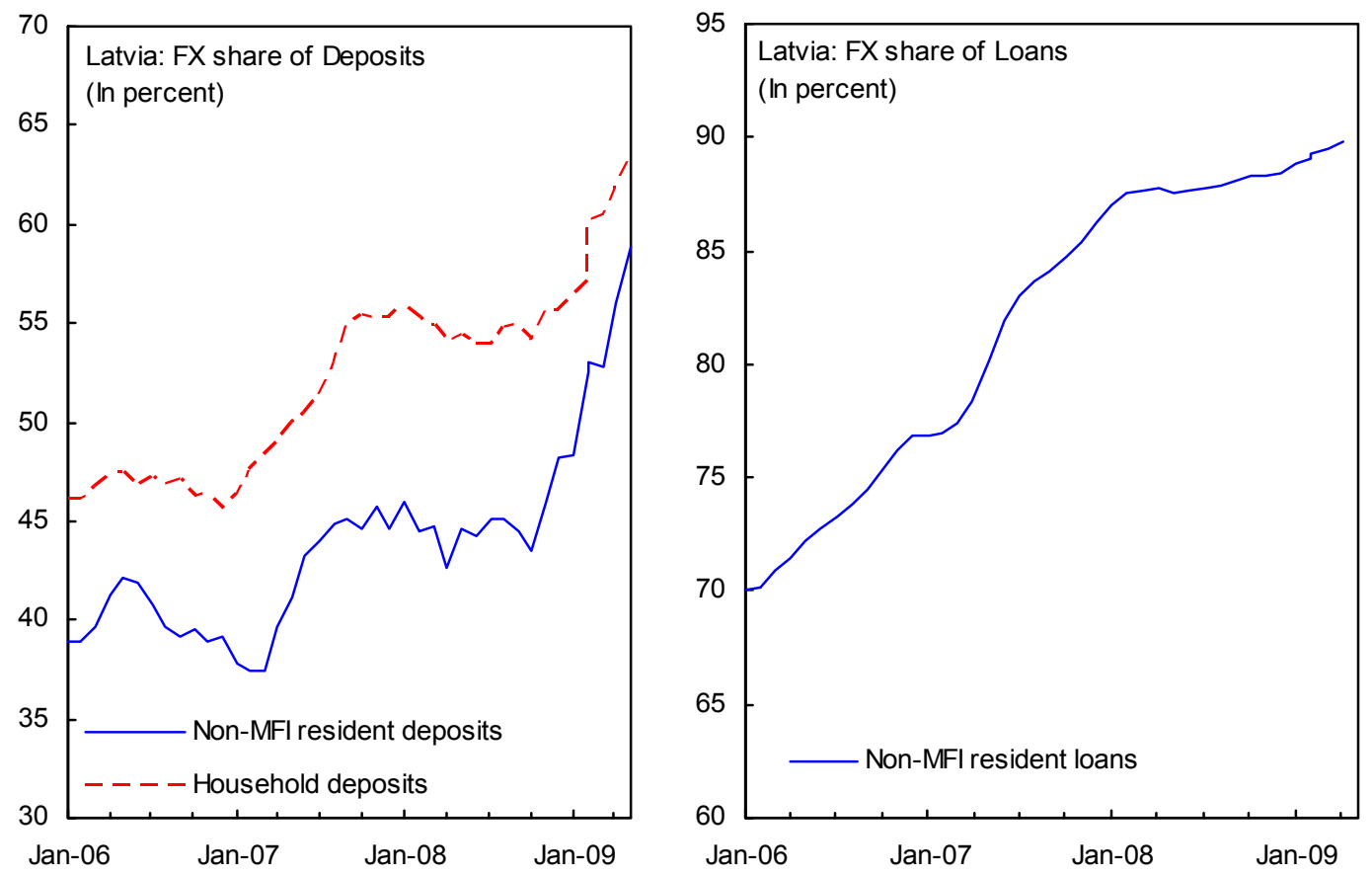

Source: Bank of Latvia 
Figure 6. Latvia: Base Money and BoL's Net Domestic Assets, 2008-09

Lats in circulation have fallen more than 20 percent since the beginning of the year

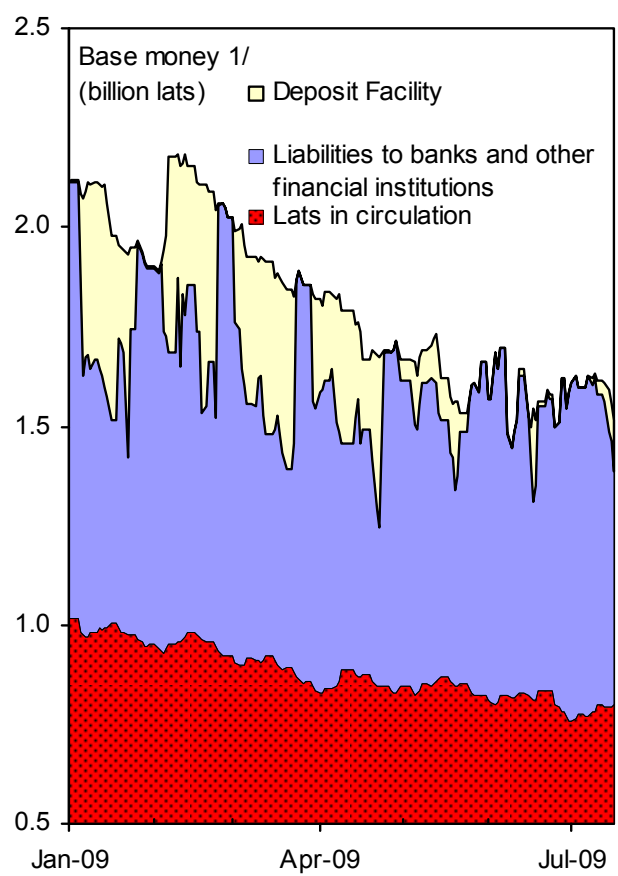

The authorities have easily met their NDA targets

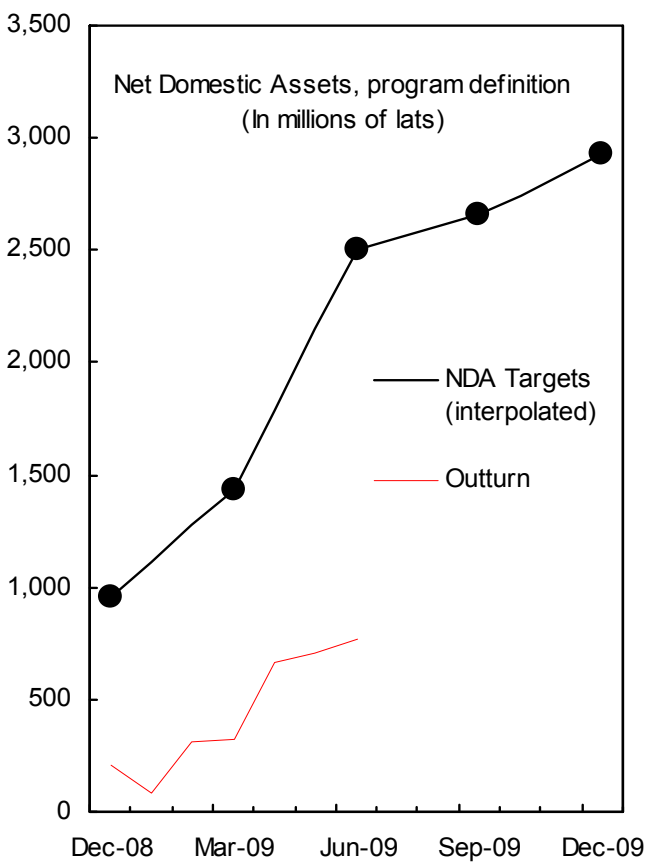

Reserves fell faster than base money as NDA increased.

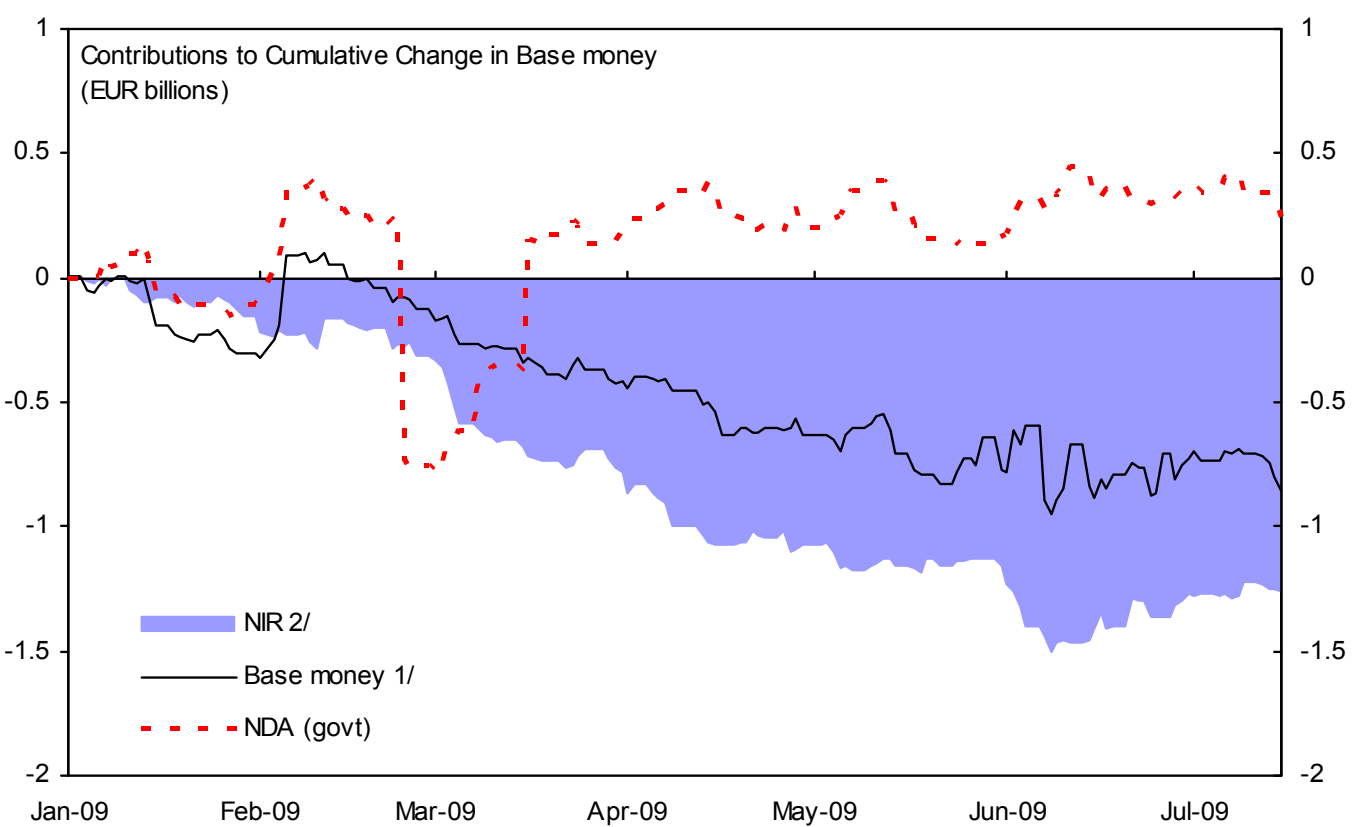

Source: Latvian Authorities, Fund Staff Calculations.

1/ A broad measure of base money that adds outstandings on the deposit facility to the Bank of Latvia's definition of base money (lats in circulation, banks' required and excess reserves, and liabilities to other financial institutions).

2/ Adjusted for Parex-related transactions. 
Figure 7. Latvia: Fiscal Sector, 2005-09

The general government fiscal balance is steadily deteriorating...

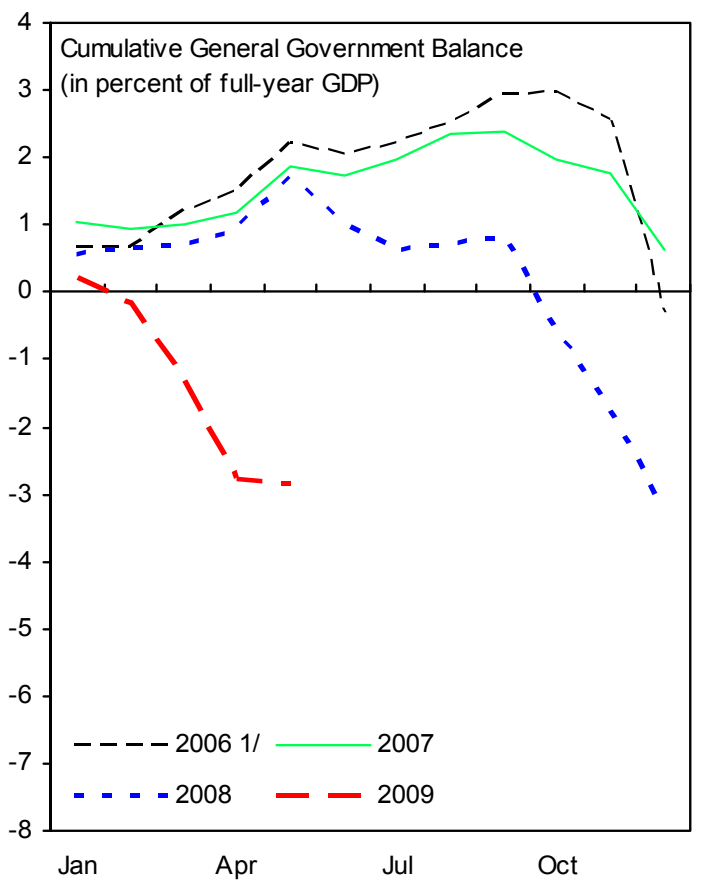

Expenditures have not fallen as much as planned...

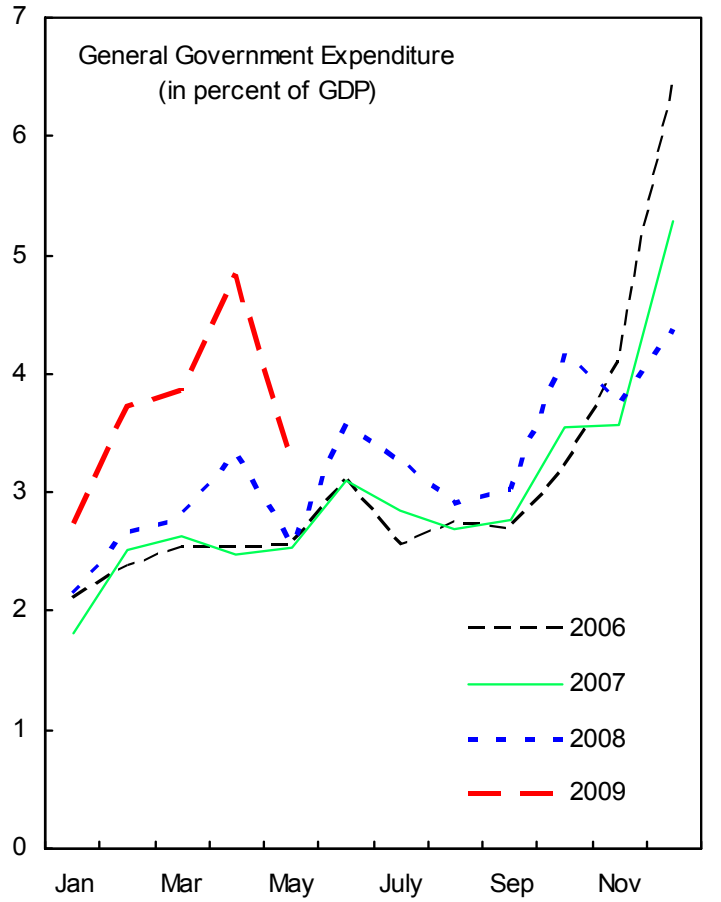

... as indirect taxes are collapsing, despite tax increases at the start of the year

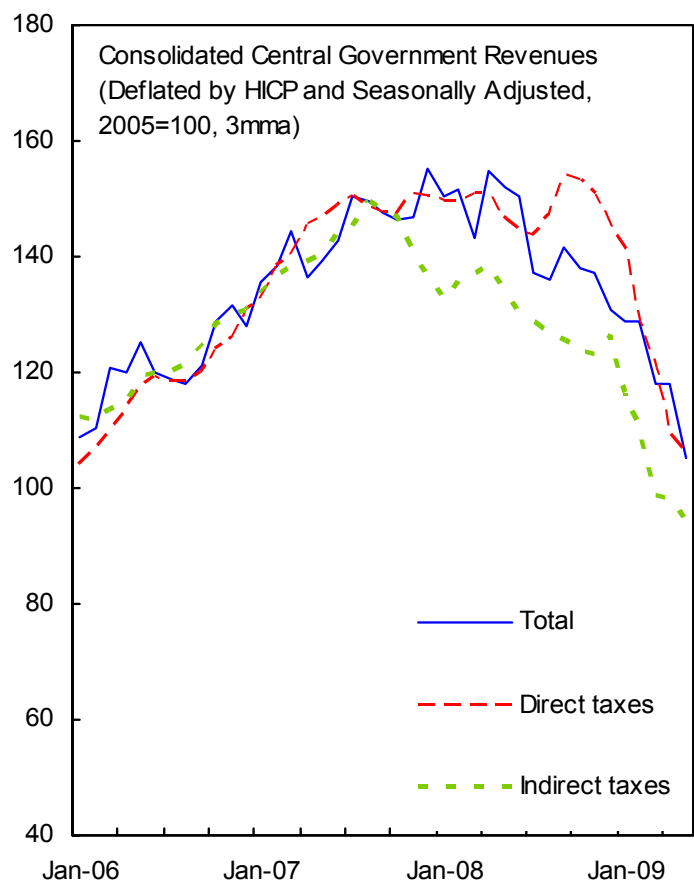

....and pensions have continued to increase

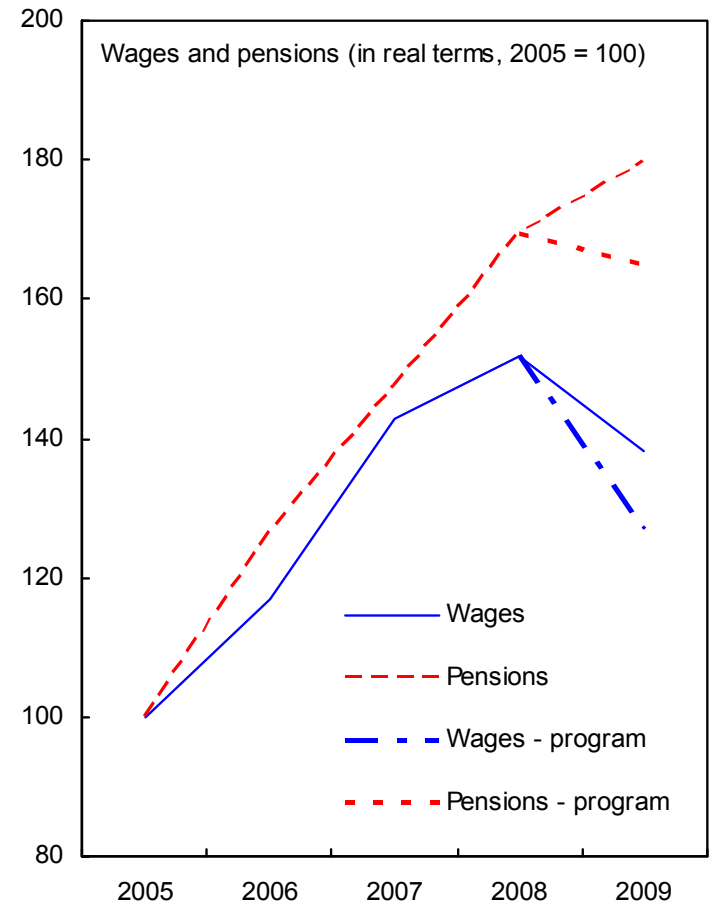

Source: Fund Staff estimates and calculations. $1 / 2006$ is based on a different budget classification than the more recent years. 
- $\quad$ The structural performance criterion on submitting a fully-fledged supplementary budget to parliament by end-March was not met, though in part this delay reflected the fall in February of the previous government.

10. Reflecting the output collapse, tax revenues have fallen sharply since the beginning of 2009. VAT receipts fell 30 percent year on year in the first half of the year, despite the increase in the VAT rate from 18 to 21 percent and the removal of most exemptions, because of the collapse in domestic demand and drawdown of a large overhang of VAT refunds accumulated during the boom years (2-4 percentage points of GDP). Compliance has also deteriorated. Direct taxes have been more robust, which may reflect lower than projected declines in officially recorded wages and the tendency of corporate income tax payments to lag corporate profits.

11. General government expenditure remains broadly in line with program projections, with slippages in the central government offset by temporary restraint by local governments:

- $\quad$ Pension spending increased 32 percent year on year in the first half; it will rise from 6 percent of GDP in 2005 to a projected 9 percent of GDP this year.

- The public sector wage bill remains high: it fell almost 5 percent in the first half of the year, whereas the program had assumed a 35 percent contraction.

- The authorities recapitalized the state-owned Mortgage and Land Bank in January, creating unbudgeted above-the-line costs of $1 / 4$ percent of GDP, and (subject to EC approval) intend to convert EU funds deposited in the bank (a further $1 / 4$ percent of GDP) to further increase equity.

- Spending in the first half of the year was temporarily depressed by a ban-since lifted — on local governments signing project contracts that extend into 2010.

12. Because of the downturn (and despite the appreciation of the real exchange rate) the current account has moved into surplus (Figure 8). Exports have fallen because of the decline in world demand. But this has been more than offset by a collapse in imports, which fell nearly 40 percent year-on-year in the first quarter of 2009. In addition, Latvia's income account has returned to surplus as the profits of foreign-owned firms evaporated. As a result, the current account ran a $€ 370$ million ( 2 percent of annual GDP) surplus through May.

13. However, the capital account has weakened considerably:

- Domestically owned banks have made larger loan repayments than expected. As part of the restructuring of $€ 775$ million of syndicated loans, Parex's external creditors were paid $€ 232$ million in March. 
Figure 8. Latvia: Balance of Payments, 2008-09

Imports have fallen much more rapidly than exports...

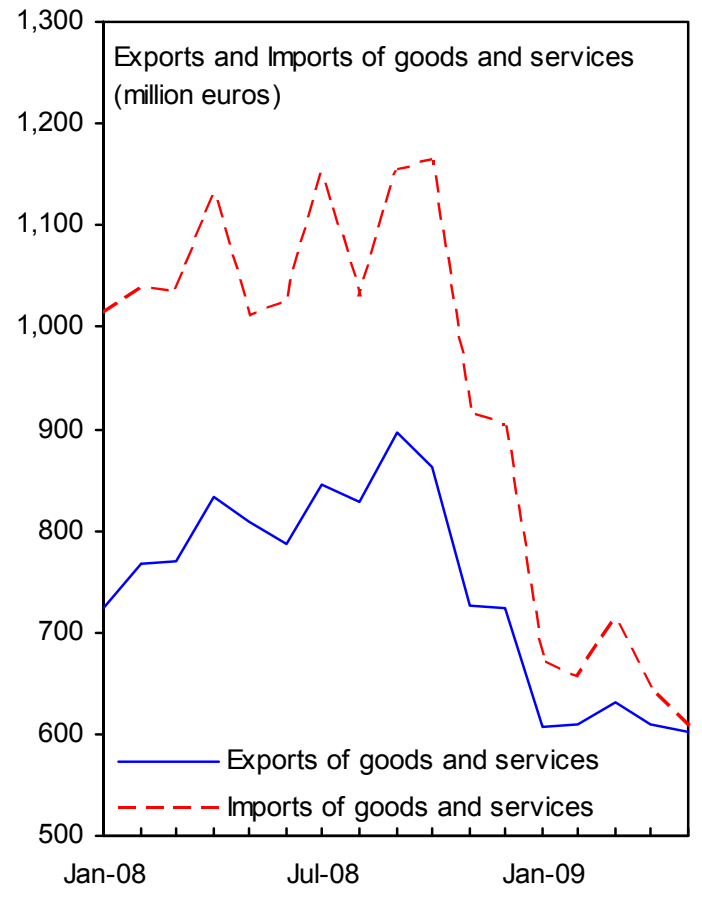

Financial account outflows remain intense.

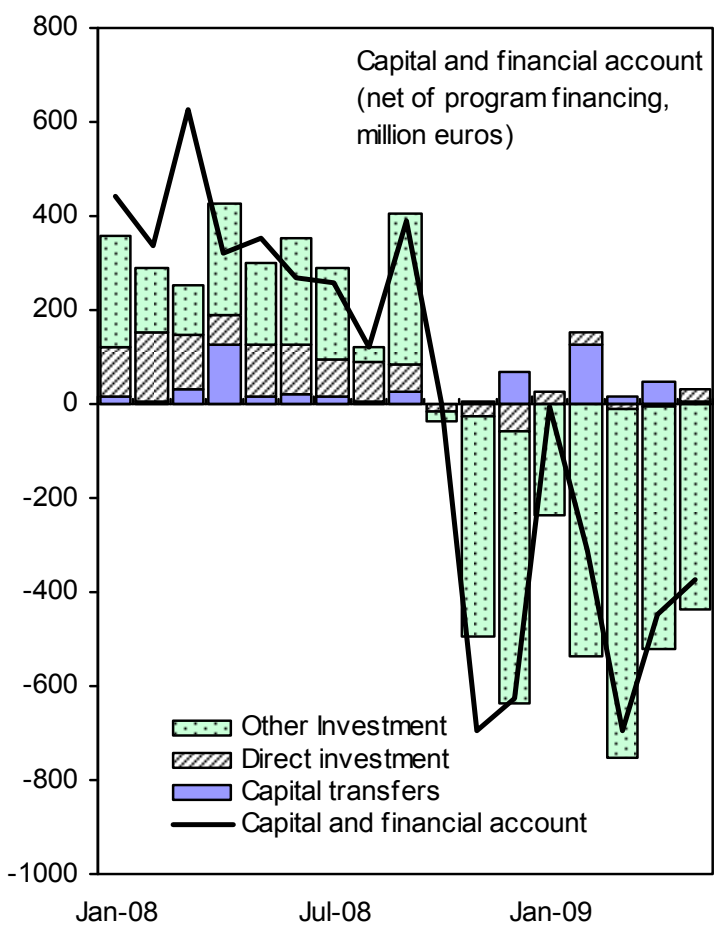

...leading to substantial current account surpluses during the first half of this year

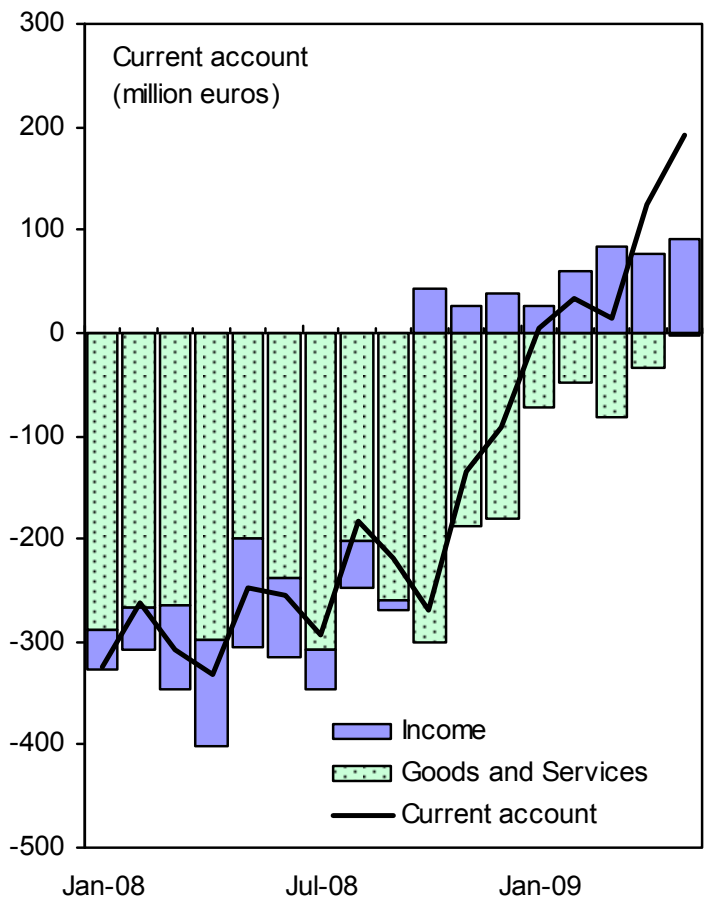

... in part due to nonresident deposit outflows

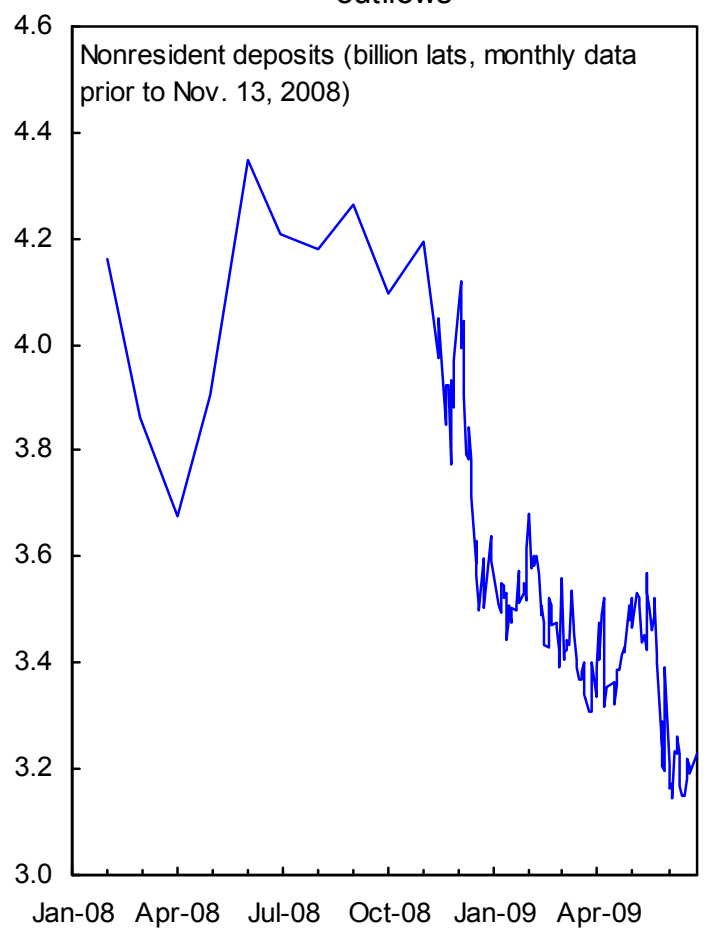

Source: Bank of Latvia and staff calculations. 
- $\quad$ The maturity extension (only to 2011) with expected full repayment implies a lower rollover rate than assumed over the program period. Other local banks have been unable to roll over syndicated loans, even though the government was ready, in some cases, to offer guarantees on new liabilities, implying considerably larger outflows than under the program (which had assumed 40 percent rollover).

- $\quad$ Some foreign banks have lowered exposure to their Latvian subsidiaries (see paragraph 8).

- $\quad$ Nonresident deposit outflows have continued, on the whole at a much slower pace than the crisis last November-December, though rapid at times.

- $\quad$ Residents have also begun to accumulate assets abroad-rebuilding buffers dented at the height of the crisis, though also reflecting some loss of confidence in the lats.

14. Amid all these uncertainties - the deeper downturn, loss of confidence in the lats, growing fiscal deficit-Latvia's exchange rate peg has faced waves of heavy pressure (Figure 9).

- $\quad$ Since end-December, gross international reserves have fallen more than $\mathbf{2 5}$ percent to $€ \mathbf{2 . 9}$ billion; net international reserves have fallen by $€ 1$. 6 billion.

- In part these outflows were caused by December's reduction in reserve requirements, and Treasury's sale of foreign exchange to finance the deficit. Responding to Fund staff advice to tighten monetary policy and better manage liquidity, from March the Treasury began treasury bill sales - in part financing the deficit - and this helped slow the reserve loss.

- But the outflows also have more fundamental causes: the deteriorating economic outlook, repayment of loans from foreign parent banks, and increased demand for foreign currency deposits (and lower demand for lats deposits and base money).

- Numerous shocks have also caused instability, including political uncertainty (February's collapse of the Godmanis government; June local elections), press reports of possible devaluation (most notably, statements by a former Riksbank governor and senior Latvian politicians), and the shock effect of a failed treasury bill auction in May (which was caused more by simple lack of lats liquidity than devaluation risk).

- As a result of these shocks, by end-May interest rates had increased sharplyrates on BoL instruments reached close to 80 percent - and the peg was successfully defended. 
Figure 9: Latvia: Net international reserves and FX market developments

NIR has fallen steadily following FX sales by the State Treasury and the BoL
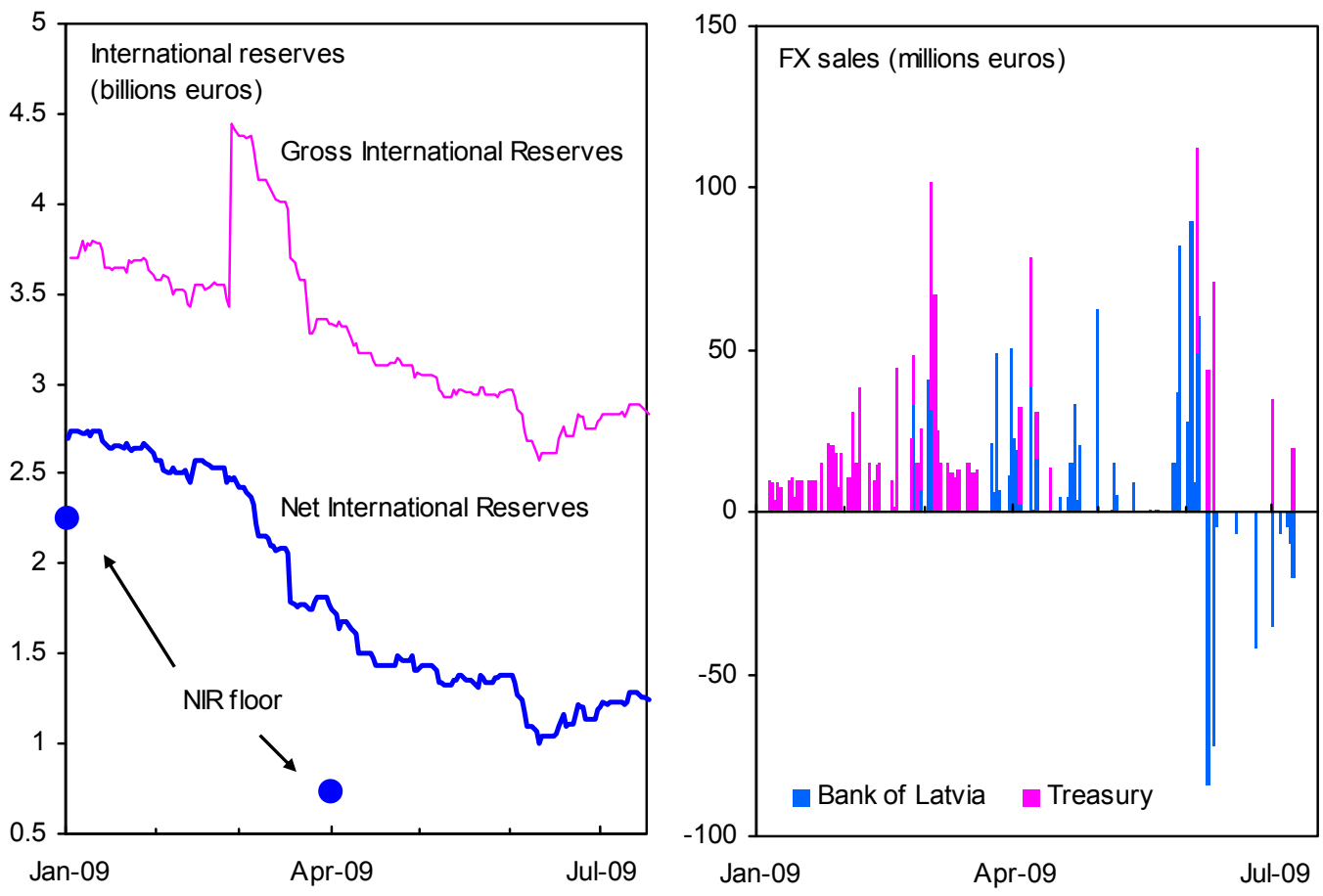

As lats liquidity tightened, the lats moved into the appreciated end of the band...

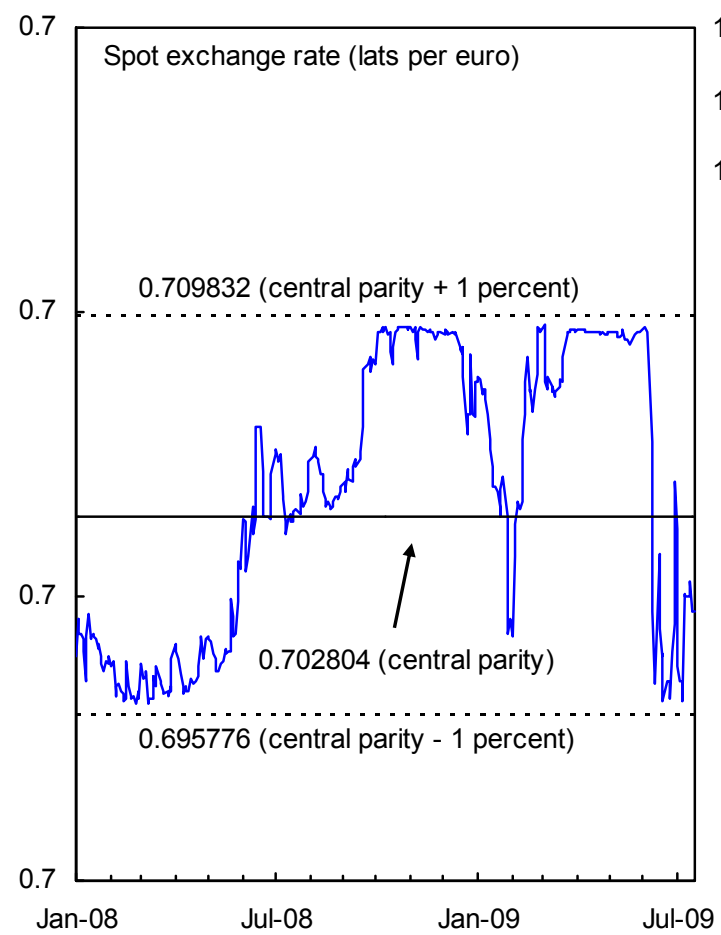

...but CDS spreads remain elevated

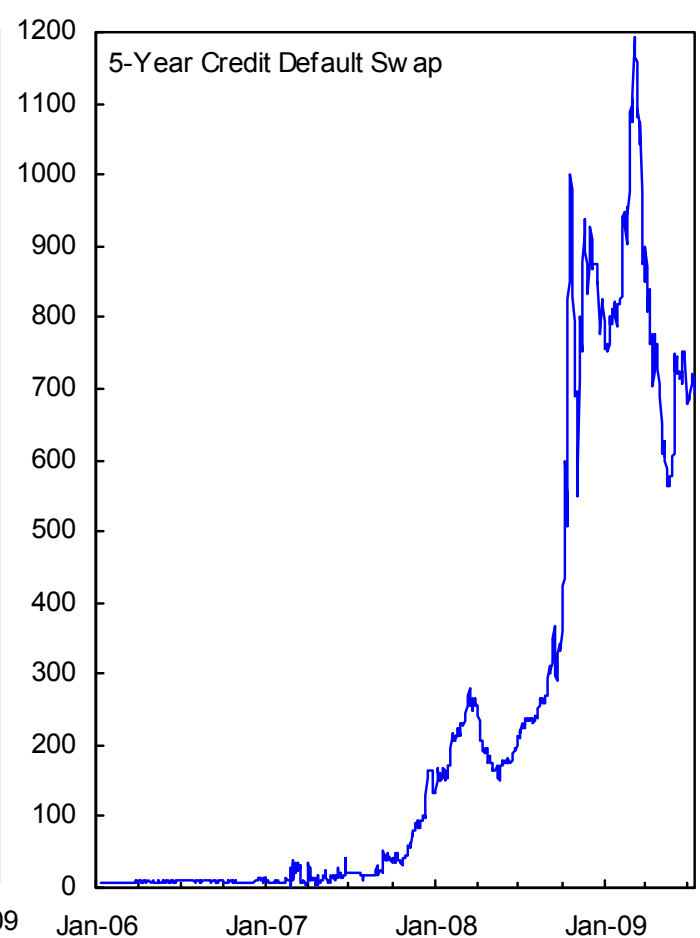

Source: Bank of Latvia. 
- $\quad$ Following the announcement in June of an imminent $€ 1.2$ billion European Union disbursement, pressures eased considerably. The lats appreciated within the band and the central bank started to buy foreign exchange. However, forward foreign exchange rates remain high, as do CDS spreads, implying concerns over the stability of the peg as well as sustainability of the government debt.

15. The banking sector is suffering strains caused by the downturn, lower real estate prices and global deleveraging (Figure 10, Table 4):

- A large proportion of household mortgages have negative equity (more than 50 percent of the portfolio of the largest bank) and the share of loans reported to be at least 90 days overdue has risen above 10 percent. The need to provision for bad loans has caused system-wide losses at an annualized rate exceeding 2 percent of GDP.

- However, the FCMC reports that the banking system is adequately capitalized at present, with a system-wide capital-adequacy ratio (CAR) of 13 percent in May. Earlier this year the FCMC sought written undertakings from the parents of the major foreign banks that they will maintain adequate capitalization and liquidity of subsidiaries. Focused examination of the banking sector by external auditors has been completed at the end of March (structural benchmark) suggesting no immediate solvency issues.

- The legal framework for bank intervention and deposit insurance has been significantly strengthened in line with requirements of the end-June structural benchmark.

\section{Policy Discussions}

16. The program needs to be readjusted to the changed economic conditions. In responding to these challenges, the Latvian authorities have stressed the need to respect their EU and ERM2 membership commitments. Discussions focused on:

- $\quad$ Revising the macroeconomic outlook, in light of the much deeper downturn.

- $\quad$ Reassessing the fiscal deficit projections for 2009 and the medium-term, evaluating the size of adjustment needed to safeguard debt sustainability, and developing specific measures that would generate this adjustment.

- $\quad$ Further steps to stabilize the financial system, including strengthening Parex, developing a new business model for the state-owned Mortgage and Land Bank, and promoting recapitalization more generally.

- Within the constraints posed by the peg, the case for using monetary policy to reduce volatility in lats liquidity.

Staff from the World Bank, Swedish authorities, European Central Bank and, especially, the European Commission, played an active role in the discussions. 
Figure 10. Banking Sector Profitability and Solvency, 2006-09

Overdue loans are rising sharply...

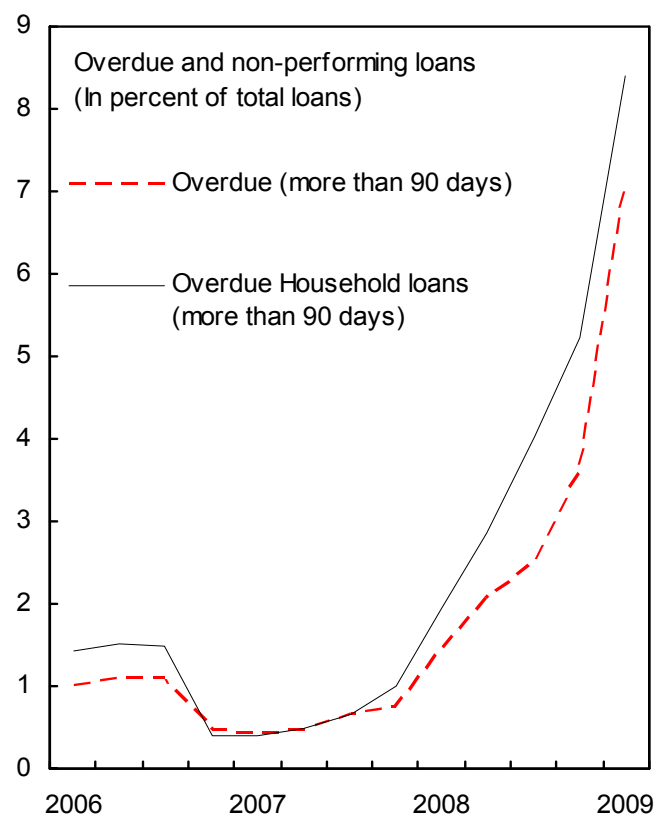

...due to the deterioration in the real-estate market

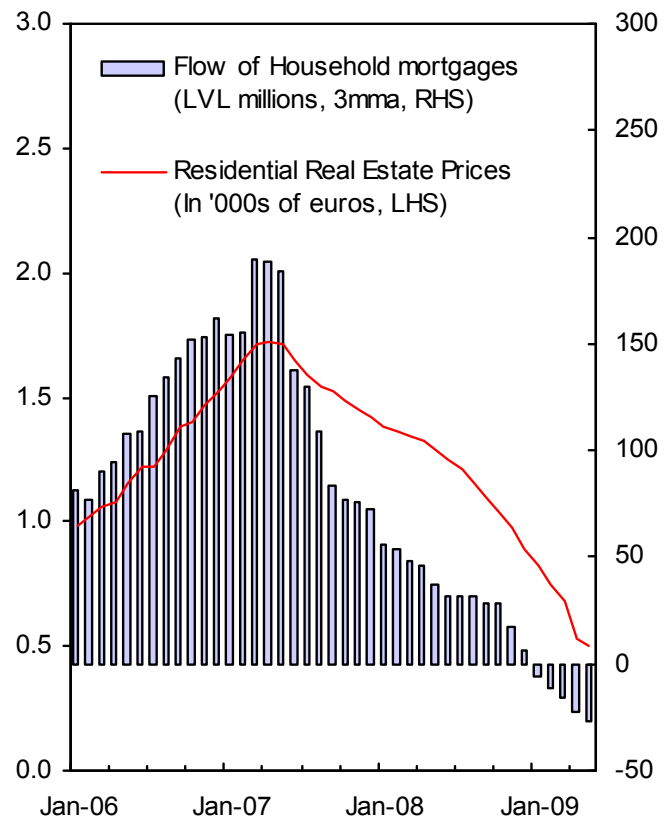

...which will further erode bank capital

Banks are already making large losses...

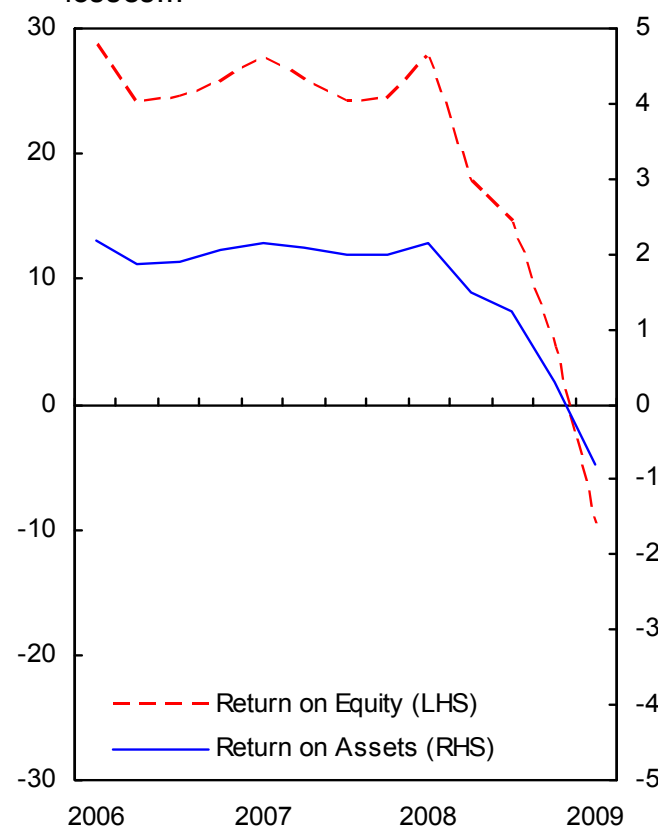

Sources: FCMC, Bank of Latvia, Latio real estate broker, Arco, Oberhaus and Fund Staff Calculations.

1/ Banks (mainly foreign owned) dealing primarily with Latvian residents.

2/ Banks dealing primarily with non-residents of Latvia. 


\section{A. Macroeconomic Framework}

17. Latvia is experiencing a severe contraction in output, comparable to the transition recession of the early 1990s (LOI $17-9$, Table 5):

- Staff and the authorities project an 18 percent fall in GDP this year. This decline is among the most severe in the world, and the cumulative output decline exceeds that of the Asian countries in 1998-99. Although some indicators suggest a milder decline in the second quarter, activity is projected to fall further in the second half of the year given expected spending cuts and tax increases in the supplementary budget.

- The downturn is projected to continue until the second half of next year.

Additional measures needed to reduce the 2010 fiscal deficit, lagged effects of real appreciation and continued deleveraging by foreign banks will likely cause continued demand weakness through early 2010. The economy is expected to stabilize in the third quarter, as the major European economies recover. Nevertheless, due to the base effects of declines in late 2009, GDP is still projected to fall on average by 4 percent in 2010 (in line with the consensus forecast). From peak-to-trough, the level of output is projected to fall by close to 30 percent.

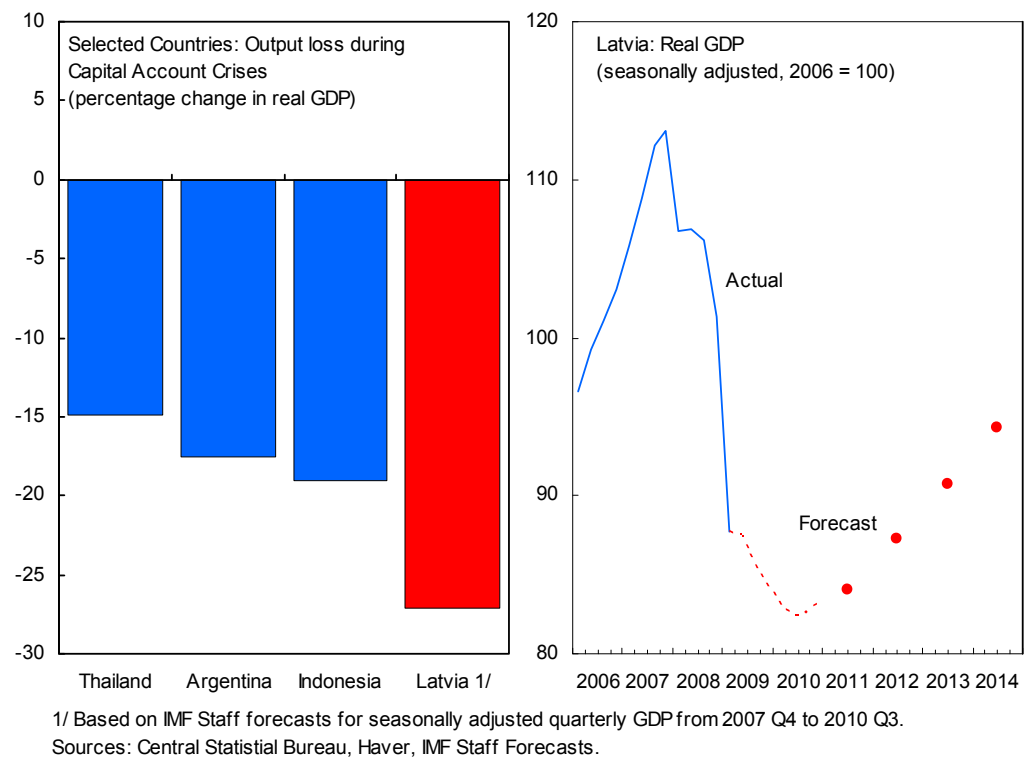

- $\quad$ Recovery is likely to be slow. Declines in real estate, financial services, and other non-tradable activities are likely to be permanent, consistent with a fall in the level of potential output (Box 1). It will take time before Latvia becomes cost competitive enough to attract investors into manufacturing and other tradable sectors. The authorities argued that the staff's medium-term projections were overly pessimistic, especially if the global economy were to recover more strongly than anticipated. In 
contrast, while accepting the staff projections, EC officials noted the downside risks to output due to fiscal restraint through 2012.

- The projected downturn has raised unemployment substantially (straining Latvia's social safety net) and will likely lead to continued deflation. More than 10 percent of employees, including 20-30 percent of those in central government administration, are expected to lose their jobs through 2011. Unemployment is forecast to peak in 2010 at around 18 percent (labor force survey), but could exceed this if the European recession is prolonged and migration opportunities dry up. The slack labor market, nominal wage cuts, and a large negative output gap are expected to cause mild but prolonged deflation: consumer prices are forecast to fall by a cumulative 8 percent through 2011, though an even sharper fall is possible (Box 2).

- Macroeconomic projections are subject to greater than usual uncertainty, given the extent of the downturn, and alternative possibilities of continued downturn (as fiscal adjustment and credit reduction feed upon themselves) or a more robust recovery if the world economy, especially the EU, were to turn around. However, under either scenario, the decline in output is likely to be permanent and substantial.

18. The current account surplus is expected to widen to 41/2 percent of GDP in 2009 and remain in surplus (Table 6). This is a large deviation from the original program projection of a 7 percent of GDP deficit for 2009, followed by moderate deficits. Imports have been lowered in line with the sharp falls in domestic demand-despite the widening of the budget deficit - and some projected improvement in competitiveness in later years. The income account moves into surplus in 2009-10 due to losses at foreign-owned banks and real estate companies, but returns to deficit from 2011 as interest rates increase and the foreign-owned sector makes profits again.

\section{However, capital outflows are projected to remain strong, contributing to} continuing balance of payments pressures (Tables 7,8 and 9):

- Domestic banks are now projected to have to repay most of their external liabilities falling due in 2009 and 2010. Rollover rates on maturing syndicated loans are expected to be zero for state-owned banks, and 30 percent in 2009 and 50 percent in 2010 for other domestic banks. Non-residents are projected to repatriate a further 35 percent of their deposits through end-2010, an outflow of about $€ 1.5$ billion.

- Foreign-owned banks' domestic assets are forecast to shrink as loan amortizations exceed new lending, enabling them to repay liabilities to their parents. However, consistent with their earlier commitments, a number of foreign banks intend to recapitalize their subsidiaries, and there will be partly offsetting foreign direct investment inflows exceeding $€ 400$ million this year.

- Impact of non-performing loan provisioning. Steady write-downs of euro-denominated loans are worsening banks' net open FX positions, which banks have to offset by acquiring FX assets or reducing their FX liabilities (including, in the 
case of foreign-owned banks, by repaying loans to their parents). This causes a drain on reserves, but issuance of euro-denominated assets by the government could counter this (see below).

- Capital flight. Residents have already begun to hedge the risk of a devaluation by lowering the domestic currency share of their portfolios. They will likely continue to exchange most of the lats created by the budget deficit into foreign exchange or offshore financial assets, causing a steady drain on reserves.

- $\quad$ About half of all Program Financing has been provided so far, although disbursements have been pushed back about three months. The Riksbank swap line was renewed in March though is not being used, and the EC disbursed $€ 1.2$ billion at end-July. Disbursements are expected soon from the EBRD (€100 million investment in Parex) and the Czech Republic (€200 million loan), followed by the World Bank in September, and Nordic countries in early 2010.

20. With the sharp fall in nominal GDP over the next 2 years, the external debt to GDP is projected to increase sharply to 175 percent in 2011 (from 127 percent at end2008) before declining over the medium-term. Debt dynamics are driven mostly by the denominator effect, with the increase in public external debt offsetting a decline in private sector debt - while current account surpluses allow a further accumulation of foreign assets and decrease in net external debt, as the economy builds external buffers.

\section{B. Fiscal Policy}

21. Latvia's fiscal position faces extreme challenges. Before June's supplementary budget, staff had estimated a baseline fiscal deficit this year of around 16 percent of GDP compared to 3.3 percent in $2008 .^{2}$ This reflects in large part a structural deficit, caused by very rapid spending growth during the 2004-07 boom, now both revealed and compounded by a collapse in tax revenues and an increase in social spending due to the severe downturn. For 2010, IMF staff estimate the baseline deficit (prior to the effects of the 2009 supplementary budget) would have deteriorated by as much as 8 percent of GDP to 24 percent of GDP (Table 10). ${ }^{3}$ Double-digit fiscal deficits cannot be continued for any

\footnotetext{
${ }^{2}$ IMF staff projections exclude from revenue second-pillar pension contributions that have been diverted to the budget to pay current pensions. The Latvian authorities did not prepare their own baseline deficit estimates that illustrated the expected impact of the supplementary budget.

${ }^{3}$ The deterioration in the baseline reflects (i) higher interest payments; (ii) lower corporate income tax revenues as many firms suffer losses; (iii) the full-year effect of the contraction in wage and consumption-based taxes; and (iv) denominator effects (combined with rigidities in nominal expenditure) automatically increasing expenditure as a share of GDP. Government spending is roughly 50 percent of GDP; if nominal GDP falls 8 percent (4 percent real plus 4 percent GDP deflator) as projected, then, holding nominal spending constant, the spending ratio (and the budget deficit) automatically increases by 4 percent of GDP.
} 
length of time without exceeding Latvia's financing sources, and setting debt on an unsustainable path.

Latvia: Impact of the June 2009 Supplementary Budget and Measures Required in 2010 to Meet the Program's Deficit Target

(Staff projections)

\begin{tabular}{lccr}
\hline & 2008 & 2009 & $\mathbf{2 0 1 0}$ \\
\hline & & (in percent & \\
& & & \\
& & & \\
& & -16.0 & -23.9 \\
Baseline deficit 1/ before 2009 measures & $\ldots$ & +3.4 & +6.5 \\
2009 measures & $\ldots$ & +0.5 & $\ldots$ \\
Partial reallocation of net lending on s.s. nets & $\ldots$ & -1.0 & -1.0 \\
Additional social safety nets & $\ldots$ & -13.0 & -18.4 \\
Deficit 1/ after 2009 measures & -3.3 & -13.0 & -12.0 \\
Deficit target 1/ 2/ & $\ldots$ & $\ldots$ & -6.4 \\
Gap/Additional measures needed & & & \\
\hline
\end{tabular}

1/ Basic fiscal balance, or general government net borrowing requirement excluding bank restructuring costs.

2/ Actual outturn for 2008.

Sources: Latvian Authorities, and IMF staff estimates.

\section{The 2009 Supplementary Budget}

\section{Against this background, a significant revision of the 2009 fiscal program was}

needed. On one hand, credible action was needed to begin to address the structural fiscal challenges, especially in light of the authorities' chosen strategy of keeping the exchange rate peg. On the other hand, there was a need to recognize the severe effects of the downturn and to limit social costs, particularly for the most vulnerable. In the original program, the authorities had committed to adopt a supplementary budget by end-March, which would replace December's across-the-board cuts with measures based on more lasting structural reforms. Following delays due to the change in government, IMF technical assistance missions visited Riga in April and May to assist the authorities with their preparations. The government took time to respond, but acted after June's European and municipal elections, passing a supplementary budget quickly. However, this budget did not incorporate suggested improvements from Fund staff. Main elements include (LOI $\llbracket 12$ ):

- Significant expenditure cuts and some revenue measures. However, many of these are either one-off or across-the-board, while structural reforms are more modest (Box 3). The most permanent measures include: (i) reductions in PIT allowances, increased excise duty, and cuts in social subsidies (full-year savings of 1 percent of GDP); and (ii) nominal pension cuts ( $3 / 4$ percent of GDP) comprising 10 percent for most pensioners (two-thirds of savings) but 70 percent for those in employment 
(one-third of savings); however, both these are being challenged in the Constitutional Court. $^{4}$

- Expansionary measures: increases in net lending and government assumption of existing debt, a 50 percent increase in guarantees, and higher spending commitments for 2010-11 will be expansionary. In addition, abolition of the 1.8 percent of GDP of resources held in the contingency reserve (overriding a program commitment to retain a 5 percent reserve), will make it harder for the Ministry of Finance to exercise control in the case of spending pressures.

23. Taken together, the impact on the 2009 budget deficit is difficult to predict: ${ }^{5}$

- Two factors could cause budget overruns. First, as discussed below, mandated social spending appears to be under-budgeted, suggesting that the across-the-board cuts are unlikely to be fully implemented. Second, while abolishing the contingency reserve, the budget also gives the Finance Minister powers to increase spending in exceptional circumstances (subject only to cabinet and Parliamentary budget committee approval), increasing the risk of budgetary overruns.

- However, the Ministry of Finance may ration cash to restrain the deficit. This would probably lead to arrears or unsustainable cuts (for example in EU-financed projects, for which funds have already been received without the spending taking place), putting greater pressure on the 2010 deficit.

24. Staff also cautioned that the across-the-board cuts could impair the quality of public services, create additional future costs and weaken public-sector institutions. Moreover, the burden of the supplementary budget also falls disproportionately on the poor. (Box 4)

25. These concerns created a conundrum. On the one hand, resolute and sustained fiscal adjustment is essential to safeguard sustainability and to protect the fixed exchange rate strategy. On the other hand, the supplementary budget contains few of the structural reforms needed for sustainable adjustment.

\section{On balance staff argued for allowing a slightly higher budget deficit in $\mathbf{2 0 0 9}$ to} protect basic services and to rebalance the burden of adjustment, while preparing for

\footnotetext{
${ }^{4}$ The relevant pension law needs to be reviewed every six months by the Cabinet of Ministers, and expires in 2012.

${ }^{5}$ Fiscal estimates are subject to considerable uncertainty. Latvia's public financial management institutions are weak, the role of the Ministry of Finance in the preparation of the budget is limited, and the link between the cash budget and policy decisions is tenuous. In particular, the Ministry of Finance relies on line ministries to estimate the full-year impact of the budget, and has little control over expenditure commitments.
} 
structurally sound adjustment in 2010 (LOI $\mid 13-14)$. The program therefore allows a higher 2009 deficit (of up to 13 percent of GDP) so that the most socially painful measures in the supplementary budget can be reversed. The higher 2009 target also includes adequate funding of capital spending, EU-financed expenditure, existing social safety nets (such as GMI). Following these adjustments, the 2009 effect of the new measures is estimated at $3 \frac{1}{2}$ percent of GDP, or $6 \frac{1}{2}$ percent for the full year 2010 (Table 11). One percentage point of GDP would be provided for additional social safety nets. It would be financed within the existing international financing package. Given the additional room now provided under the program, staff urged the authorities to work closely with the World Bank to develop an emergency social safety net package, which would help alleviate the social costs of rising poverty and joblessness.

27. The authorities are also taking new steps to minimize fiscal risks ( $(15-17)$. They are limiting ministries' abilities to commit to new spending (including not launching any new PPPs this year, except for new kindergarten facilities, nor new net lending except to local governments), capping new public guarantees, and strengthening the powers and technical capacities of the Ministry of Finance. These steps should help the authorities control the deficit and limit the accumulation of arrears. Substantial technical assistance from FAD and other institutions should help the authorities achieve these goals.

\section{Medium-term Fiscal Path}

28. The recommendations of ECOFIN to Latvia in its discussion of Latvia's "excessive deficit" was for an annual fiscal effort of at least $23 / 4$ percentage points of GDP and deficits of 8.5 percent of GDP in 2010, 6 percent in 2011 and 3 percent in 2012 (on ESA terms). ${ }^{6}$ The deficits recommended by ECOFIN represent Latvia's commitment to the EC in the context of the latter's financial assistance. Provided these targets can be reached, this could resolve Latvia's fiscal and external vulnerabilities. However, there are important risks. First, even under this "rapid adjustment" scenario, staff projects that government debt would exceed 55 percent of GDP by 2012 (Figure 11, Tables 12-13). Adding in bank restructuring costs (which are difficult to estimate), the debt ratio could rise to close to 80 percent of GDP, which is above the Maastricht reference value. Second, the massive fiscal contraction required would put additional pressure on output, with significant risks of a downward spiral. On the upside, a faster-than-expected recovery would go some way toward mitigating both these risks.

29. In the staff's view, the likely contraction in 2010 and reliance on one-off measures in the 2009 budget will make it difficult to achieve the rapid adjustment path implied by the deficit targets in Latvia's commitment to the EC. Without additional

\footnotetext{
${ }^{6}$ In the EU, fiscal data are compiled on the basis of ESA 95 (European System of Accounts), which differ slightly from the cash deficit concept used in the program.
} 
measures the 2010 deficit is projected at 18.5 percent, including the effects of the 2009 supplementary budget and 1 percent in additional social safety net spending. This deterioration further complicates the authorities' strategy of overcoming Latvia's vulnerabilities by prompt euro adoption. As such, the authorities' already announced commitment of taking 4 percent of GDP in measures each year may be insufficient to achieve their stated deficit reduction goals.

30. In view of these concerns, the Fund-supported program allows for higher fiscal deficit targets, while still providing for a downward path of the fiscal deficit starting in 2010 (the "program scenario", Table 14, Figures 12, 14). Starting from a cash deficit of 13 percent of GDP in 2009 (as discussed above) and given the expected deficit for 2010 of $18 \frac{1}{2}$ percent without further measures, only a slight reduction in the deficit (to 12 percent of GDP) is targeted. However, as the economy recovers, more rapid declines in the deficit are projected, so that it reaches 3 percent of GDP in 2014. This path would increase public debt to 90 percent of GDP (including bank restructuring costs) in 2013, with only a marginal reduction expected in 2014 (Table 15). ${ }^{7}$ This strategy would also mean somewhat later euro adoption, which may in itself have confidence effects. On balance, the staff believes this scenario is the more feasible, and it forms the basis for the minimum fiscal adjustment that has been incorporated into the Fund-supported program.

\footnotetext{
${ }^{7}$ As a simplifying assumption, the debt analysis under the two scenarios use the same macroeconomic framework. However, it should be recognized that a more rapid adjustment scenario may be associated with somewhat weaker growth.
} 
Figure 11. Latvia: Public Debt Sustainability: Bound Tests 1/ (Rapid Adjustment Scenario, Public debt in percent of GDP)

Baseline and historical scenarios

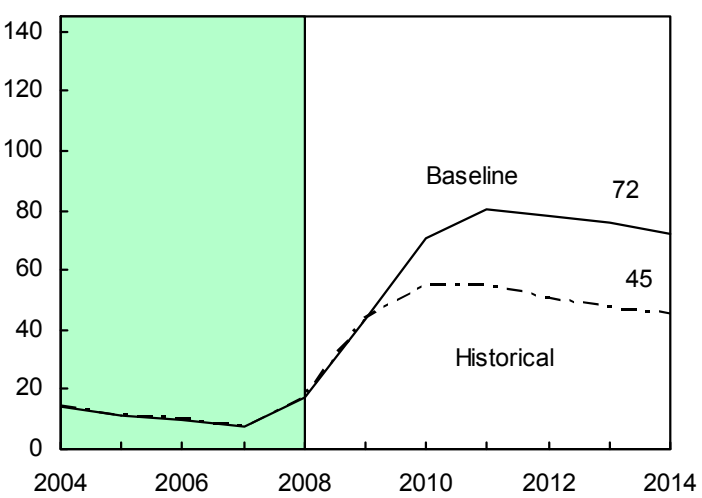

Growth shock (in percent per year)

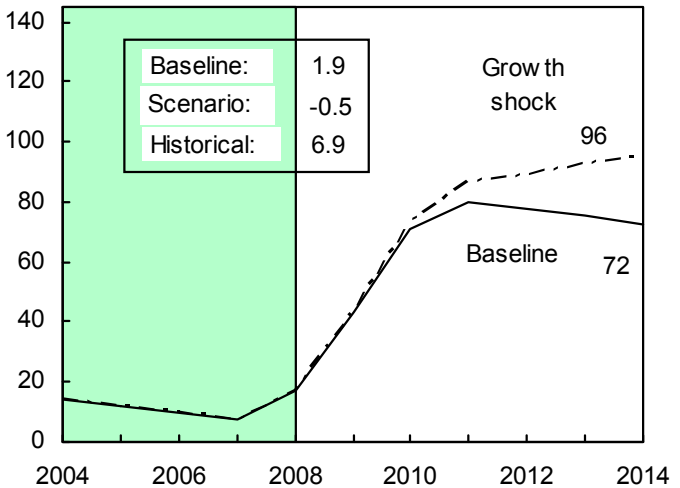

Combined shock 2/

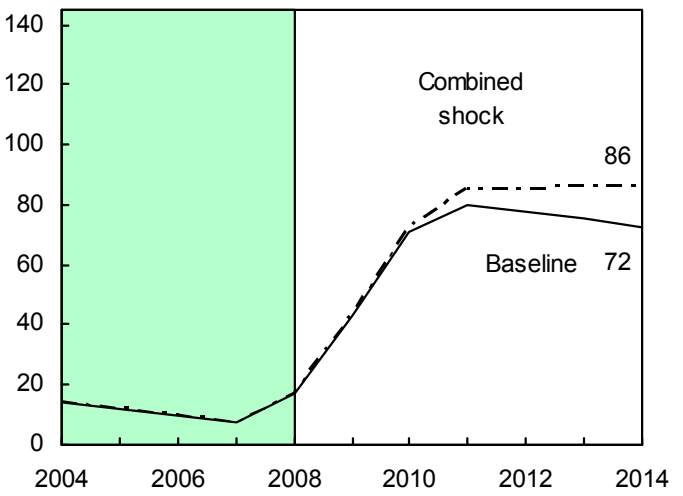

Interest rate shock (in percent)

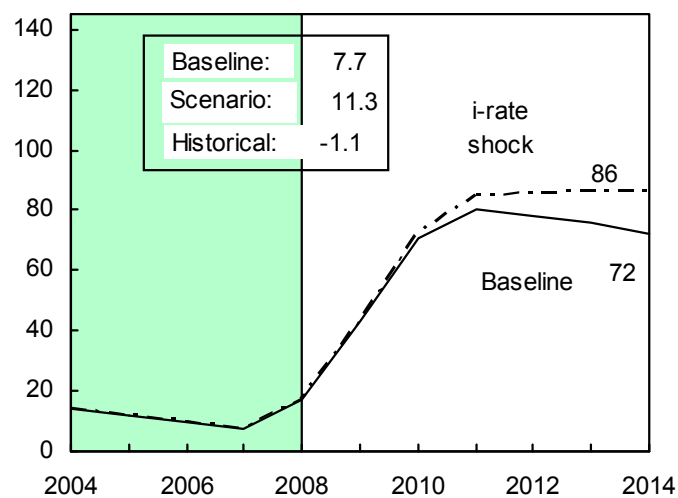

Primary balance shock (in percent of GDP) and no policy change scenario (constant primary balance)

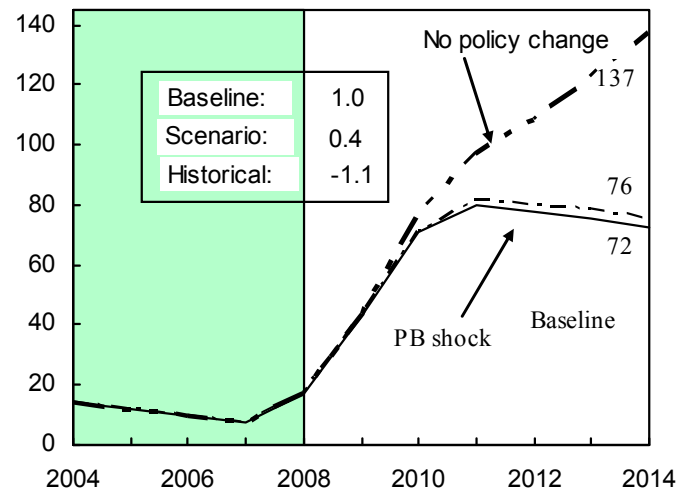

Real depreciation and contingent liabilities shocks $3 /$

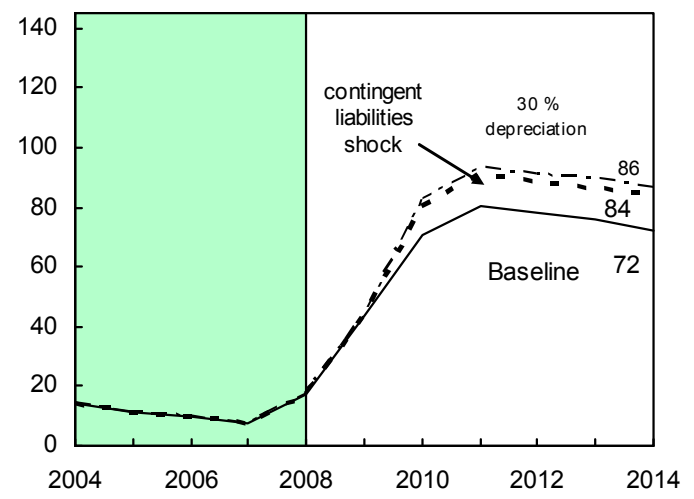

Sources: International Monetary Fund, country desk data, and staff estimates.

$1 /$ Shaded areas represent actual data. Individual shocks are permanent one-half standard deviation shocks. Figures in the boxes represent average projections for the respective variables in the baseline and scenario being presented. Ten-year historical average for the variable is also show $\mathrm{n}$.

2/ Permanent $1 / 4$ standard deviation shocks applied to real interest rate, grow th rate, and primary balance. $3 /$ One-time real depreciation of 30 percent and 10 percent of GDP shock to contingent liabilities occur in 2009, w ith real depreciation defined as nominal depreciation (measured by percentage fall in dollar value of local currency) minus domestic inflation (based on GDP deflator). 
Figure 12. Latvia: Public Debt Sustainability: Bound Tests 1/ (Program Scenario; Public debt in percent of GDP)

Baseline and historical scenarios

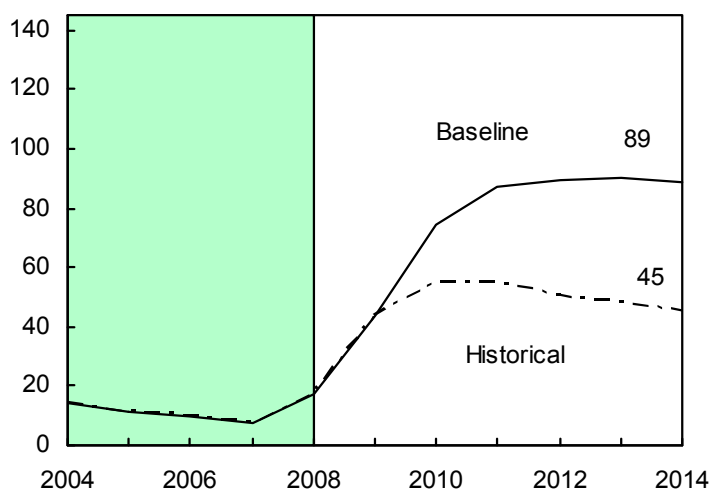

Growth shock (in percent per year)

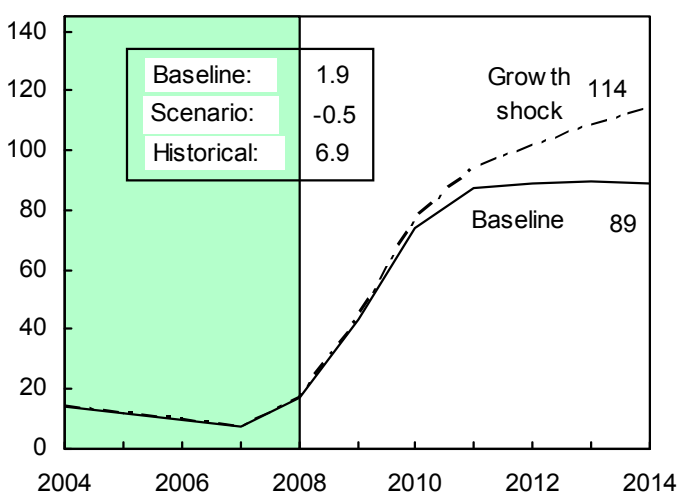

Combined shock 2/

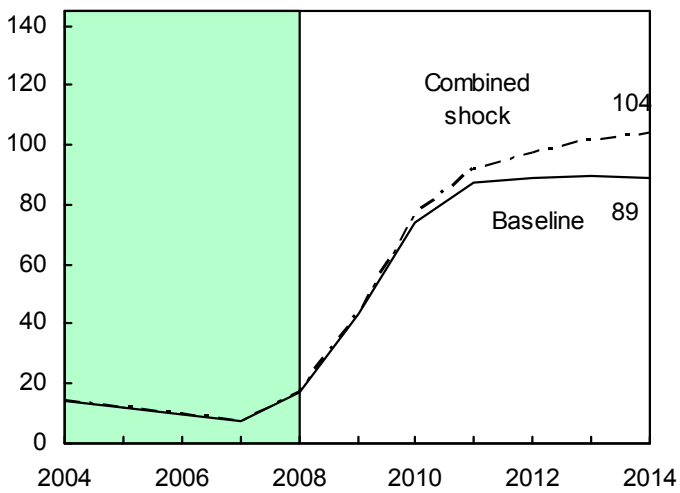

Interest rate shock (in percent)

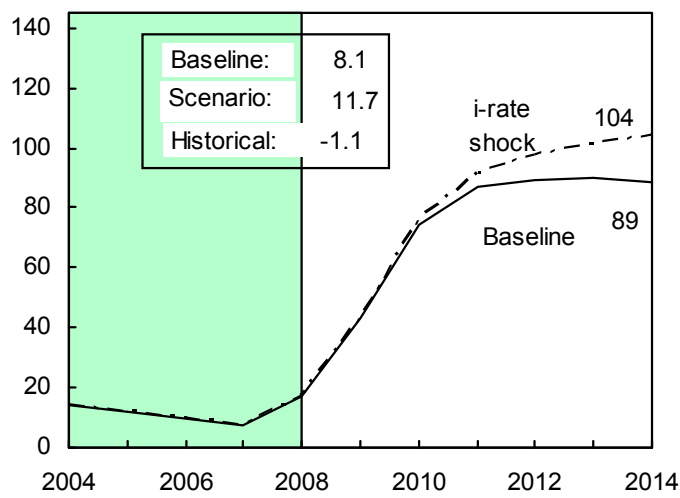

Primary balance shock (in percent of GDP) and no policy change scenario (constant primary balance)

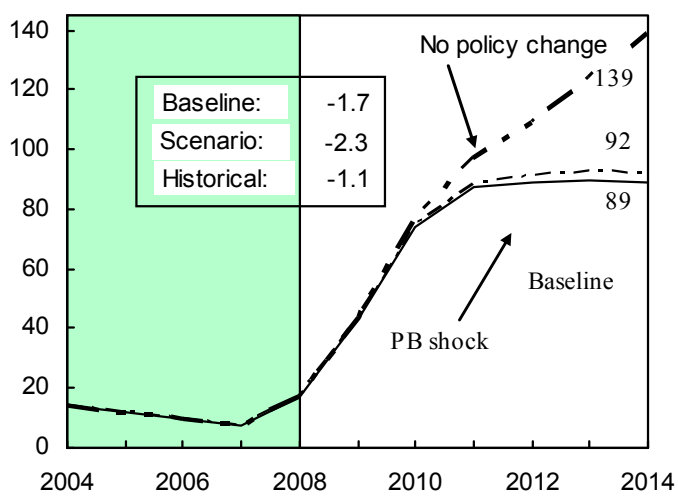

Real depreciation and contingent liabilities shocks $3 /$

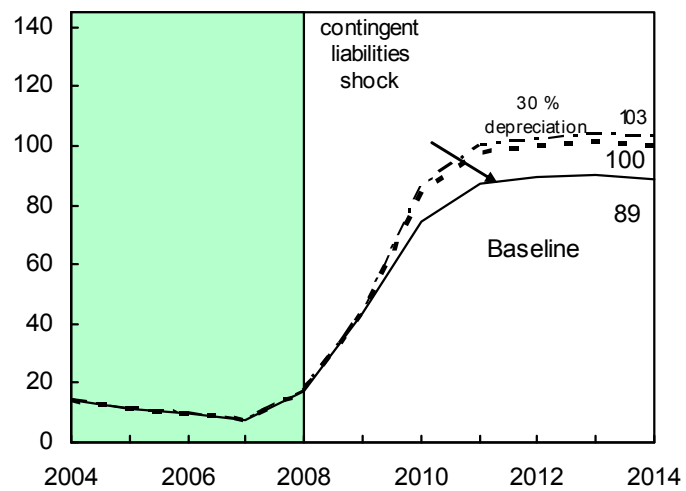

Sources: International Monetary Fund, country desk data, and staff estimates.

$1 /$ Shaded areas represent actual data. Individual shocks are permanent one-half standard deviation shocks. Figures in the boxes represent average projections for the respective variables in the baseline and scenario being presented. Ten-year historical average for the variable is also show $\mathrm{n}$.

2/ Permanent $1 / 4$ standard deviation shocks applied to real interest rate, grow th rate, and primary balance.

$3 /$ One-time real depreciation of 30 percent and 10 percent of GDP shock to contingent liabilities occur in 2009, with real depreciation defined as nominal depreciation (measured by percentage fall in dollar value of local currency) minus domestic inflation (based on GDP deflator). 
Figure 13. Latvia: Program and Rapid Adjustment scenarios, July 2009
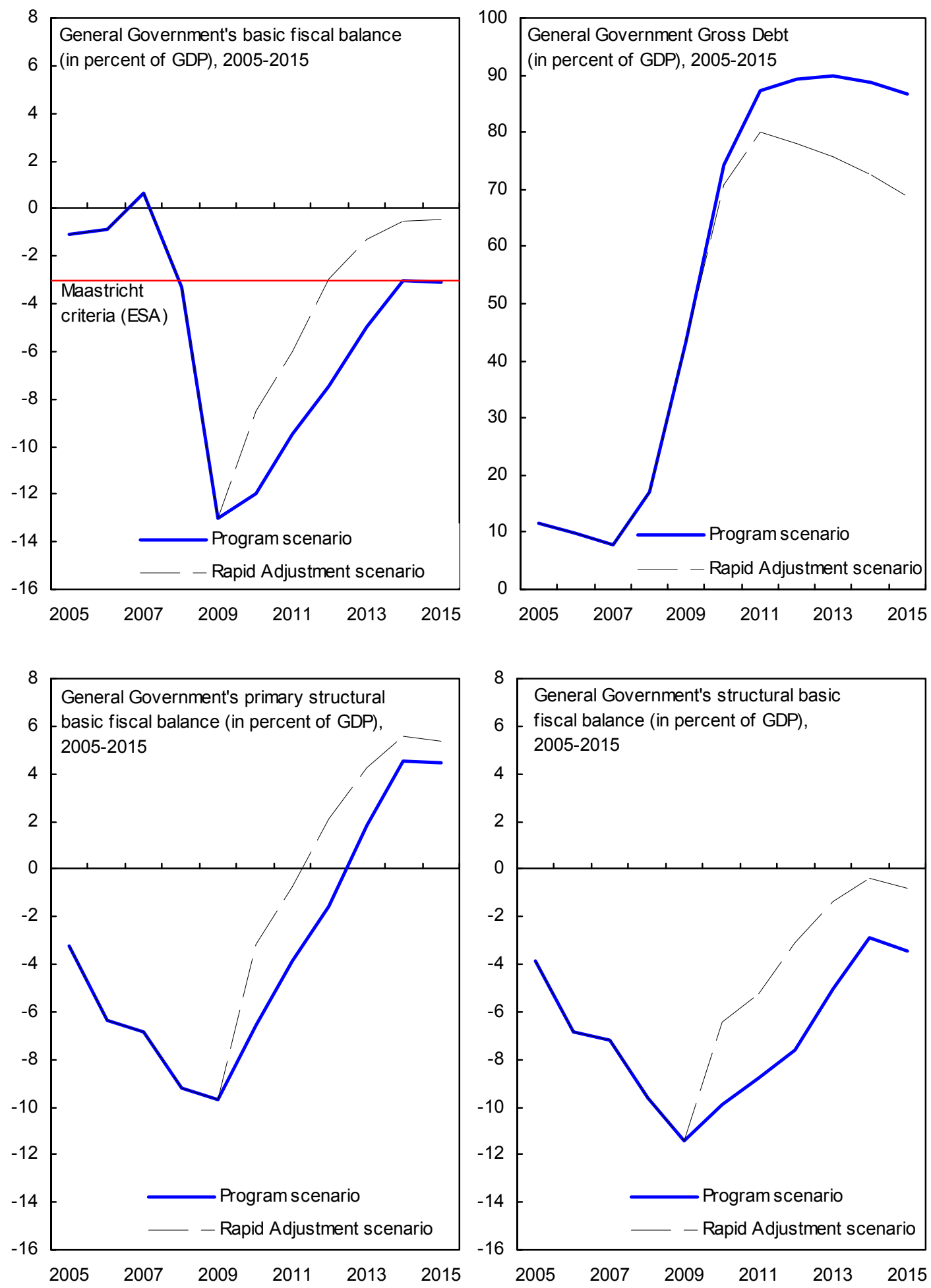

Source: Latvian authorties, Fund Staff Estimates. 
31. However, both scenarios face substantial risks. More rapid and sustained deflation than envisaged under the program would lead to substantially higher government debt ratios. Likewise, slower deficit reduction (for example, due to reform fatigue) would also result in government debt ratios approaching 100 percent of GDP.
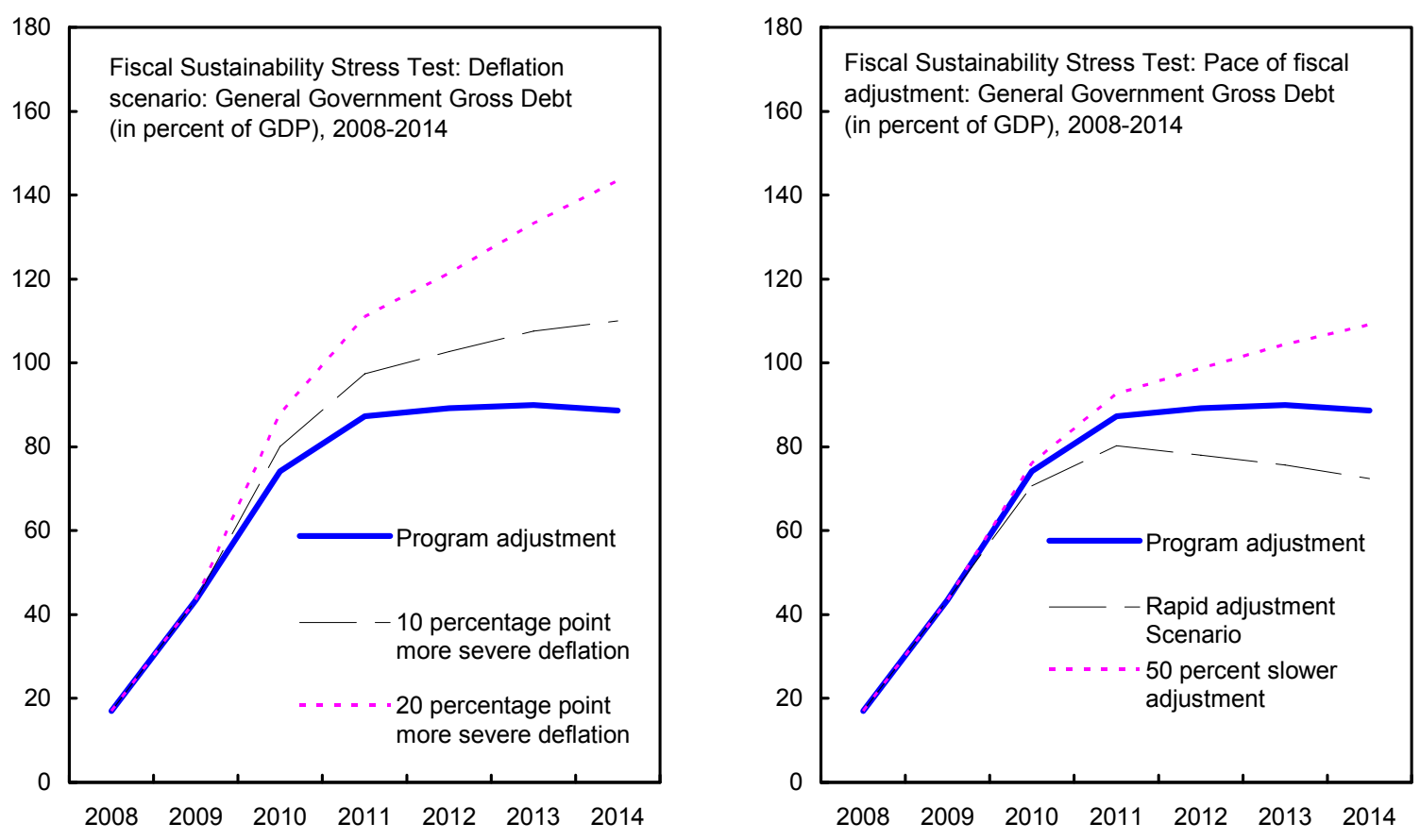

The 2010 Budget

\section{The authorities are committed to taking whatever measures are needed to} ensure that the deficit declines in 2010 (LOI $\mid 20-22)$. This includes 4 percent of GDP from tax measures, harmonizing government salaries, and targeted expenditure cuts. The authorities have also broadly identified a further $2 \frac{1}{2}$ percent of GDP in measures and will implement measures of this scale as necessary to meet their fiscal objectives; such measures include increasing VAT and introducing a progressive personal income tax. These should be sufficient to reduce the cash deficit to around 12 percent of GDP, in line with the revised program. However, given that the 2010 budget preparations had not started, only around half of these measures have been identified.

\section{Staff see these measures as a first step towards a sustainable fiscal adjustment.}

Subjecting capital income to PIT and taxing residential real estate will broaden the tax base. Disparities in allowances across all sources of income, including pensions and wages, will be reduced. Introducing a progressive PIT would also help ensure a fairer burden of adjustment, although the authorities see this measure as inconsistent with their low-tax economic model 
and are concerned that high earners would evade it by recording incomes offshore. On the expenditure side, the commitment to a broad public-sector employment reform generating a $1 / 2$ percent of GDP reduction in the public-sector wage bill should address a major source of fiscal slippage during the boom. However, the authorities need to develop further their planned $3 \frac{1}{2}$ percent of GDP in expenditure cuts. The plans will need to be fully specified and agreed as part of discussions of the 2010 budget this fall and will be a key element of the next review. To improve prospects for implementation, the government has committed to including coalition members and social partners throughout budget preparation this fall. The government is also committed to further deficit reduction from 2011 onwards, mainly through expenditure restraint ( $\mathrm{LOI} \uparrow 24)$.

\section{Financial Sector Policies}

34. The authorities and the banks are responding quickly to strains caused by the downturn, lower real estate prices and global deleveraging. To assess the true deterioration of banks' loan portfolios, the FCMC has begun examining how banks are restructuring loans to ensure they are not "evergreening", and monitoring special purpose entities the banks have set up to manage non-performing assets and foreclosed collateral (LOI 930 ). Capital buffers should be maintained substantially above the regulatory minimum in anticipation of further losses, and for depositors to remain reassured.

\section{The Nordic-owned banks have responded quickly to the deterioration in loan} quality. The program sought assurances from parent banks that they would ensure their subsidiaries have adequate capital and liquidity. Two of them, accounting for 30 percent of Latvian bank assets and resident deposits, have already received capital injections of $€ 390$ million, which should support confidence. Building on their existing commitment letters, foreign banks' exposure to Latvia and support for their subsidiaries will be discussed and endorsed in a Bank Coordination Initiative meeting in Stockholm scheduled for early September.

36. Domestically-owned banks pose particular risks, especially those in state ownership:

- Staff urged the authorities to tighten supervision of domestic banks' liquidity, which has been strained by non-resident deposit outflows and repayment of syndicated loans. The FCMC now has stronger powers to intervene in these banks in the event of systemic threats (Box 5).

- The authorities are developing a strategy to refocus the Mortgage and Land Bank (LOI q33). Its commercial banking operations will be scaled back, to build up development banking (including SME finance) financed by EU funds and IFI loans. Staff urged the authorities to assess the bank's capital needs. 
- The authorities have made progress in resolving the other majority state-owned bank, Parex. It was recapitalized in May by converting L190 million of deposits into equity and subordinated debt, and its CAR has reached 11 percent. On top of its recent loans, the EBRD intends to acquire a 25 percent stake (which should also help rebuild confidence) and deposit outflows have stabilized. However, the bank continues to depend on government liquidity support and partial deposit withdrawal restrictions remain in place. In July the European Commission (DGCOMP) began an investigation into the state aid provided to Parex (prolongation of State guarantees, potential new State guarantees to ensure further funding needs of the bank, liquidity measures and capital injections) to determine the viability of Parex's restructuring plan, in line with the EU's competition rules. ${ }^{8}$

\section{The authorities have continued to make good-faith efforts to facilitate the} settlement of limited arrears arising from the partial deposit freeze at Parex Bank. The bank's liquidity position improved after its largest depositors agreed to extend the term of over L300 million of deposits affected by the exchange measure. It has required no further liquidity support this year, but will be unable for some time either to repay the L840 million of support it received last year, or to resume normal operations. The IMF Executive Board therefore recently approved the retention of this exchange restriction until end-November 2009 or Latvia's next Article IV consultation, if completed earlier (EBD/09/51). The authorities are committed to removing the restriction once conditions stabilize.

38. The authorities are speeding up work on developing a strategy for recapitalizing or resolving troubled banks (LOI \28). A comprehensive strategy is required to avoid ad hoc decisions in the event banks come under pressure. To ensure it is based on solid analytical foundations, Staff proposed that the recent top-down stress tests be complemented by bottom-up tests run by the banks themselves on the basis of a uniform macroeconomic scenario. The World Bank provided technical assistance for inputs into this strategy and drafts of the strategy will be discussed with the Fund, EC and World Bank staff before being finalized. The Latvian authorities are also likely to participate in an IMF-coordinated regional stress-testing exercise. The FCMC recognizes that it needs to cooperate closely with home supervisors of the major foreign banks if their strategy is to work.

\footnotetext{
${ }^{8}$ The EC indicated that: "opening of an investigation is common for state interventions in the banking sector, ensures legal certainty for the concerned market players and gives interested parties the possibility to submit comments on the proposed measures. It does not prejudge the outcome of the procedure."
} 


\section{Monetary Policy}

39. Discussions focused on recent foreign exchange and money-market volatility, and policies to counteract it:

- Staff expressed concerns at the lowering of reserve requirements in late 2008, which had created excess lats liquidity, and cuts in official interest rates in January, March and May. Though these had limited effects on market rates they sent the contradictory signal that monetary policy was being loosened, which was not consistent with the need to defend the peg. The Treasury's practice of selling program funds on the open market meant that the Treasury not the central bank seemed to be in charge of intervention policy.

- $\quad$ From April onwards, the authorities responded by issuing more domestic treasury bills. This helped absorb excess liquidity, and dramatically slowed the pace of foreign exchange intervention. However, when speculative pressures emerged again in June, the Treasury's insistence on continuing treasury bill sales despite shortages of lats liquidity contributed to sharp interest rate increases; indeed the failure of one of these auctions added to speculative pressures. The authorities recognized the need for coordination between the Treasury and BoL to reduce volatility and improve confidence.

40. Staff encouraged the BoL to play a stronger role in managing lats volatility, while respecting the constraints implied by its quasi-currency board (LOI 925 ). From now on the Treasury will exchange program funds with the BoL off market, so that it will no longer have a direct influence on the foreign exchange market (LOI 926 ). This will imply that liquidity is created whenever program funds are spent (since the Treasury will draw down its lats deposit at the BoL). If the liquidity creation is excessive, then the Bank of Latvia should decide whether to use deposit auctions or other new instruments to mop this up, or to sterilize through foreign exchange sales. The authorities committed to consult with IMF staff before any changes in official interest rates and minimum reserve requirements (LOI $\mid 25$ ). The Bank of Latvia expressed willingness to consider such approaches to dampening volatility, but stressed that its commitment to the currency peg remained inviolable. It therefore had no intention of implementing discretionary monetary policy.

41. The authorities plan to increase the share of the deficit financed from privatesector sources (LOI $\mid 18$ ). Building on the boost to market confidence from the international financing package, the Treasury intends to increase domestic treasury bill issuance. However, they are also considering issuing euro-denominated or euro-indexed domestic debt, which would offer banks an asset to offset short euro positions caused by provisioning for bad loans. It is intended to encourage them to retain liquidity in Latvia, and could reduce the drain on reserves. 


\section{E. Private Debt Restructuring}

42. Rising debt distress has prompted demands for a government response. Banks have called for government loan guarantees, while some politicians have advocated a moratorium on mortgage foreclosures.

43. In June, the authorities adopted a comprehensive debt restructuring strategy that relies primarily on a market-based approach (LOI $\mid 35-36)$ :

- In line with this approach, insolvency legislation has been strengthened and incentives improved for out-of-court restructuring of corporate debt, drawing on IMF Legal Department and World Bank missions and technical assistance (Box 6). The legal framework for restructuring household debt has also been improved.

- The strategy also includes a scheme to assist household borrowers, which would offer government guarantees for restructured loans on condition that debt service is reduced and part of the loan is forgiven once the borrower has resumed repayments. However, this would be activated only if there was a significant improvement in the headline fiscal balance (before bank restructuring costs). The authorities have put aside the idea of creating an asset management company, though they might reconsider if the situation worsened.

44. The authorities will continue to strengthen market-based aspects of the debt restructuring strategy. They will establish guidelines for corporate workouts mid-August, and will streamline liquidation and foreclosure procedures through amendments to insolvency and other legislation to be submitted to parliament by October (structural benchmark). In line with staff advice, the authorities intend to raise awareness of the new insolvency framework, and to organize training to encourage lawyers and other practitioners to use the new tools. Technical assistance, including advisory services for distressed debtors, is under consideration.

\section{Program Modalities and Safeguards Assessment}

\section{Latvia faces a continuing balance of payments need as nonresidents further} reduce their exposure to the economy, and as resident demand for foreign currency continues (Figure 13). In this context, IMF financing is crucial to strengthen reserves until the economy can be stabilized and pressures on the balance of payments subside.

\section{Program funds will be used to finance Latvia's balance of payments deficit and} strengthen its gross reserves. All program funds will be transferred to special sub-accounts of the Treasury euro-account at the BoL. Three-quarters of this will be placed in an account for budget support, addressing the incipient balance of payment drains implied by the much higher budget deficit. The remaining financing will ensure that there are sufficient reserves to cover likely and contingent drains arising from bank restructuring. The Ministry of Finance 
will consult with staff should the sum of the balances in accounts intended for budget support fall by more than $€ 250$ million in any 30 -day period.

47. Latvia's SDR allocation is expected to provide an additional financing buffer for the remainder of this year. Latvia will receive an additional SDR 26.8 million with approval of the Fourth Amendment of the Articles of Agreement, and about SDR 93.0 million as a result of the general SDR allocation - in total about 90 percent of quota. The initial allocation does not affect the level of NIR under the program definition and no change in program NIR targets is proposed. The accounting treatment for these resources is still to be determined by the Latvian authorities; staff will review the effects of the allocation on the program framework at the next review.

\section{The attached Letter of Intent and Technical Memorandum of} Understanding (TMU) summarizes the authorities' progress in implementing their economic program and sets out conditionality through December 2009 (LOI $92-4$, and LOI Tables 1-3).

- Modifications to existing conditionality. The BoL has agreed to tighter targets for net international reserves and net domestic assets, to lock in buffers from end-December 2008. The TMU adds an adjustor for NDA to give the BoL room to provide emergency liquidity assistance in line with its recently adopted operational guidelines (structural benchmark), if needed, without missing the target. An adjustor to the budget balance target allows increased spending to strengthen social safety nets. The fiscal deficit target, which was previously based on an adjusted version of the actual budget balance, is now based on an adjusted primary balance to better capture the government's fiscal tightening efforts, against a backdrop of increased general government debt and volatile domestic interest rates.

- The proposed program includes a new performance criterion and seven new structural benchmarks (Box 7). A quantitative performance criterion-a ceiling on public guarantees - has been added to help safeguard fiscal sustainability. Seven new structural benchmarks are proposed, all of which are critical for achieving program objectives. They relate to bank restructuring, stress tests, bank supervision, social safety net, closure of an off-budget fund, and wage formation policies.

- $\quad$ Rephasing of purchases. In light of the delays, the proposed program resets the Second Review test date to end-September, with quarterly reviews to follow, as in the existing program. The total number of reviews will be reduced from nine to seven, and the remaining financing smoothed out over the remaining six reviews (Table 16)

- The level of access remains unchanged (Tables 17-18). 
Figure 14. Latvia: External Debt Sustainability: Bound Tests 1/ (External debt in percent of GDP)
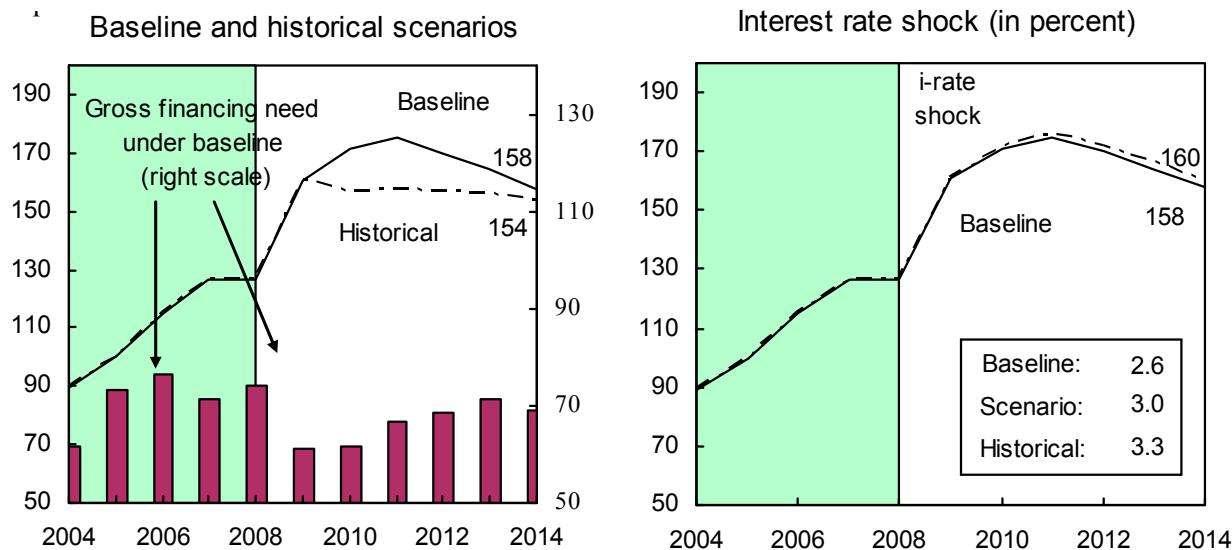

Growth shock (in percent per year)

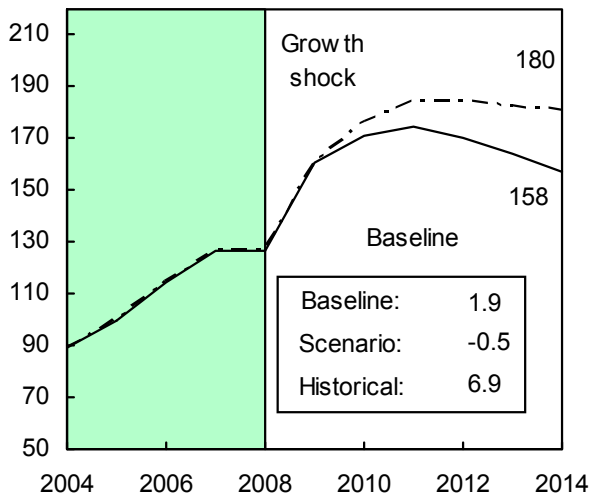

Non-interest current account shock (in percent of GDP)

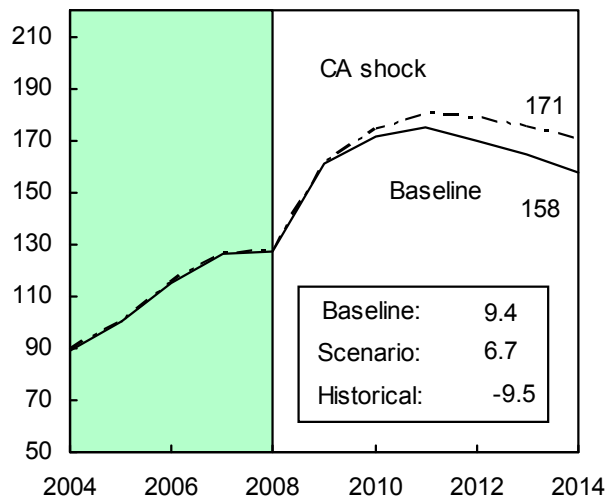

Combined shock 2/
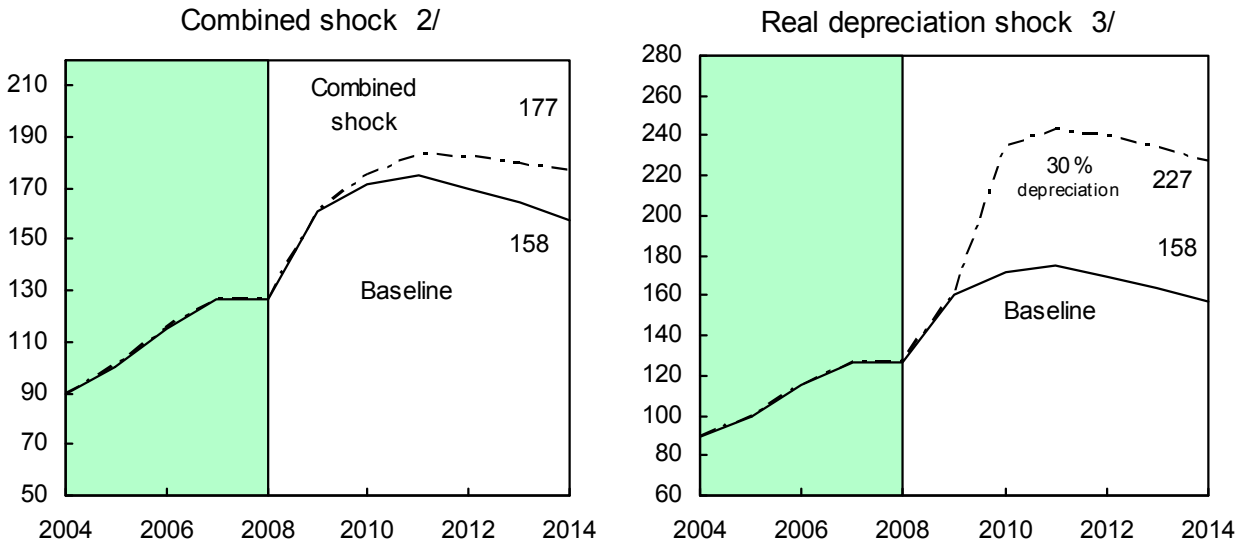

Sources: International Monetary Fund, Country desk data, and staff estimates.

$1 /$ Shaded areas represent actual data. Individual shocks are permanent one-half standard deviation shocks. Figures in the boxes represent average projections for the respective variables in the baseline and scenario being presented. Ten-year historical average for the variable is also shown.

2/ Permanent 1/4 standard deviation shocks applied to real interest rate, growth rate, and current account balance.

3/ One-time real depreciation of 30 percent occurs in 2009. 
49. The safeguards assessment concluded that the BoL operates robust internal audit and control systems. The assessment recommended clarifying the BoL and Treasury's respective roles in holding, managing, and reporting to the Fund international reserves. It also proposed amendments to the mandate of the BoL's audit committee. The authorities have begun implementing these recommendations.

\section{Risks to the Program and Capacity to Repay}

50. Risks to the program are many, inter-related, and unusually high:

- $\quad$ The much higher government deficits will make it harder to meet the Maastricht criteria and may delay the program's exit strategy of euro adoption. In the worst case, if the contraction proves deeper or the authorities prove unable to deliver on the minimum fiscal adjustment in the program scenario (Latvia's track record so far has been weak, though the change in government could change this), the resulting high deficits would raise risks to debt sustainability and capacity to repay the Fund.

- $\quad$ Fiscal financing constraints could emerge. Even if the authorities impose cash controls or run arrears in the short run, their medium-term financing needs will increase without structural reforms to public expenditure. Projected private sector financing needs by the end of the program period are high — domestic financing is assumed to be 13 percent of GDP in 2011 — and will likely be difficult to achieve, especially in the presence of delays to euro adoption (which would otherwise make it easier for the Latvian government to issue debt, and hence to repay the Fund) and increasing public debt. This suggests substantial risks of more prolonged need for extraordinary official financing support.

- The authorities' strategy of correcting real exchange rate misalignment without a nominal depreciation remains challenging. Although factor prices seem to have started adjusting, trading partner currencies have depreciated sharply, and the real exchange rate remains overvalued, suggesting that a current account problem may reemerge once the economy returns to growth. At the same time, the strategy implies depressed demand for some time, which will dampen growth and in the worst case, could be accompanied by deepening financial sector problems if non-performing loans continue to increase.

- Deflation may be even deeper than currently projected, which could also jeopardize euro adoption. Other things equal, more rapid deflation will result in a greater competitiveness improvement, and better prospects for sustainable growth. However, in the absence of precedents it is unclear how the European institutions will judge continued deflation in the context of requirements for price stability, creating further uncertainty for euro adoption. Deflation will also exacerbate fiscal difficulties, as the government may find it difficult to bring about further nominal reductions in 
wages, pensions, and budget allocations, and it makes it harder to achieve debt sustainability.

- $\quad$ Public support for the current strategy could falter. Rising unemployment could reduce the government's popularity and cause undue social hardship, unless the authorities make use of the extra fiscal space in the program and act quickly to strengthen the social safety net. This could undermine the authorities' implementation of their chosen economic strategy. Difficulties of implementing further fiscal measures ahead of the 2010 parliamentary election create an additional complication, as undertaking successive rounds of fiscal adjustments could create "fatigue" and put implementation at risk. Communication by the government regarding the growing fiscal deficit (and putting into context the sacrifices needed to address it) has been limited.

- $\quad$ Private sector confidence in the strategy could be tested. The speculative attack on the lats in late May demonstrates that many parties - Latvian corporations, banks based in Latvia, politicians, market analysts, and even one of the Prime Minister's former advisors - may have questions regarding the program strategy.

51. The revised program framework, reinforced by continued international support, particularly from the EU, seeks to mitigate these risks. In addition, the support of Latvia's international partners, particularly the EU, represents a key safeguard to the IMF program. The EU's commitment of $€ 3.1$ billion under the international support package has provided important space for implementation of the programmed reforms. In a July 27 press statement announcing their disbursement of $€ 1.2$ billion, the EU affirmed that it will continue to work closely with the Latvian authorities and the IMF to ensure Latvia implements successfully its economic reform program and its timely repayment of, all loans associated with the international program to support Latvia.

52. Latvia's capacity to repay the Fund is expected to be adequate. By the end of the arrangement, Fund exposure is projected to be about 10 percent of GDP, about 30 percent of gross reserves (Table 18). Public debt increases substantially over the program (and there are also contingent banking sector liabilities), and fiscal financing requirements in the post-program period are high. External debt to GDP also jumps to around 175 percent (as nominal GDP falls sharply), before falling steadily from 2011 onwards (Tables 7-8). While these risks are significant, continued current account surpluses, Latvia's strong commitment to the program, expected improvements in global financing conditions, and EU support provide key safeguards.

\section{Staff APPRAisal}

53. The deep domestic contraction and global market strains pose major challenges to Latvia. The program strategy of adjustment under the existing fixed exchange rate has become even harder as trading partners' currencies have depreciated. Factor price adjustment 
will likely be more prolonged and painful than was assumed when the program was initiated. As global demand is still too weak to pull Latvia out of its downturn, an extended period of contraction, rising unemployment, falling tax revenues and fiscal adjustment lies ahead. Even so, securing both public and external debt sustainability remains challenging under program assumptions.

\section{Even taking into account the difficult background, implementation under the} program has been mixed so far. Reserve and monetary targets were comfortably met, as were financial sector and debt restructuring structural benchmarks. However, the quantitative fiscal performance criteria were missed and domestic government arrears have emerged. On the basis of the subsequent measures taken by the authorities as well as new commitments, staff support the authorities' request for waivers on the nonobservance of the March fiscal quantitative performance criteria, the performance criterion on non-accumulation of general government arrears, and the structural performance criterion on submission of a supplementary budget.

55. Latvia faces daunting obstacles on its way to euro adoption, the exit strategy envisaged under the program. The general government deficit is likely to exceed 12 percent of GDP in 2009, and would increase further in 2010 without significant further measures. In addressing these objectives, there is a need to balance a number of competing objectives: defining a sustainable and structurally sound strategy for fiscal reform, consistent with Latvia's strategy to adopt the euro at the earliest possible date, against the need for flexibility in the fiscal deficit target to minimize further pressure on economic activity and to protect the most vulnerable at a time of painful dislocation. In this context, attaining the Maastricht government deficit and debt criteria may prove more protracted than originally envisaged, with potential confidence effects from possible delay in euro adoption.

\section{The 2009 supplementary budget, while including some tough decisions, has} serious drawbacks. The backing of social partners is unprecedented and welcome. There remain important questions, however, whether these measures will be fiscally and socially sustainable.

57. The revenue measures have downsides. The reduction in the personal income tax allowances disproportionately affects lower-income earners, and the remaining measures are largely one-off. Increased dividends from state enterprises will deplete their capital when profitability is under pressure. A planned doubling of transfers from the BoL to the budget has been dogged by criticism from the ECB, as it could dent monetary and financial credibility.

58. The expenditure measures are unlikely to be fully sustainable. The across-theboard cuts will be difficult to implement, especially in healthcare and education. The supplementary budget lacks sufficient funding for local governments, which are responsible for delivering basic social assistance. The authorities have indicated their willingness to 
provide additional social assistance funding for local governments that run out of money, on a case-by-case basis; it is critical that they do so, even at the cost of a wider deficit this year.

59. In view of the deteriorating medium-term fiscal position and exceptionally weak macroeconomic situation, staff would have recommended a more targeted supplementary budget based on structural reforms. Staff regrets the recourse to one-off measures and across-the-board cuts, instead of building the package of structural reforms envisaged in the original program strategy. Fund staff strongly encourages the authorities to implement the recommendations of the recent World Bank mission to strengthen social safety nets. The performance criterion for the 2009 fiscal deficit has been increased to allow this, and for the reversal of the most socially painful cuts in the supplementary budget.

60. Implementation of fiscal policy will need to be significantly strengthened for the strategy to succeed. Fiscal consolidation has to contend with headwinds from the output deterioration - and deflation - that are eroding the revenue base. In the staff's view, for the strategy to succeed, measures amounting to $6 \frac{1}{2}$ percent of GDP in 2010 are needed to reduce the deficit, followed by approximately 4 percent of GDP in measures each subsequent year until the deficit can be brought below 3 percent of GDP, consistent with the authorities' strategy of achieving the Maastricht deficit criterion as soon as possible. Of course, a stronger and more rapid economic recovery than expected would greatly ease this task, and assuage some of the staff's concerns. But the collapse of the real estate bubble and related nontradable sector activity suggests that Latvia has experienced a permanent output loss, and will need to match this with permanent cuts in government spending or tax increases.

61. The revised LOI, with the support of all coalition partners, brings together elements that could resolve Latvia's fiscal and external vulnerabilities, but only if implemented vigorously and consistently. The plans will need to be fully specified and agreed as part of discussion of the 2010 budget this fall and will be a key element of the next review.

62. Restoring confidence in the financial sector requires a strategy to ensure banks remain liquid and adequately capitalized. Preemptive capital increases by two large foreign banks are welcome and will give them scope to absorb the loan losses likely in the coming months. The authorities should seek to minimize the contingent liabilities from domestic banks, particularly those in state ownership, and restrict issuance of new guarantees, which would only add to Latvia's fiscal problem. The authorities' continued good-faith efforts to facilitate the settlement of limited arrears arising from the partial deposit freeze at Parex Bank are welcome.

63. Refinements to monetary policy implementation should help reduce interest rate volatility. The agreement to exchange program money off-market, which will reduce the Treasury's direct influence on the exchange rate, is welcome. The BoL, in cooperation with international experts, will continue to enhance its approach to liquidity management, adding 
new instruments where necessary and if consistent with the constraints posed by the quasi currency board. Although interest rate volatility is inevitable under a currency board, these initiatives should prevent volatility from being excessive, which would be destabilizing.

64. The staff assesses that the program is fully financed in the next 12 months, but significant risks remain, particularly over the medium term. Increased use of program funds for budget support has limited the amount of resources available for bank restructuring. A recent agreement will therefore ring-fence a share of program funds for this purpose.

Increased budget expenditure has spurred capital outflows, outweighing the correction in the current account. From 2011 onwards, the authorities will need to start repaying program partners, and fiscal financing will become more difficult, notwithstanding expected improvements in international market conditions. Program partners should consider making grant financing available for urgently needed social safety net reforms, and more generally to support debt sustainability.

65. Macroeconomic, political and practical implementation risks have increased. The outlook has become more uncertain, with downside risks. Public and political support for the program may come under increased pressure as the downturn drags on, and the 2010 parliamentary election approaches. Moreover, institutional weaknesses will handicap the authorities' efforts to design structural reforms or ensure that line ministries respect expenditure targets and to ensure tax compliance. The Fund and program partners are providing technical assistance to help address these weaknesses, but this TA will take time to bear fruit.

66. Staff recommends completion of the first review and the financing assurances review under the SBA, the granting of the needed waivers for nonobservance of performance criteria, and rephasing of amounts committed under the Arrangement on this basis. The commitments by Latvia under the revised LOI to substantial corrective measures, including additional fiscal measures, are critical to putting the program back onto a sustainable path, recognizing the substantial risks identified above. The EC, Nordic countries and other program partners are providing strong financial support to the program and, together with the authorities, remain committed to Latvia's macroeconomic strategy. In this context the EU's commitment to work with the Latvian authorities and the Fund to ensure that Latvia implements its program successfully and its timely repayment of all program loans, including obligations to the Fund, provides important safeguards to the Fund. 


\section{Box 1: Reassessing the Output Gap}

The sharp decline in GDP underlines the need for reassessing the output gap and the structural fiscal balance. Given the severity of the decline, part of the output loss is likely to be permanent, as medium-term projections do not indicate a reversion back to the initial trend. In addition, the sharp contraction of sectors such as real estate and financial services points toward the unwinding of a bubble that emerged during the 2004-07 boom. With permanent effects on potential output, the current output gap is small relative to the size of the contraction. This means that much of the fiscal deficit is likely to be structural, not just cyclical.

The exact size of the output gap is uncertain, due to difficulties in applying standard estimation techniques. First, the time series is short, leading to few degrees of freedom. Second, only the early part of the sample is likely associated with normal, sustainable growth, given the extremely rapid growth in the years leading up to the current crisis. Further, a possible structural break in the current crisis undermines the reliability of common approaches such as the HP filter or the production function. These caveats imply that estimates of the output gap are subject to a considerable margin of error, though the alternative methods yield broadly similar results.

The 2009 output gap is much smaller than the projected decline in GDP. This reflects two factors. First, the output gap in 2008 was large and positive following double-digit growth in pre-crisis years, only part of which was associated with sustainable growth in potential output. Second, potential growth is likely decelerating, lowering the level of potential output below the original trend. As such, GDP in 2009 is likely to be $6-8 \frac{1}{2}$ percent below potential with production function approaches generally providing more negative output gaps in 2009 than HP filters. When compared to the projected 18 percent decline in output in 2009, the estimated output gap in 2009 is small.

Latvia's output gap exhibits a similar pattern to that of Asian countries before and after the Asian crisis. Several of them had substantial positive output gaps, followed by a fall below potential during the crisis. The subsequent economic recovery to close the output gap took several years in some countries (Indonesia and Thailand). There was no clear reversion back to the initial trend level of GDP, as the level, and in some cases the growth rates, of potential output fell.

In Latvia, the large output gap in 2009 suggests a large structural fiscal deficit. We assume the structural fiscal balance is a function of the actual fiscal balance and the output gap. Applying a fiscal response coefficient of 0.4 on the output gap ${ }^{1}$ and an estimated baseline fiscal deficit of 16 percent of GDP, an output gap of $-81 / 2$ percent would imply a structural fiscal deficit of around $12 \frac{1}{2}$ percent of GDP. This suggests that much of Latvia's fiscal deficit is structural, and so will not disappear automatically with the end of the cycle. 


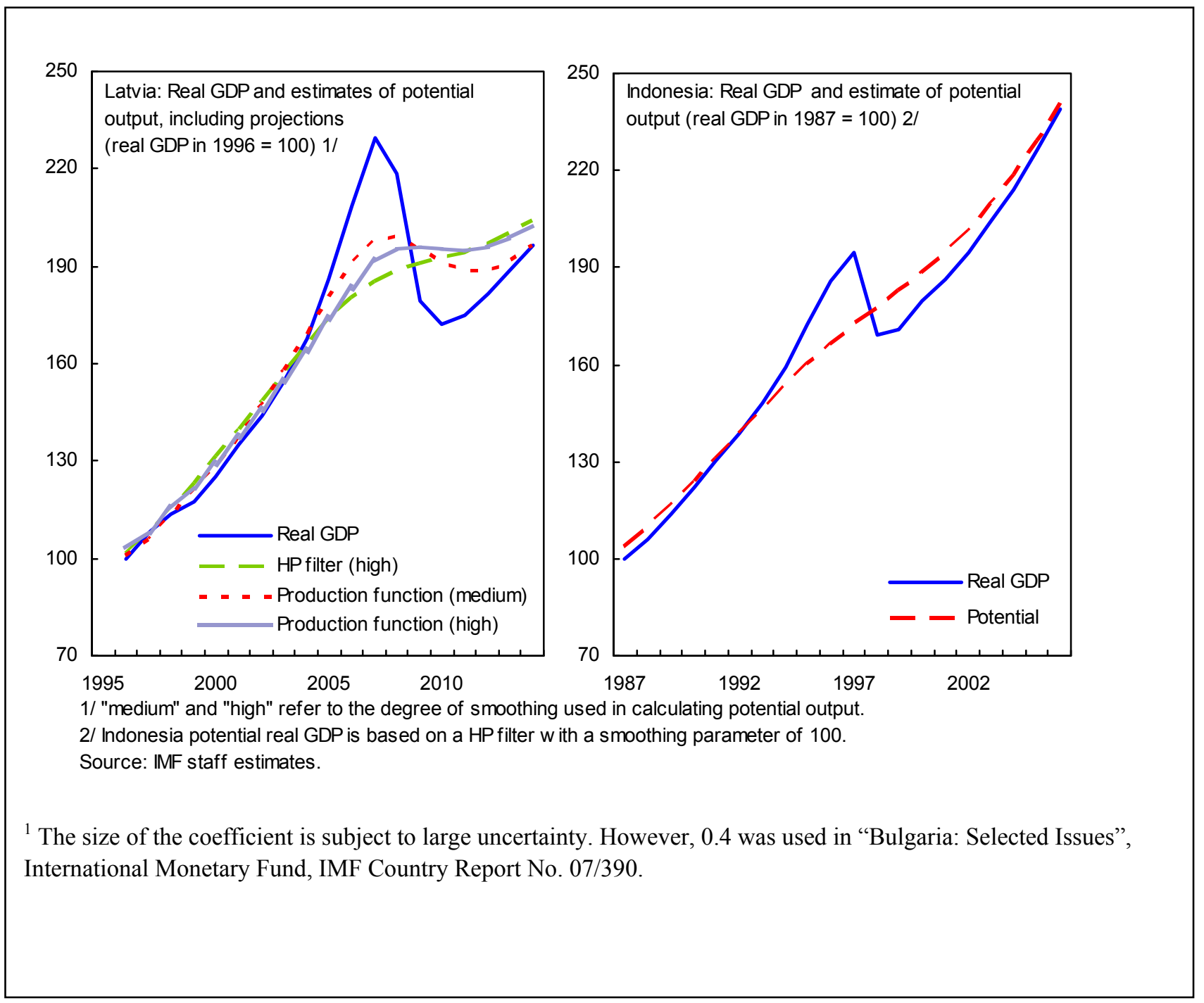




\section{Box 2: Currency Board Adjustment: The Experience of Hong Kong SAR}

Prices are likely to fall in Latvia. First, wages and prices increased substantially during the boom, and the real exchange rate is estimated by staff to be overvalued. Second, banks are losing money, and there are few prospects for new lending, so the financial sector is unlikely to boost growth. Third, fiscal contraction to achieve euro adoption will constrain demand and prices.

Moreover, successful currency board adjustment requires low inflation or deflation, as Hong Kong SAR's experience from the mid-1990s illustrates. Hong Kong SAR is a flexible economy with a currency board arrangement. In the 1990s it had a large financial sector, and was undergoing rapid regional integration, to some extent like Latvia today.

In common with Latvia, Hong Kong SAR experienced: (i) a real estate boom (led by private-sector borrowing) and bust; (ii) a regional crisis (the Asian crisis, followed by the bursting of the dotcom bubble and then SARS); (iii) sharp current account turnaround; (iv) adjustment through deflation.

That said, there are important differences: (i) the current account deficits in HKSAR never exceeded 20 percent of GDP (as they have done in Latvia); (ii) fiscal surpluses in the boom created fiscal space (Latvia recorded only one small surplus during its boom); (iii) HKSAR was able to expand fiscal policy post-bubble, while Latvia has to contract to achieve euro-entry; (iv) HKSAR was integrating with mainland China (lower price level), while Latvia is integrating with mainland Europe (higher price level); (v) HKSAR has a much higher share of real estate services in its consumer price indices, with larger inflation impact.

Still, HKSAR's experience provides several insights for Latvia's adjustment: (i) current account reversal absent nominal exchange rate adjustment is possible; but (ii) severe downward pressure on prices is required for adjustment under a currency board.

Thus, relative to the staff's baseline, there are risks of a deeper and more protracted deflationHKSAR experienced a 141/2 percent fall in CPI over 1998-2004 (and a 21 percent fall in GDP deflator) compared with staff's current projection for Latvia of an 8 percent decline (in both CPI and the GDP deflator) in the coming three years.
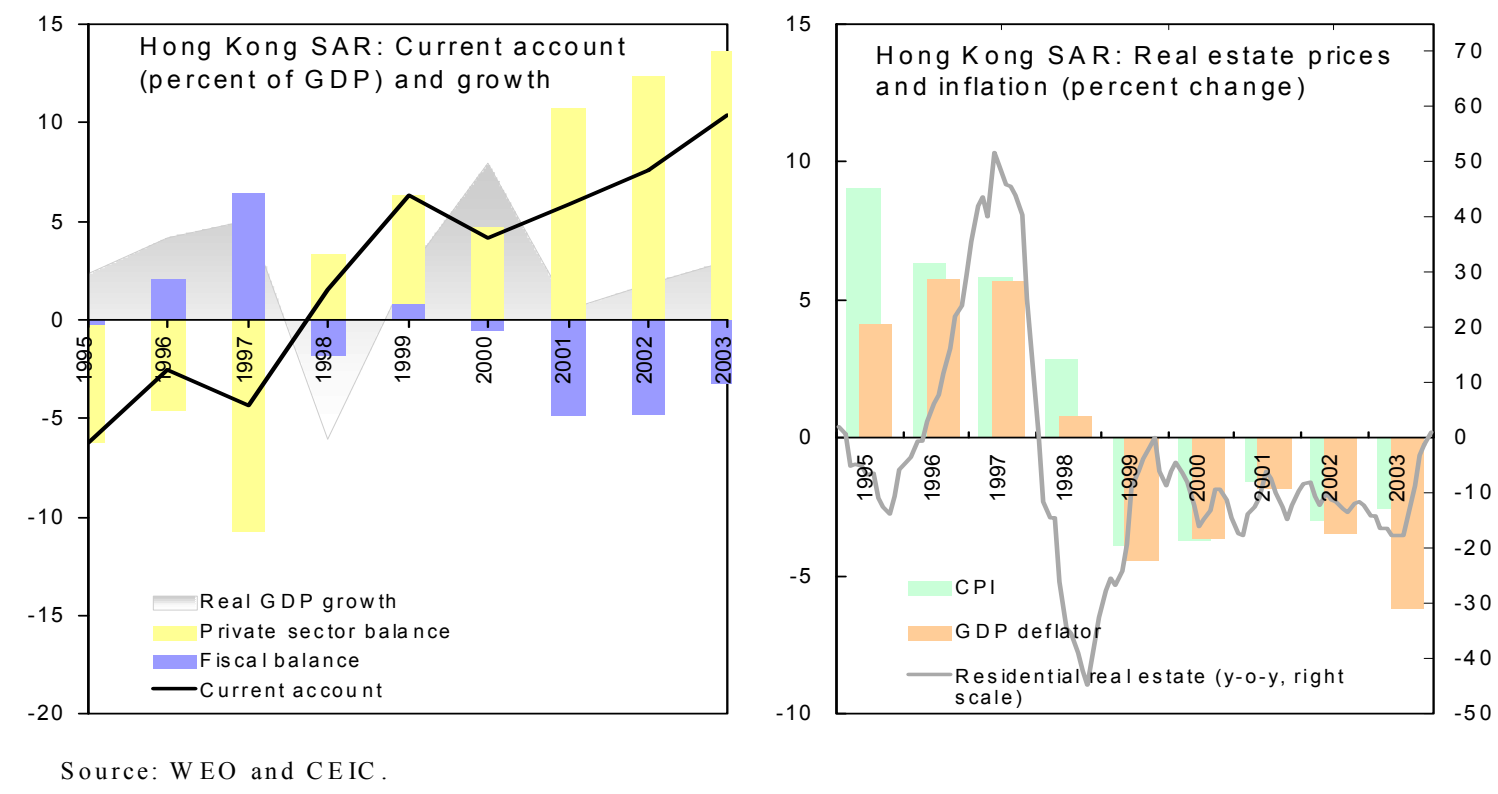

Source: WEO and CEIC 


\section{Box 3: The 2009 Supplementary Budget}

Staff estimates that the 2009 supplementary budget should reduce the budget deficit this year by around $3 \frac{1}{2}$ percent of GDP, with an approximate $61 / 2$ percent of GDP full year effect.

\section{Measures fall into several groups:}

- Recurrent measures (2009 effect: 1.1 percent of GDP): pensions and some social subsidies are cut by 10 percent ( 0.7 percent of GDP) (covers a 3 year period, with renewal every six months) and 70 percent for working pensioners. However, there are thousands of Constitutional Court cases challenging these cuts. The personal income tax allowance is reduced from L90 to L35 (0.3 percent of GDP).

- One-off measures ( 0.6 percent of GDP): increased state-owned enterprise dividends (these have no impact on the overall public sector deficit, revenue effect likely limited given the recession); transfers from the Bank of Latvia; postponing compulsory expenditures to next year (environmental investment) yet including matching funding as 2009 revenue.

- Broadly specified expenditure cuts (3.3 percent of GDP), including a 20 percent cut in the wage bill, likely requiring substantial layoffs. Among the most specified measures, structural reforms in health and education will save about 0.7 percent of GDP.

- Expansionary measures (1.5 percent of GDP), including net lending to and recognition of debt of state-owned enterprises and agencies.

Staff have also excluded the following items:

- Purely accounting measures. This includes the diversion of social security contributions from second pillar pensions funds to the budget to pay for current pensions. Latvian law treats these contributions as the property of the contributors.

- Measures with uncertain effect. This includes likely underestimation of EU-financed capital outlays ( $€ 0.5$ billion of EU funds were used over 2007-09 to finance the deficit, but do not seem to have been used for EU required spending), social spending (in particular in local governments) and interest payments. The budget also likely overestimates non-tax and self-earned revenues.

This analysis is necessarily tentative. The above breakdown represents staff's best estimates, based on available information - derived from budget documentation or other sources - to reconcile policy measures adopted throughout the budget process with the budget's net appropriations. 


\section{Box 4: Specific Issues Raised by Staff Regarding the Supplementary Budget}

\section{Staff have raised a number of specific concerns regarding measures in the 2009 supplementary budget:}

- $\quad$ Education spending will be cut by 50 percent (full-year effect). These reductions could be partially justified if underpinned by structural reforms to consolidate schools and reduce the number of teachers (Latvia has one of the lowest student-teacher ratios in Europe), as recommended by the World Bank. But many municipalities may try to find these savings by lowering teacher wages close to the minimum wage. ${ }^{1}$ The supplementary budget also includes cuts to pre-school preparation for 5- and 6-year olds. In response to concerns of the mission and the World Bank, the latter cuts were scaled back, and integrated into a broader reform that lowers to 6 the age for starting school.

- $\quad$ Health spending will be cut by about one-third (full-year effect), twice the level implied by sustainable reforms designed by the World Bank. The health minister resigned in response, and his successor has questioned the cuts, claiming that by November hospitals will run out of money. Several hospitals could default on loans with commercial banks for which they have received public guarantees.

- The budget provides insufficient resources for existing capital spending commitments, particularly those for which EU funds have already been received but have been used to finance the deficit (about $23 / 4$ percent of GDP since 2007). Failure to implement these projects will cause a build-up of liabilities to the EU, and could reduce disbursements of EU funds in future years.

- Sharply increased dividend payments will deplete the capital of public enterprises, many of which are losing money and will need to borrow to make dividend payments. The authorities also intend to double the share of the Bank of Latvia's profits distributed to the budget. The ECB has suggested that large payouts could dent financial and monetary credibility, and warned that a permanent increase in payout rates could prevent the BoL from maintaining sufficient capital.

- $\quad$ Transfers to municipalities have been cut by $\mathbf{4 5}$ percent, limiting their ability to afford guaranteed minimum income (GMI) payments to people whose unemployment benefits have run out. The authorities agreed that this was a risk (of the order of $1 / 2-1$ percent of GDP), but would use their new power to increase spending in exceptional circumstances to fund this. To address this, the program includes 1 percent of additional resources on social safety nets (LOI \14).

- The main tax increase - a reduction in personal income tax allowances, from $L 70(€ 100)$ to L37 (€55) per month-is regressive. It amounts to a lump sum tax of L13 per month for all workers. Staff estimates that this will increase effective tax rates for the bottom third of the income distribution by 7 percentage points, versus $1 \frac{1}{2}$ percentage points for those in the top 10 percent.

- Pensions are a significant share of income for low-income households. The World Bank strongly recommended smaller pension reductions for lower-income households. Alternatively, the non-taxable threshold for pensions could be reduced (and perhaps combined with a more progressive personal income tax), a potential measure for 2010 .

1/ The World Bank is concerned with both of these measures. The sharp cuts in teacher wages will discourage new entrants to the teaching profession, worsen the quality of education, and undermine long-term growth. Limiting schooling for 5- and 6-year olds will have a regressive impact on poorer families and would be inconsistent with Latvia's objectives of converging with EU levels of educational achievement. 


\section{Box 5: Latvia—Strengthening Bank Resolution Tools}

Best practice calls for supervisors to have the authority and means to intervene in banks well before a crisis erupts. This should help prevent viable banks from deteriorating, and ensure non-viable banks are resolved before they undermine confidence in the rest of the banking system. Bank intervention includes measures to address weaknesses in a bank: (i) pre-emptively even when capital is above regulatory limits; (ii) when capital has fallen below the regulatory minimum but the bank is still solvent; and (iii) when the bank is, or might be, insolvent.

Amendments in February 2009 to the Law on Credit Institutions and the FCMC Law have enhanced the FCMC's intervention tools:

- $\quad$ The FCMC can now replace a bank's management and board with a temporary administrator without court approval, and at an earlier stage of a bank's difficulties.

- $\quad$ Banks can enter purchase and assumption (P\&A) transactions, and transfer assets and liabilities to another entity, without the consent of transferred creditors (i) as a going concern with FCMC approval; (ii) under official administration with the administrator's approval; and (iii) in insolvency (or liquidation) if the administrator (or liquidator) decides.

- $\quad$ The administrator can also seek court approval to liquidate a bank (or parts of it) through an accelerated seven-day process.

Several other recent initiatives have strengthened the resolution framework. The Law on Bank Takeovers, which came into effect in December 2008, is a framework law that permits the government to take over banks either after an agreement (voluntary) or against fair compensation on the basis of a special law (involuntary). Previously, it was thought to be hard or impossible to nationalize banks in Latvia. These powers are nevertheless expected to be used only in exceptional circumstances, such as when financial or payment system stability is threatened. In January 2009 the Bank of Latvia adopted regulations on emergency liquidity support. They widen the range of eligible collateral, establish decision making procedures and roles of relevant agencies, and provide adequate safeguards including stricter supervisory oversight.

Recent deposit insurance reforms will also help reduce the risk of bank runs and minimize disruption in the event of bank failures. Deposit insurance schemes should be funded and operated in such a way that depositors believe the guarantee will be honored, and that they will quickly regain access to their funds. The amendments passed in February and June have the following effects:

- Depositors no longer need to apply for payouts from deposit insurance; these will now occur automatically within 20 days of funds ceasing to be available.

- $\quad$ Pay-outs can now be made by third-party banks (rather than the failed institution).

- $\quad$ Events that could trigger payouts are unambiguously defined in the law

- $\quad$ The FCMC can increase insurance premia after a payout to replenish the fund's resources.

However, the authorities have not yet taken steps to strengthen the deposit guarantee fund's autonomy, nor to ensure that it has designated staff. 


\section{Box 6: Latvia-Corporate and Household Insolvency Reform}

\section{Efficient insolvency procedures are important for resolving corporate and household debt}

distress. They help reduce the disruption caused by over-indebtedness by differentiating viable firms that can be rehabilitated from non-viable firms that need to be liquidated. When wide-scale insolvencies cannot be handled by the court system, a structured framework for out-of-court restructurings becomes critical. Such a framework needs to be supported by insolvency legislation that defines rights and obligations in a balanced, transparent, and predictable manner.

The Latvian authorities have made considerable progress in improving the corporate and household insolvency regime. Amendments to the Insolvency Law, which entered force in July 2009, have two goals: (i) facilitating out-of court restructuring by providing incentives to restructure corporate debt, and (ii) supporting the rehabilitation of household debtors.

\section{The amendments introduce several initiatives to facilitate workouts between viable} corporates and their creditors:

- $\quad$ Modifying the threshold for initiating rehabilitation proceedings to encourage debtors to file when they first run into financial difficulties, as this will increase the chances of successful rehabilitation.

- $\quad$ Lowering the voting threshold for unsecured creditors to approve a rehabilitation plan from two thirds to a simple majority by value of claims. This reduces the risk of dissenting creditors holding up a viable plan.

- $\quad$ Extending the longest rehabilitation period from one year to two years to give financially distressed firms more time to restructure.

- $\quad$ Allowing rehabilitation plans to include principal and interest rate reduction for unsecured creditors to ensure that rehabilitation provides permanent debt relief.

- $\quad$ According priority repayment status to creditors that are willing to provide new financing that will ensure the continued operation of a viable debtor's business - and without which rehabilitation is unlikely to succeed.

- $\quad$ Protecting secured creditors by allowing them to request temporary relief from the stay on enforcement actions if the value of their collateral is falling.

The amendments will also facilitate the rehabilitation of household debtors:

- $\quad$ Filing thresholds have been lowered and administrator fees reduced to make personal insolvency procedures more accessible to middle and low-income households; and

- $\quad$ The repayment plan period has been shortened from seven to five years to strike a more appropriate balance between protecting creditors' interests and the need to give debtors a fresh start. 


\section{Box 7. Proposed Structural Conditionality Under the Stand-By Arrangement}

Latvia's structural benchmarks are designed to help mitigate the impact of the sharp adjustment on the poorest in society, while fostering macroecononomic adjustment and financial sector stability.

\section{Fiscal and Structural Policies}

The strategy to strengthen the social safety net (SB5) will allow the authorities to move forward with the 2010 budget with the benefit of a clear framework to protect the most vulnerable in society. Meanwhile, the amendment on fiscal responsibility (SB7) takes a longer view to help improve budget implementation and focus on medium-term public sector sustainability, critical for program success.

The two benchmarks on wage restraint are intended to help facilitate transparency in the process to support internal devaluation across the economy. Reform of the Committee to Promote Wage Restraint to include social partners and outside labor market experts (SB1) is intended to encourage dialog between the public and private sector, including social partners, to minimize frictions and maximize the demonstration effects of public-sector wage cuts. Meanwhile, the comprehensive report on the revisions to the public-sector wage grid (SB2) will track wage adjustment so far across the public sector and make proposals to limit salary differences across institutions (where appropriate) while ensuring ministries can retain qualified staff.

\section{Financial Sector and Debt Restructuring}

Building on progress in the financial sector to date, by putting in place a strategy for bank recap and resolution (SB3) the authorities will be able to ensure a stronger financial sector while having in place strong contingencies in the event of shocks. Meanwhile, strengthened financial sector monitoring (SB4) through improved stress-testing capabilities and inter-institutional cooperation, with increased resources, will provide the authorities with the information needed to pre-empt financial sector developments. Finally, the submission of amendments to the Insolvency Law and other credit enforcement laws (SB6) will allow for more efficient debt workouts. 
Table 1. Latvia: Selected Economic Indicators, 2007-10

\begin{tabular}{|c|c|c|c|c|c|c|c|}
\hline & \multirow[t]{2}{*}{2007} & \multicolumn{2}{|c|}{2008} & \multicolumn{2}{|c|}{2009} & \multicolumn{2}{|c|}{2010} \\
\hline & & Prog. & Actual & Prog. & Est. & Prog. & Est. \\
\hline Output & \multicolumn{7}{|c|}{ (Annual growth rate, in percent) } \\
\hline Real GDP & 10.0 & -2.0 & -4.6 & -5.0 & -18.0 & -3.0 & -4.0 \\
\hline Private consumption & 14.8 & -6.3 & -11.0 & -7.5 & -25.3 & -6.0 & -8.0 \\
\hline Public consumption & 3.7 & 1.0 & 1.5 & -3.0 & -12.0 & -3.0 & -10.0 \\
\hline Gross fixed investment & 7.5 & -10.0 & -13.2 & -12.0 & -29.0 & -8.5 & -11.5 \\
\hline Stockbuilding (contribution to growth) & 1.6 & 0.0 & -0.6 & -0.1 & 0.0 & 0.0 & 0.0 \\
\hline Exports of goods and services & 9.9 & 4.5 & -1.3 & -3.0 & -15.5 & 2.1 & 1.3 \\
\hline Imports of goods and services & 14.8 & -6.1 & -13.6 & -9.5 & -28.5 & -5.1 & -10.0 \\
\hline Nominal GDP (in billions of euros) & 21.0 & 21.7 & 23.1 & 21.5 & 18.5 & 21.2 & 17.0 \\
\hline \multicolumn{8}{|l|}{ Savings and Investment } \\
\hline Gross national savings (in percent of GDP) & 19.8 & 17.1 & 23.6 & 22.2 & 35.8 & 24.7 & 36.1 \\
\hline Gross capital formation (in percent of GDP) & 40.4 & 30.5 & 34.7 & 27.5 & 29.2 & 27.3 & 27.8 \\
\hline Private investment (in percent of GDP) & 34.9 & 25.5 & 29.7 & 22.8 & 24.5 & 22.6 & 22.6 \\
\hline Net exports (in percent of GDP) & -20.2 & -12.8 & -13.1 & -8.5 & -4.0 & -6.0 & 0.7 \\
\hline \multicolumn{8}{|l|}{ Prices, and employment } \\
\hline HICP (average; in percent) & 10.1 & 15.5 & 15.3 & 5.9 & 3.1 & 2.2 & -3.5 \\
\hline (End-of-period; in percent) & 14.0 & 11.9 & 10.4 & 3.3 & -1.7 & 1.9 & -2.6 \\
\hline Unemployment rate (LFS definition; in percent) $1 /$ & 6.2 & 6.7 & 7.8 & 9.0 & 15.8 & 11.0 & 17.4 \\
\hline Real gross wages $1 /$ & 19.7 & 5.2 & 4.4 & -4.6 & -14.6 & -5.4 & -4.7 \\
\hline Consolidated general government $2 /$ & \multicolumn{7}{|c|}{ (In percent of GDP) } \\
\hline Revenue & 36.2 & 38.0 & 35.2 & 34.8 & 35.3 & 36.6 & 35.6 \\
\hline Expenditure and net lending & 35.6 & 41.1 & 38.5 & 39.8 & 48.4 & 41.4 & 47.6 \\
\hline Basic fiscal balance & 0.7 & -3.0 & -3.3 & -4.9 & -13.0 & -4.9 & -12.0 \\
\hline General government gross debt & 7.8 & 14.3 & 17.0 & 33.7 & 43.5 & 46.0 & 74.2 \\
\hline Credit and deposits & \multicolumn{7}{|c|}{ (Annual percent change, unless otherwise stated) } \\
\hline Credit to private sector & 34.0 & 13.0 & 11.8 & -0.9 & -4.8 & $\ldots$ & $\ldots$ \\
\hline Residents' FX deposits (in billions of euros) & 3.7 & $\ldots$ & 4.3 & $\ldots$ & $\ldots$ & $\ldots$ & $\ldots$ \\
\hline Residents' FX deposits (percent of M2X) & 41.7 & $\ldots$ & 51.1 & $\ldots$ & $\ldots$ & $\ldots$ & $\ldots$ \\
\hline \multicolumn{8}{|l|}{ Interest rates (eop, annualized) } \\
\hline BoL refinancing rate & 6.0 & $\ldots$ & 6.0 & $\ldots$ & $\ldots$ & $\ldots$ & ... \\
\hline Money market (one month) & 6.8 & $\cdots$ & 13.3 & $\cdots$ & $\cdots$ & $\cdots$ & $\cdots$ \\
\hline Balance of payments & \multicolumn{7}{|c|}{ (In percent of GDP, unless otherwise stated) } \\
\hline Gross official reserves (in billions of euros) & 3.966 & 3.720 & 3.697 & 3.386 & 3.392 & 4.741 & 4.397 \\
\hline (In months of prospective imports of GNFS) & 3.8 & 4.0 & 6.3 & 3.8 & 6.3 & 5.1 & 7.6 \\
\hline (in percent of $\mathrm{M} 2 \mathrm{X}$ and non-resident deposits) & 21.8 & $\ldots$ & 23.5 & $\cdots$ & 26.0 & $\cdots$ & 35.5 \\
\hline Current account balance & -22.5 & -14.8 & -12.6 & -7.3 & 4.5 & -5.5 & 6.4 \\
\hline Trade balance & -23.9 & -18.0 & -17.0 & -12.5 & -8.3 & -10.8 & -5.6 \\
\hline Exports of goods and services & 41.2 & 45.3 & 41.4 & 44.8 & 36.6 & 45.6 & 32.2 \\
\hline Imports of goods and services & -61.8 & -59.2 & -54.4 & -52.0 & -38.0 & -50.5 & -31.8 \\
\hline Gross external debt & 126.8 & 129.3 & 126.9 & 138.2 & 160.8 & 143.2 & 171.3 \\
\hline Net external debt 3/ & 48.2 & 56.0 & 56.0 & 65.7 & 65.7 & 63.7 & 67.0 \\
\hline \multicolumn{8}{|l|}{ Exchange rates } \\
\hline Lats per U.S. dollar (Annual average) & 0.513 & $\ldots$ & 0.478 & $\ldots$ & $\ldots$ & $\ldots$ & $\ldots$ \\
\hline (yoy percent change, + means appreciation) & 9.2 & $\ldots$ & 7.4 & $\ldots$ & $\ldots$ & $\ldots$ & $\ldots$ \\
\hline REER (annual average; CPI based, 2000=100) & 100.1 & $\ldots$ & 111.3 & $\ldots$ & $\ldots$ & $\ldots$ & $\ldots$ \\
\hline (yoy percent change, + means appreciation) & 8.0 & $\cdots$ & 11.1 & $\cdots$ & $\cdots$ & $\cdots$ & $\cdots$ \\
\hline \multicolumn{8}{|l|}{ Nominal GDP } \\
\hline Nominal GDP (in billions of Latvian lats) & 14.8 & 15.3 & 16.2 & 15.1 & 13.0 & 14.9 & 11.9 \\
\hline Nominal GDP (in billions of euros) & 21.0 & 21.7 & 23.1 & 21.5 & 18.5 & 21.2 & 17.0 \\
\hline GDP per capita (in euros) & 9,216 & 9,565 & 10,175 & 9,487 & 8,163 & 9,398 & 7,521 \\
\hline
\end{tabular}

Sources: Latvian authorities; Eurostat; and IMF staff estimates.

1/ Year-average.

2/ National definition. Includes economy-wide EU grants in revenue and expenditure. Program scenario.

$3 /$ Gross external debt liabilities minus gross external debt assets and international reserves. 
Table 2. Bank of Latvia Balance Sheet 2005-10

(End-period; at program exchange rates, in millions of lats unless otherwise stated)

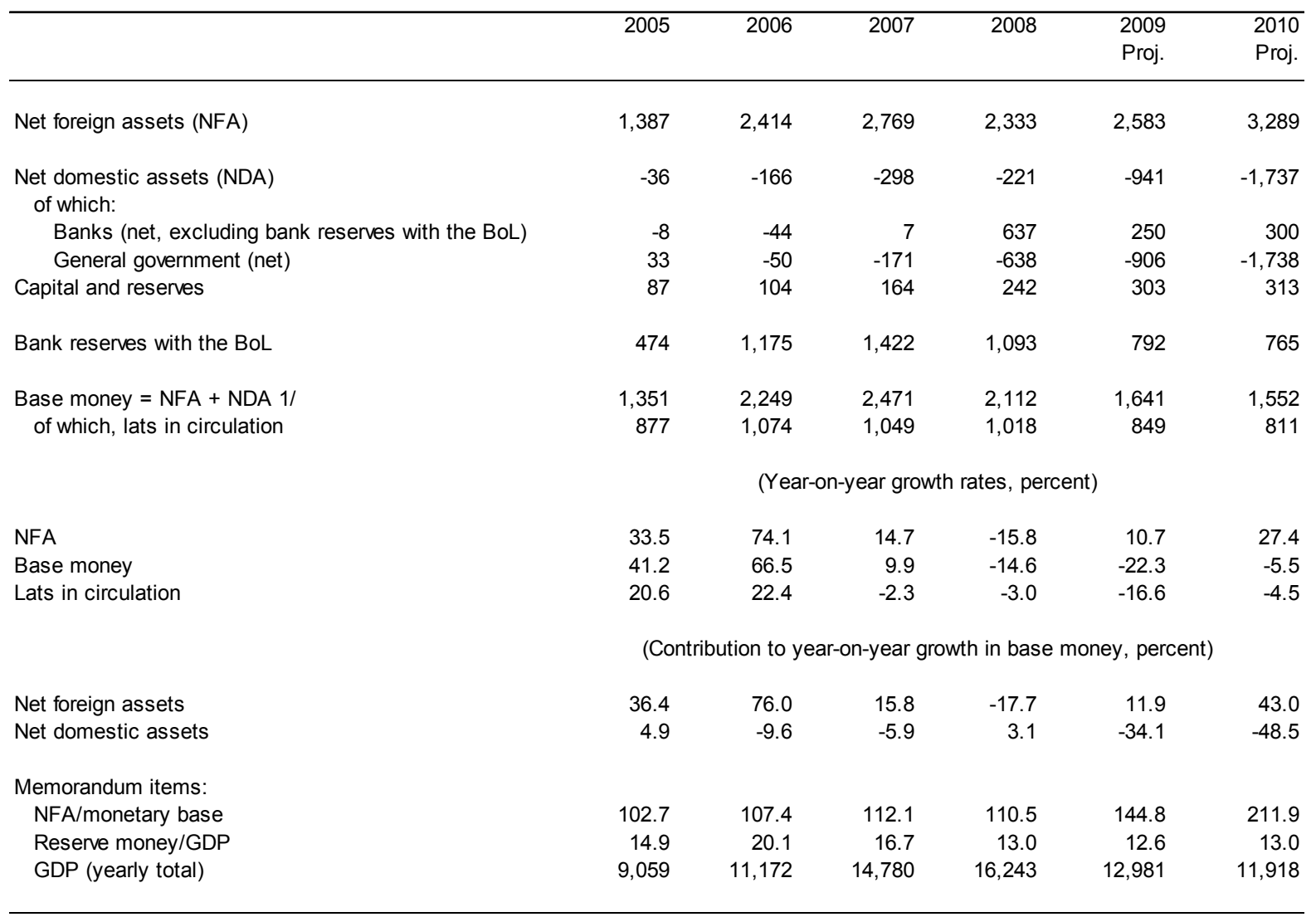

Source: Bank of Latvia and IMF staff estimates and projections.

1/ Excludes banks' deposits at deposit facility. 
Table 3. Latvia: Monetary Survey, 2006-10

(End-period; in millions of lats unless otherwise stated)

\begin{tabular}{|c|c|c|c|c|c|c|c|}
\hline & \multirow[t]{2}{*}{2006} & \multirow[t]{2}{*}{2007} & \multirow[t]{2}{*}{2008} & \multicolumn{3}{|c|}{2009} & \multirow{2}{*}{$\begin{array}{l}2010 \\
\text { Proj . }\end{array}$} \\
\hline & & & & June & Prog. & Proj. & \\
\hline & \multicolumn{7}{|c|}{ (At current exchange rates) } \\
\hline Net foreign assets (NFA) & $-2,635$ & $-4,483$ & $-5,915$ & $-4,433$ & $-5,859$ & $-3,865$ & $-2,048$ \\
\hline Bank of Latvia & 2,414 & 2,769 & 2,332 & 2,285 & 2,187 & 2,583 & 3,289 \\
\hline Domestic money banks & $-5,049$ & $-7,252$ & $-8,247$ & $-6,718$ & $-8,046$ & $-6,447$ & $-5,338$ \\
\hline Net domestic assets (NDA) & 8,115 & 10,654 & 11,846 & 10,189 & 11,894 & 9,669 & 7,968 \\
\hline Domestic credit & 9,877 & 13,018 & 14,280 & 13,158 & 14,593 & 12,930 & 11,814 \\
\hline Credit to private sector & 9,777 & 13,106 & 14,650 & 14,095 & 14,674 & 13,947 & 13,462 \\
\hline Government, net & 101 & -87 & -370 & -937 & -81 & $-1,017$ & $-1,649$ \\
\hline Other Items, net & $-1,763$ & $-2,364$ & $-2,434$ & $-2,969$ & $-2,699$ & $-3,261$ & $-3,846$ \\
\hline Broad money & 5,480 & 6,171 & 5,931 & 5,756 & 6,035 & 5,804 & 5,919 \\
\hline Domestic money supply (M2) & 3,620 & 3,630 & 3,468 & 2,832 & 3,773 & 2,806 & 2,802 \\
\hline Currency held by public & 969 & 900 & 866 & 699 & 936 & 742 & 704 \\
\hline Private deposits in lats & 2,651 & 2,730 & 2,602 & 2,133 & 2,837 & 2,064 & 2,098 \\
\hline Monetary base & 2,249 & 2,471 & 2,112 & 1,612 & 1,796 & 1,641 & 1,552 \\
\hline Total domestic deposits & 4,511 & 5,271 & 5,065 & 5,057 & 5,139 & 5,062 & 5,215 \\
\hline of which, residents' foreign currency deposits & 1,860 & 2,541 & 2,463 & 2,924 & 2,302 & 2,998 & 3,117 \\
\hline Non resident non-bank deposits & 3,017 & 4,513 & 3,463 & 2,868 & 3,071 & 2,763 & 2,171 \\
\hline \multirow[t]{2}{*}{ Total foreign currency deposits } & 4,877 & 7,054 & 5,927 & 5,791 & 5,373 & 5,761 & 5,288 \\
\hline & \multicolumn{7}{|c|}{ (Year-on-year growth rates, percent) } \\
\hline Credit to private sector & 58.3 & 34.0 & 11.8 & 2.7 & -0.9 & -4.8 & -3.5 \\
\hline Broad money & 37.5 & 12.6 & -3.9 & -7.4 & -3.0 & -2.1 & 2.0 \\
\hline Private deposits in lats & 39.6 & 3.0 & -4.7 & -25.2 & 0.2 & -20.7 & 1.6 \\
\hline Foreign currency deposits & 15.4 & 44.7 & -16.0 & -26.6 & -12.2 & -2.8 & -8.2 \\
\hline \multicolumn{8}{|l|}{ Memorandum items: } \\
\hline Broad money/GDP & 49.1 & 41.8 & 36.5 & 44.3 & 40.0 & 44.7 & 49.7 \\
\hline Residents' foreign currency deposits/total domestic deposits & 41.2 & 48.2 & 48.6 & 57.8 & 44.8 & 59.2 & 59.8 \\
\hline Broad money multiplier (broad money/reserve money) & 2.4 & 2.5 & 2.8 & 3.6 & 3.4 & 3.5 & 3.8 \\
\hline Private credit (percent of GDP) & 87.5 & 88.7 & 90.2 & 108.6 & 97.2 & 107.4 & 113.0 \\
\hline GDP (yearly total) & 11,172 & 14,780 & 16,243 & 12,981 & 15,091 & 12,981 & 11,918 \\
\hline
\end{tabular}

Source: Bank of Latvia and IMF staff estimates and projections. 
Table 4. Latvia: Financial Soundness Indicators, 2007-09

(In percent, unless otherwise indicated)

\begin{tabular}{|c|c|c|c|c|c|c|c|c|}
\hline & Dec-07 & Jun-08 & Dec-08 & Jan-09 & Feb-09 & Mar-09 & Apr-09 & May-09 7/ \\
\hline \multicolumn{9}{|l|}{ Commercial banks } \\
\hline \multicolumn{9}{|l|}{ Capital Adequacy } \\
\hline Regulatory capital to risk-w eighted assets & 11.1 & 12.2 & 11.8 & 12.5 & 12.3 & 11.4 & 11.0 & 12.8 \\
\hline Regulatory Tier I capital to risk-w eighted assets & 9.8 & 11.1 & 10.5 & 11.1 & 10.9 & 10.8 & 10.4 & 11.2 \\
\hline Capital and reserves to assets & 7.9 & 8.2 & 7.3 & 7.6 & 7.6 & 7.5 & 7.4 & 7.8 \\
\hline \multicolumn{9}{|l|}{ Asset Quality } \\
\hline Annual grow th of bank loans & 37.2 & 21.1 & 11.2 & 11.5 & 9.8 & 7.9 & 5.6 & 2.5 \\
\hline Loans past due over 30 days & & 3.9 & 7.8 & 9.2 & 10.9 & 13.1 & 14.0 & 15.5 \\
\hline Loans past due over 90 days & 0.8 & 2.1 & 3.6 & 4.6 & 5.7 & 7.1 & 9.0 & 10.7 \\
\hline Loans past due over 90 days net of loan loss provisions to capital & & 11.8 & 13.6 & 20.3 & 29.0 & 36.4 & 52.1 & 59.4 \\
\hline Loan loss provisions to loans past due over 90 days & & 34.1 & 61.3 & 53.3 & 47.0 & 48.0 & 42.1 & 40.7 \\
\hline Share of loans in total assets, banks dealing with residents $1 /$ & 80.4 & 81.2 & 82.5 & 82.6 & 82.6 & 82.4 & 82.0 & 77.4 \\
\hline Share of loans in total assets, banks dealing with non-residents $1 /$ & 48.9 & 52.5 & 51.7 & 52.0 & 53.1 & 58.6 & 58.1 & 56.3 \\
\hline \multicolumn{9}{|l|}{ Earnings and Profitability } \\
\hline ROA (after tax) & 2.0 & 1.5 & 0.3 & 0.4 & -0.2 & -0.9 & -1.2 & -1.6 \\
\hline $\mathrm{ROE}$ (after tax) & 24.3 & 17.7 & 4.6 & 4.7 & -4.0 & -11.2 & -14.3 & -19.7 \\
\hline Net interest income to total income & 32.5 & 30.3 & 30.1 & 27.9 & 26.8 & 24.8 & 25.1 & 25.6 \\
\hline Noninterest expenses to total income & 32.3 & 34.6 & 47.5 & 46.2 & 55.0 & 68.2 & 73.5 & 79.6 \\
\hline Trading income to total income & 7.8 & 7.2 & 5.6 & 1.5 & 4.0 & 3.9 & 5.6 & 6.8 \\
\hline Personnel expenses to noninterest expenses & 31.5 & 30.1 & 21.3 & 20.0 & 17.2 & 13.2 & 12.9 & 12.2 \\
\hline \multicolumn{9}{|l|}{ Income from operations with non-residents to total income } \\
\hline Banks dealing $w$ ith residents $1 /$ & 13.0 & 12.4 & 13.7 & 37.9 & 23.1 & 19.4 & 19.3 & 23.4 \\
\hline Banks dealing with non-residents $1 /$ & 49.2 & 46.3 & 48.0 & 62.4 & 63.9 & 44.9 & 45.3 & 50.3 \\
\hline \multicolumn{9}{|l|}{ Liquidity } \\
\hline Liquid assets to total assets & 25.0 & 21.8 & 21.6 & 20.3 & 19.7 & 18.6 & 19.1 & 19.5 \\
\hline Liquid assets to short term liabilities & 55.7 & 50.7 & 52.8 & 48.9 & 46.8 & 48.0 & 48.9 & 50.2 \\
\hline Customers deposits to (non-interbank) loans & 68.2 & 64.7 & 58.8 & 57.6 & 57.7 & 58.9 & 59.9 & 57.9 \\
\hline \multicolumn{9}{|l|}{ Sensitivity to Market Risk } \\
\hline Net open positions in FX to capital 2/ & 5.4 & 3.7 & 6.3 & $\ldots$ & $\ldots$ & $3.18 /$ & $\ldots$ & $\cdots$ \\
\hline Net open positions in EUR to capital & 3.2 & 1.7 & 3.7 & $\ldots$ & $\ldots$ & $2.68 /$ & $\ldots$ & $\ldots$ \\
\hline FX assets to total assets & 79.7 & 80.2 & 80.5 & 81.0 & 81.3 & 82.1 & 82.6 & 82.6 \\
\hline FX deposits to total deposits & 70.7 & 69.1 & 69.4 & 69.7 & 69.9 & 71.5 & 71.7 & 73.4 \\
\hline FX liabilities to total liabilities $2 /$ & 81.7 & 81.0 & 81.1 & 81.2 & 80.9 & 81.8 & 81.8 & 82.5 \\
\hline FX loans to total loans 2 / & 81.8 & 82.5 & 85.0 & 85.6 & 85.1 & 85.5 & 86.7 & 87.0 \\
\hline \multicolumn{9}{|l|}{ Nonfinancial Enterprises 3 / } \\
\hline Total debt to equity & 202.0 & 172.5 & $\ldots$ & $\ldots$ & $\ldots$ & 175.6 & $\cdots$ & $\cdots$ \\
\hline Return on equity & 31.1 & 10.1 & $\ldots$ & $\ldots$ & $\ldots$ & 1.6 & $\cdots$ & $\cdots$ \\
\hline Earnings to interest expenses & 496.7 & 414.7 & 321.3 & $\ldots$ & $\cdots$ & 117.8 & $\cdots$ & ... \\
\hline \multicolumn{9}{|l|}{ Households } \\
\hline Household debt to GDP & 42.4 & 41.3 & 41.3 & $\ldots$ & $\ldots$ & 42.4 & $\ldots$ & ... \\
\hline Household debt service to GDP 4/ & 2.5 & 2.7 & 2.7 & $\cdots$ & $\cdots$ & 2.7 & $\cdots$ & $\cdots$ \\
\hline \multicolumn{9}{|l|}{ Real Estate Markets } \\
\hline Real estate prices annual grow th rate $5 /$ & -7.3 & -27.2 & -37.1 & -40.6 & -48.4 & -52.0 & -56.6 & -58.4 \\
\hline Residential real estate loans to total loans $6 /$ & 31.6 & 31.0 & 30.5 & 30.4 & 30.4 & 30.5 & 30.6 & 30.8 \\
\hline Commercial real estate loans to total loans $6 /$ & 17.8 & 19.8 & 19.5 & 19.4 & 19.4 & 19.4 & 19.4 & 19.2 \\
\hline \multicolumn{9}{|l|}{ Memorandum Items } \\
\hline Number of banks dealing $w$ ith residents $1 /$ & 9 & 12 & 13 & 14 & 14 & 12 & 12 & 14 \\
\hline Number of banks dealing $w$ ith non-residents $1 /$ & 14 & 13 & 13 & 12 & 12 & 14 & 14 & 12 \\
\hline Assets of banks dealing with residents/Total banking system assets $1 /$ & 60.8 & 64.8 & 63.9 & 66.3 & 66.8 & 63.9 & 63.9 & 78.3 \\
\hline Assets of banks dealing $w$ ith non-residents/Total banking system assets $1 /$ & 39.2 & 35.2 & 36.1 & 33.7 & 33.2 & 36.1 & 36.1 & 21.7 \\
\hline
\end{tabular}

Source: CSB, BoL, FCMC, Latvian Leasing Association, staff calculations

1/ Banks dealing with residents (non-residents) are defined as banks in w hich non-resident non-MFI deposits are below (above) 20 percent of their assets.

2/ Including euro-denominated positions.

3/ Data for 2008 is not annualized and not comparable to yearly figures due to different sample (for 6 and 9 months respectively ); ROE for 2008 based on quarterly data sample, not annualized

4/ Interest payments only.

5/ Prices of typical serial apartments in Riga. Source: Real estate company Latio

6/ Loans to residents only to total loans (including loans to non-residents).

7/ Preliminary data.

8/ Excluding Parex Bank. 
Table 5. Latvia. Macroeconomic Framework, 2007-14

(Percentage change, unless otherwise indicated)

\begin{tabular}{|c|c|c|c|c|c|c|c|c|}
\hline & 2007 & 2008 & 2009 & 2010 & 2011 & 2012 & 2013 & 2014 \\
\hline & & & \multicolumn{6}{|c|}{ Projections } \\
\hline \multicolumn{9}{|l|}{ Output and demand } \\
\hline Real GDP & 10.0 & -4.6 & -18.0 & -4.0 & 1.5 & 3.8 & 3.9 & 4.0 \\
\hline Consumption & 12.9 & -9.0 & -22.9 & -8.4 & -0.2 & 2.6 & 2.8 & 2.8 \\
\hline Private consumption & 14.8 & -11.0 & -25.3 & -8.0 & 0.3 & 3.2 & 3.0 & 3.0 \\
\hline Public consumption & 3.7 & 1.5 & -12.0 & -10.0 & -2.0 & 0.0 & 2.0 & 2.0 \\
\hline Gross fixed capital formation & 7.5 & -13.2 & -29.0 & -11.5 & 1.0 & 7.0 & 6.0 & 6.3 \\
\hline Exports of goods and services & 9.9 & -1.3 & -15.5 & 1.3 & 4.4 & 5.8 & 5.6 & 5.7 \\
\hline Imports of goods and services & 14.8 & -13.6 & -28.5 & -10.0 & 1.5 & 5.4 & 5.0 & 5.1 \\
\hline \multicolumn{9}{|l|}{ Contributions to growth } \\
\hline Domestic demand & 15.2 & -13.0 & -28.3 & -9.8 & 0.1 & 3.7 & 3.6 & 3.7 \\
\hline Net exports & -5.2 & 8.5 & 10.3 & 5.8 & 1.3 & 0.2 & 0.3 & 0.3 \\
\hline & \multicolumn{8}{|c|}{ (In percent of GDP) } \\
\hline \multicolumn{9}{|l|}{ Fiscal sector $1 /$} \\
\hline General government revenues & 36.2 & 35.2 & 35.3 & 35.6 & 35.6 & 35.7 & 36.8 & 36.8 \\
\hline General government expenditure & 35.6 & 38.5 & 48.4 & 47.6 & 45.1 & 43.2 & 41.8 & 39.8 \\
\hline Basic Balance & 0.7 & -3.3 & -13.0 & -12.0 & -9.5 & -7.5 & -5.0 & -3.0 \\
\hline Balance (including bank restructuring costs) & 0.7 & -7.4 & -20.8 & -19.8 & -16.7 & -7.5 & -5.0 & -3.0 \\
\hline General government gross debt & 7.8 & 17.0 & 43.5 & 74.2 & 87.2 & 89.2 & 90.0 & 88.6 \\
\hline \multicolumn{9}{|l|}{ Savings and investment } \\
\hline Domestic saving & 19.8 & 23.6 & 35.8 & 36.1 & 35.2 & 36.0 & 36.0 & 35.9 \\
\hline Private & 12.8 & 20.2 & 41.9 & 41.1 & 37.9 & 37.0 & 34.3 & 32.3 \\
\hline Public 2/ & 7.0 & 3.4 & -6.1 & -5.0 & -2.7 & -1.0 & 1.7 & 3.6 \\
\hline Foreign saving $3 /$ & 20.6 & 11.2 & -6.6 & -8.3 & -7.1 & -6.9 & -6.5 & -6.1 \\
\hline Investment & 40.4 & 34.7 & 29.2 & 27.8 & 28.2 & 29.0 & 29.5 & 29.8 \\
\hline Private & 34.9 & 29.7 & 24.5 & 22.6 & 23.1 & 24.3 & 24.5 & 24.9 \\
\hline Public & 5.5 & 5.1 & 4.7 & 5.2 & 5.0 & 4.8 & 5.0 & 5.0 \\
\hline \multicolumn{9}{|l|}{ External sector } \\
\hline Current account balance & -22.5 & -12.6 & 4.5 & 6.4 & 5.1 & 4.9 & 4.6 & 4.1 \\
\hline Net IIP & 74.2 & 82.6 & 102.2 & 110.4 & 103.4 & 91.7 & 80.7 & 70.6 \\
\hline \multicolumn{9}{|l|}{ External debt } \\
\hline Gross & 126.8 & 126.9 & 160.8 & 171.3 & 174.9 & 169.8 & 164.0 & 157.5 \\
\hline Net 4/ & 48.2 & 56.0 & 65.7 & 67.0 & 56.6 & 42.5 & 28.9 & 16.3 \\
\hline \multicolumn{9}{|l|}{ HICP inflation } \\
\hline Period average (in percent) & 10.1 & 15.3 & 3.1 & -3.5 & -2.5 & 0.2 & 0.9 & 1.1 \\
\hline End-period (in percent) & 14.0 & 10.4 & -1.7 & -2.6 & -1.6 & 1.6 & 1.3 & 1.1 \\
\hline \multicolumn{9}{|l|}{ Labor market } \\
\hline Unemployment (period average, in percent) & 6.2 & 7.8 & 15.8 & 17.4 & 16.9 & 16.3 & 15.3 & 14.4 \\
\hline Employment (period average, percent change) & 2.7 & 0.1 & -7.9 & -3.9 & -1.0 & 0.0 & 0.5 & 0.5 \\
\hline Real gross wages & 19.7 & 4.4 & -14.6 & -4.7 & 2.3 & 1.5 & 0.9 & 1.3 \\
\hline \multicolumn{9}{|l|}{ Memorandum items } \\
\hline Gross official reserves (in billions of euros) & 4.0 & 3.7 & 3.4 & 4.4 & 5.7 & 7.0 & 8.0 & 9.2 \\
\hline Nominal GDP (in billions of lats) & 14.8 & 16.2 & 13.0 & 11.9 & 11.9 & 12.5 & 13.1 & 13.8 \\
\hline Nominal GDP (in billions of euro) & 21.0 & 23.1 & 18.5 & 17.0 & 16.9 & 17.7 & 18.6 & 19.6 \\
\hline
\end{tabular}

Sources: Latvian Authorities, Fund Staff Calculations.

1/ Program scenario.

2/ Includes 2nd pillar contributions. Accrual basis.

3/ Defined as the sum of the current account deficit and capital transfers.

4/ Gross external debt liabilities minus gross external debt assets and international reserves. 
Table 6. Latvia: Medium Term Balance of Payments, 2007-14 (In millions of euros)

\begin{tabular}{|c|c|c|c|c|c|c|c|c|c|c|}
\hline & \multirow[t]{2}{*}{2007} & \multicolumn{2}{|c|}{2008} & \multicolumn{2}{|c|}{2009} & 2010 & 2011 & 2012 & 2013 & 2014 \\
\hline & & Prog. & Est. & Prog. & Proj. & \multicolumn{5}{|c|}{ Projections } \\
\hline Current account & $-4,734$ & $-3,217$ & $-2,919$ & $-1,566$ & 832 & 1,080 & 858 & 877 & 848 & 805 \\
\hline Trade balance (fob) & $-5,032$ & $-3,917$ & $-3,921$ & $-2,689$ & $-1,537$ & -953 & $-1,014$ & $-1,048$ & $-1,118$ & $-1,225$ \\
\hline Exports & 5,997 & 6,741 & 6,474 & 6,573 & 4,165 & 4,268 & 4,652 & 5,058 & 5,447 & 5,889 \\
\hline Imports & 11,028 & 10,658 & 10,395 & 9,263 & 5,702 & 5,221 & 5,667 & 6,106 & 6,565 & 7,115 \\
\hline Services & 706 & 899 & 926 & 1,132 & 1,278 & 1,488 & 1,621 & 1,754 & 1,900 & 2,016 \\
\hline Credit & 2,671 & 3,093 & 3,100 & 3,039 & 2,589 & 2,689 & 2,875 & 3,067 & 3,252 & 3,449 \\
\hline Debit & 1,966 & 2,194 & 2,174 & 1,907 & 1,312 & 1,201 & 1,254 & 1,313 & 1,352 & 1,433 \\
\hline Income & -684 & -650 & -436 & -470 & 724 & 175 & -121 & -219 & -344 & -418 \\
\hline Investment income & $-1,057$ & $-1,021$ & -808 & -815 & 356 & -169 & -403 & -514 & -654 & -744 \\
\hline of which: net interest payments & -224 & & -367 & & -469 & -626 & -271 & -336 & -369 & -370 \\
\hline Compensation of employees & 373 & 371 & 372 & 345 & 368 & 344 & 281 & 295 & 310 & 326 \\
\hline Current transfers & 276 & 451 & 512 & 461 & 367 & 370 & 373 & 390 & 410 & 431 \\
\hline Capital and financial account & 5,595 & 2,198 & 1,956 & $-2,168$ & $-4,230$ & $-3,064$ & -6 & 1,411 & 1,612 & 1,729 \\
\hline Capital account & 410 & 317 & 340 & 415 & 380 & 320 & 336 & 353 & 370 & 389 \\
\hline Financial account (net) & 5,185 & 1,881 & 1,616 & $-2,583$ & $-4,610$ & $-3,384$ & -342 & 1,059 & 1,242 & 1,340 \\
\hline Direct investment & 1,411 & 1,046 & 772 & 229 & 213 & 424 & 626 & 921 & 1,033 & 1,116 \\
\hline Portfolio investment & -493 & 262 & 168 & -295 & 218 & 160 & -13 & -14 & -15 & -15 \\
\hline Financial derivatives & 164 & 114 & -72 & 114 & 249 & 0 & 0 & 0 & 0 & 0 \\
\hline Other investment & 4,103 & 458 & 749 & $-2,631$ & $-5,290$ & $-3,968$ & -955 & 151 & 224 & 239 \\
\hline Trade credit & 70 & -222 & -428 & -163 & -160 & -127 & -40 & -46 & -40 & -42 \\
\hline MLT borrowing (net) & 3,762 & 1,867 & 2,878 & $-1,196$ & $-1,444$ & $-1,143$ & -557 & 1,115 & 1,598 & 1,274 \\
\hline o/w foreign borrowing & $\ldots$ & 1,807 & 2,818 & $-1,196$ & $-1,066$ & $-1,143$ & -842 & 269 & 293 & 310 \\
\hline Disbursements & $\ldots$ & 5,467 & 5,467 & 1,184 & 1,174 & 2,554 & 4,507 & 5,641 & 6,157 & 6,519 \\
\hline Amortization & 2,243 & 3,661 & 2,649 & 2,380 & 2,241 & 3,697 & 5,349 & 5,373 & 5,864 & 6,208 \\
\hline ST borrowing (net) & 218 & $-1,312$ & $-1,343$ & $-1,311$ & $-4,013$ & $-2,709$ & -368 & -969 & $-1,426$ & $-1,043$ \\
\hline o/w nonresident deposits & $\ldots$ & $-1,071$ & $-1,376$ & $-1,158$ & $-1,047$ & -843 & -54 & -53 & -26 & -26 \\
\hline Other & 54 & 35 & -17 & 40 & -33 & 10 & 10 & 10 & 10 & 10 \\
\hline Errors and omissions & -147 & -327 & -435 & 0 & -41 & 0 & 0 & 0 & 0 & 0 \\
\hline Overall balance & 714 & $-1,346$ & $-1,398$ & $-3,734$ & $-3,438$ & $-1,985$ & 852 & 2,288 & 2,460 & 2,534 \\
\hline Official financing (net) $1 /$ & 0 & 500 & 360 & 2,800 & 2,740 & 2,400 & 300 & -456 & -813 & -915 \\
\hline Financing & -714 & 846 & 1,038 & 934 & 698 & -415 & $-1,152$ & $-1,832$ & $-1,648$ & $-1,619$ \\
\hline Change in reserve assets (increase:-) & -714 & 246 & 456 & 334 & 305 & $-1,005$ & $-1,255$ & $-1,395$ & -973 & $-1,219$ \\
\hline IMF (net) & 0 & 600 & 582 & 600 & 394 & 590 & 104 & -438 & -675 & -400 \\
\hline Purchases & 0 & 600 & 582 & 600 & 394 & 590 & 104 & 0 & 0 & 0 \\
\hline Repurchases & 0 & 0 & 0 & 0 & 0 & 0 & 0 & 438 & 675 & 400 \\
\hline
\end{tabular}

Sources: Latvian authorities and IMF staff estimates and projections.

1/ 2008 official financing includes short term central bank bridge loan. This bridge loan was set at EUR 500 million, though the authorities only drew EUR 360 million. Since this is short term, it is netted out of 2009 official financing as it is repaid. 
Table 6. Latvia: Medium Term Balance of Payments, 2007-14, (Concluded)

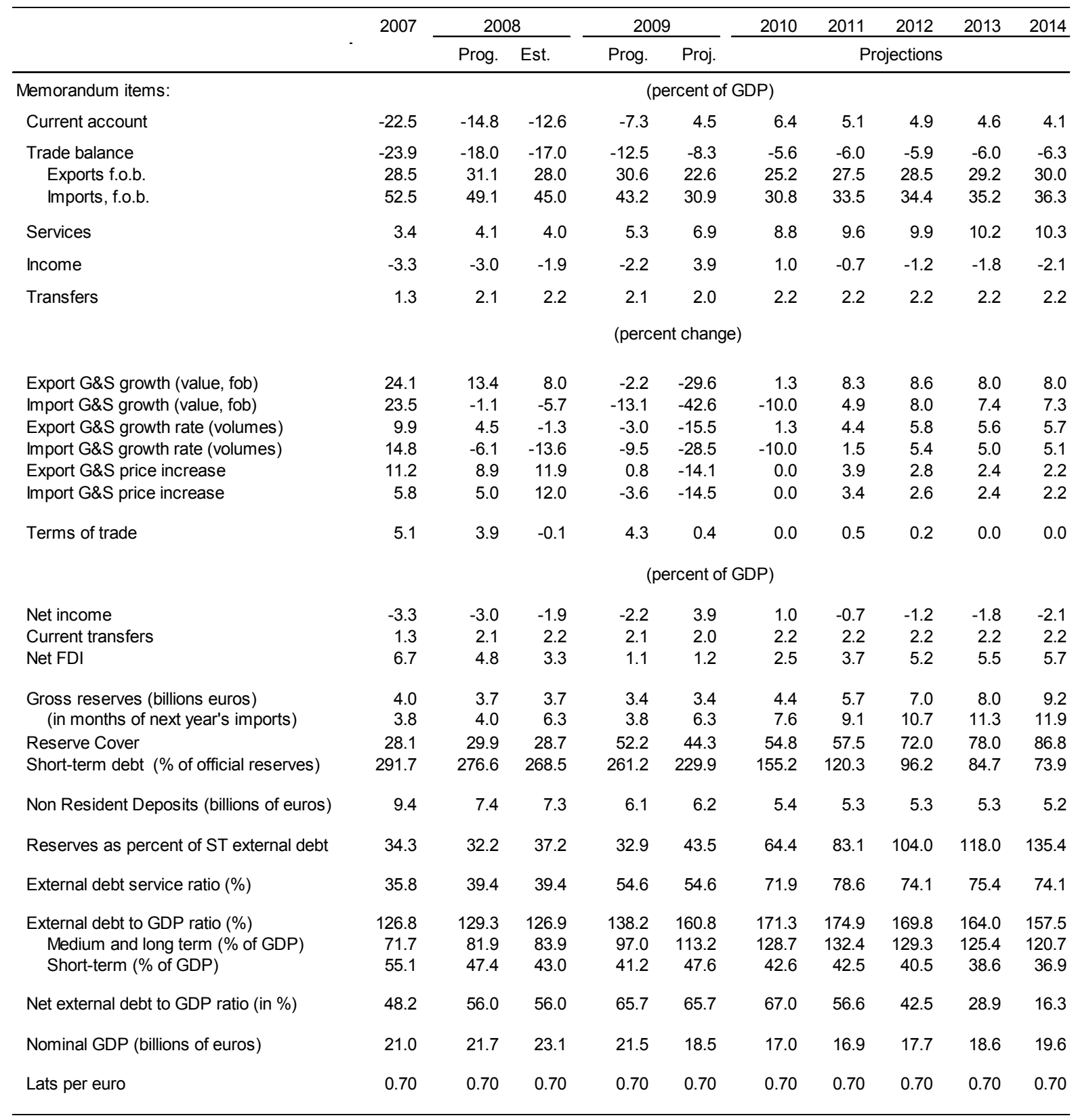

Sources: Latvian authorities and IMF staff estimates and projections. 
Table 7. Latvia: External debt dynamics

\begin{tabular}{|c|c|c|c|c|c|c|c|c|}
\hline & 2007 & 2008 & 2009 & 2010 & 2011 & 2012 & 2013 & 2014 \\
\hline & \multicolumn{8}{|c|}{ (billions euros) } \\
\hline Gross external debt & 26.6 & 29.3 & 29.7 & 29.0 & 29.6 & 30.1 & 30.6 & 30.9 \\
\hline Public & 1.1 & 2.5 & 5.4 & 8.6 & 9.3 & 9.0 & 8.6 & 7.7 \\
\hline Private & 25.5 & 26.8 & 24.3 & 20.4 & 20.3 & 21.1 & 22.0 & 23.2 \\
\hline Banks & 18.0 & 18.5 & 16.3 & 13.5 & 13.1 & 13.5 & 14.1 & 14.9 \\
\hline Long term & 8.1 & 10.8 & 9.3 & 7.7 & 7.4 & 7.9 & 8.5 & 9.3 \\
\hline Short term & 9.8 & 7.7 & 7.1 & 5.8 & 5.7 & 5.6 & 5.6 & 5.5 \\
\hline Corporate & 7.5 & 8.3 & 8.0 & 6.9 & 7.2 & 7.6 & 7.9 & 8.3 \\
\hline Long term & 5.6 & 6.4 & 6.3 & 5.5 & 5.7 & 6.0 & 6.3 & 6.6 \\
\hline \multirow[t]{2}{*}{ Short term } & 1.9 & 1.9 & 1.7 & 1.4 & 1.5 & 1.6 & 1.6 & 1.7 \\
\hline & \multicolumn{8}{|c|}{ (in percent of GDP) } \\
\hline Gross external debt & 126.8 & 126.9 & 160.8 & 171.3 & 174.9 & 169.8 & 164.0 & 157.5 \\
\hline Public & 5.3 & 10.9 & 29.0 & 51.0 & 55.1 & 50.9 & 45.9 & 39.1 \\
\hline Private & 121.5 & 115.9 & 131.8 & 120.3 & 119.8 & 118.9 & 118.1 & 118.4 \\
\hline Banks & 85.6 & 80.1 & 88.4 & 79.7 & 77.2 & 76.3 & 75.5 & 75.9 \\
\hline Long term & 38.8 & 46.8 & 50.1 & 45.6 & 43.6 & 44.6 & 45.6 & 47.6 \\
\hline Short term & 46.8 & 33.3 & 38.3 & 34.1 & 33.7 & 31.7 & 30.0 & 28.3 \\
\hline Corporate & 35.9 & 35.8 & 43.5 & 40.7 & 42.5 & 42.6 & 42.6 & 42.5 \\
\hline Long term & 26.6 & 27.8 & 34.1 & 32.1 & 33.7 & 33.8 & 33.9 & 33.9 \\
\hline Short term & 9.3 & 8.1 & 9.4 & 8.5 & 8.9 & 8.8 & 8.7 & 8.6 \\
\hline Change in debt to GDP & 12.0 & 0.1 & 34.0 & 10.5 & 3.6 & -5.1 & -5.8 & -6.5 \\
\hline Due to change in nominal debt & 40.0 & 11.5 & 2.3 & -3.9 & 3.4 & 2.8 & 2.4 & 1.7 \\
\hline Due to nominal GDP & -28.0 & -11.4 & 31.7 & 14.3 & 0.2 & -7.9 & -8.2 & -8.2 \\
\hline \multicolumn{9}{|l|}{ Memo items: - } \\
\hline GDP (billions euros) & 21.0 & 23.1 & 18.5 & 17.0 & 16.9 & 17.7 & 18.6 & 19.6 \\
\hline
\end{tabular}

Source: Latvian authorities and IMF staff estimates and projections. 
Table 8. Latvia: External Debt Sustainability Framework, 2004-2014

(In percent of GDP, unless otherwise indicated)

\begin{tabular}{|c|c|c|c|c|c|c|c|c|c|c|c|c|}
\hline & \multicolumn{5}{|c|}{ Actual } & \multicolumn{7}{|c|}{ Projections } \\
\hline & 2004 & 2005 & 2006 & 2007 & 2008 & 2009 & 2010 & 2011 & 2012 & 2013 & 2014 & Debt-stabilizing \\
\hline Baseline: External debt & 89.3 & 100.0 & 114.8 & 126.8 & 126.9 & 160.8 & 171.3 & 174.9 & 169.9 & 164.0 & 157.5 & $\begin{array}{c}\text { current account } 6 / \\
-9.5\end{array}$ \\
\hline Change in external debt & 12.8 & 10.7 & 14.8 & 12.0 & 0.1 & 34.0 & 10.5 & 3.6 & -5.0 & -5.9 & -6.5 & \\
\hline Identified external debt-creating flows $(4+8+9)$ & 1.0 & -3.1 & -2.3 & -11.5 & -1.8 & 20.9 & -3.1 & -11.0 & -16.1 & -15.9 & -15.6 & \\
\hline Current account deficit, excluding interest payments & 11.0 & 10.4 & 19.3 & 18.5 & 7.8 & -12.3 & -14.1 & -8.4 & -8.6 & -8.3 & -7.7 & \\
\hline Deficit in balance of goods and services & 15.9 & 15.2 & 22.3 & 20.6 & 13.0 & 1.4 & -3.2 & -3.6 & -4.0 & -4.2 & -4.0 & \\
\hline Exports & 43.6 & 47.0 & 44.0 & 41.3 & 41.5 & 36.6 & 41.0 & 44.4 & 45.8 & 46.7 & 47.7 & \\
\hline Imports & 59.5 & 62.2 & 66.2 & 61.9 & 54.4 & 38.0 & 37.9 & 40.9 & 41.9 & 42.5 & 43.6 & \\
\hline Net non-debt creating capital inflows (negative) & -3.8 & -3.1 & -5.9 & -6.0 & -3.0 & -3.2 & -3.6 & -3.4 & -4.7 & -5.0 & -5.2 & \\
\hline Automatic debt dynamics $1 /$ & -6.2 & -10.4 & -15.8 & -23.9 & -6.6 & 36.4 & 14.6 & 0.8 & -2.8 & -2.5 & -2.6 & \\
\hline Contribution from nominal interest rate & 1.9 & 2.2 & 3.1 & 4.1 & 4.9 & 7.8 & 7.7 & 3.4 & 3.7 & 3.7 & 3.6 & \\
\hline Contribution from real GDP growth & -5.9 & -8.1 & -9.9 & -8.7 & 5.3 & 28.6 & 7.0 & -2.5 & -6.4 & -6.3 & -6.3 & \\
\hline Contribution from price and exchange rate changes $2 /$ & -2.2 & -4.4 & -9.0 & -19.4 & -16.7 & & & & & & & \\
\hline Residual, incl. change in gross foreign assets $(2-3) 3 /$ & 11.8 & 13.8 & 17.1 & 23.5 & 1.9 & 13.1 & 13.5 & 14.6 & 11.1 & 10.1 & 9.0 & \\
\hline External debt-to-exports ratio (in percent) & 204.8 & 212.6 & 261.0 & 307.2 & 305.9 & 439.8 & 417.6 & 393.5 & 370.6 & 351.0 & 330.4 & \\
\hline Gross external financing need (in billions of euros) $4 /$ & 6.8 & 9.5 & 12.2 & 15.0 & 17.1 & 11.3 & 10.4 & 11.3 & 12.2 & 13.3 & 13.5 & \\
\hline in percent of GDP & 61.5 & 73.4 & 76.6 & 71.2 & 74.2 & 61.4 & 61.4 & 66.8 & 68.8 & 71.3 & 69.0 & \\
\hline Scenario with key variables at their historical averages 5 / & & & & & & 160.8 & 157.1 & 157.1 & 156.9 & 155.8 & 153.7 & -17.6 \\
\hline \multicolumn{13}{|l|}{ Key Macroeconomic Assumptions Underlying Baseline } \\
\hline Real GDP growth (in percent) & 8.7 & 10.6 & 12.2 & 10.0 & -4.6 & -18.0 & -4.0 & 1.5 & 3.8 & 3.9 & 4.0 & \\
\hline GDP deflator in euros (change in percent) & 3.0 & 5.2 & 9.9 & 20.3 & 15.2 & -2.4 & -4.4 & -1.6 & 0.8 & 1.1 & 1.2 & \\
\hline Nominal external interest rate (in percent) & 2.8 & 2.8 & 3.9 & 4.7 & 4.2 & 4.9 & 4.4 & 2.0 & 2.2 & 2.3 & 2.3 & \\
\hline Growth of exports (euro terms, in percent) & 16.7 & 25.5 & 15.3 & 24.1 & 8.0 & -29.6 & 1.3 & 8.3 & 8.6 & 8.0 & 8.0 & \\
\hline Growth of imports (euros, in percent) & 22.2 & 21.6 & 31.3 & 23.5 & -5.7 & -42.6 & -10.0 & 4.9 & 8.0 & 7.4 & 7.3 & \\
\hline Current account balance, excluding interest payments & -11.0 & -10.4 & -19.3 & -18.5 & -7.8 & 12.3 & 14.1 & 8.4 & 8.6 & 8.3 & 7.7 & \\
\hline Net non-debt creating capital inflows & 3.8 & 3.1 & 5.9 & 6.0 & 3.0 & 3.2 & 3.6 & 3.4 & 4.7 & 5.0 & 5.2 & \\
\hline
\end{tabular}

$1 /$ Derived as $[r-g-r(1+g)+$ ea $(1+r)](1+g+r+g r)$ times previous period debt stock, with $r=$ nominal effective interest rate on external debt; $r=$ change in domestic GDP deflator in US dollar terms, $g=$ real GDP growth rate, $e=$ nominal appreciation (in

$2 /$ The contribution from price and exchange rate changes is defined as $[-r(1+g)+e a(1+r)](1+g+r+g r)$ times previous period debt stock. $r$ increases with an appreciating domestic currency $(e>0)$ and rising inflation (based on GDP deflator).

3/ For projection, line includes the impact of price and exchange rate changes.

4/ Defined as current account deficit, plus amortization on medium- and long-term debt, plus short-term debt at end of previous period.

5/ The key variables include real GDP growth; nominal interest rate; dollar deflator growth; and both non-interest current account and non-debt inflows in percent of GDP.

6/ Long-run, constant balance that stabilizes the debt ratio assuming that key variables (real GDP growth, nominal interest rate, dollar deflator growth, and non-debt inflows in percent of GDP) remain at their levels of the last projection year. 
Table 9. Latvia: Selected Vulnerability Indicators, 2005-09

\begin{tabular}{|c|c|c|c|c|c|c|}
\hline & 2005 & 2006 & 2007 & 2008 & $20091 /$ & $\begin{array}{c}\text { Latest } \\
\text { Observation }\end{array}$ \\
\hline \multicolumn{7}{|l|}{ Key economic and market indicators } \\
\hline Real GDP growth (in percent) & 10.6 & 12.2 & 10.0 & -4.6 & -18.0 & Q1, 2009 \\
\hline HICP inflation (period average, in percent) & 6.9 & 6.6 & 10.1 & 15.3 & 3.1 & Jun-09 \\
\hline Short-term (ST) interbank rate, 1-month RIGIBOR (eop, in percent) & 4.4 & 2.9 & 6.8 & 13.3 & 30.9 & Jun-09 \\
\hline Eurobond secondary market spread (bps, eop) & 16 & 19 & 58 & 446 & 651 & Jun-09 \\
\hline Exchange rate NC/US\$ (eop) & 0.59 & 0.54 & 0.48 & 0.48 & 0.50 & Jun-09 \\
\hline Exchange rate NC/US\$ (period average) & 0.56 & 0.56 & 0.51 & 0.48 & 0.53 & Jun-09 \\
\hline \multicolumn{7}{|l|}{ External sector } \\
\hline Exchange rate regime & \multicolumn{6}{|c|}{ Pegged to the euro (+-1\% band) } \\
\hline Current account balance (in percent of GDP) & -12.5 & -22.5 & -22.5 & -12.6 & 1.1 & Q1, 2009 \\
\hline Net FDI inflows (in percent of GDP) & 3.6 & 7.5 & 6.7 & 3.3 & 2.4 & Q1, 2009 \\
\hline Exports (in percentage change of US\$ value, GNFS) & 25.4 & 16.7 & 34.8 & 18.9 & -31.7 & Apr-09 \\
\hline Real effective exchange rate index ( $2000=100$, period average) & 90.1 & 92.7 & 100.1 & 111.3 & 119.2 & May-09 \\
\hline Gross international reserves (GIR, in US\$ billion) & 2.4 & 4.5 & 5.8 & 5.2 & 3.8 & Jun-09 \\
\hline $\begin{array}{l}\text { GIR in percent of ST debt at remaining maturity (RM) excluding non- } \\
\text { resident deposits }\end{array}$ & 92.6 & 66.0 & 67.5 & 71.8 & 61.2 & Q2, 2009 \\
\hline GIR in percent of ST debt at RM including banks' non-resident FX deposits. & 31.5 & 35.9 & 33.9 & 38.0 & 32.6 & Q2, 2009 \\
\hline Net international reserves (NIR, in US\$ billion) & 2.3 & 4.4 & 5.7 & 4.7 & 3.8 & Jun-09 \\
\hline Total gross external debt (ED, in percent of GDP) & 100.0 & 114.8 & 126.8 & 126.9 & 128.0 & Q1, 2009 \\
\hline ST external debt (original maturity, in percent of total ED) & 49.3 & 44.1 & 44.3 & 32.6 & 28.4 & Q1, 2009 \\
\hline ED of domestic private sector (in percent of total ED) & 93.3 & 94.8 & 95.8 & 91.4 & 88.8 & Q1, 2009 \\
\hline Total gross external debt (in percent of exports of GNFS) & 212.6 & 261.0 & 307.2 & 305.9 & 386.4 & Q1, 2009 \\
\hline Gross external financing requirement (in US\$ billion) 2/ & 3.8 & 6.6 & 9.8 & 7.8 & 2.4 & Q2, 2009 \\
\hline \multicolumn{7}{|l|}{ Public sector (PS) 3/ } \\
\hline Basic balance (excluding bank restructuring costs; in percent of GDP) & -1.1 & -0.9 & 0.7 & -3.3 & -3.8 & Q2, 2009 \\
\hline Primary basic balance (in percent of GDP) & -0.5 & -0.3 & 1.0 & -2.9 & -3.1 & Q2, 2009 \\
\hline Debt-stabilizing primary balance (in percent of GDP) & $\ldots$ & -1.3 & -1.6 & -0.5 & $\ldots$ & \\
\hline Gross PS financing requirement (in percent of GDP) 4/ & 3.1 & 2.6 & 0.2 & 8.8 & 7.6 & Q2, 2009 \\
\hline General government gross debt (in percent of GDP) & 11.6 & 9.9 & 7.8 & 17.0 & 23.7 & Q2, 2009 \\
\hline \multicolumn{7}{|l|}{ Financial sector (FS) 5/ } \\
\hline Capital adequacy ratio (in percent) & 10.1 & 10.2 & 11.1 & 11.8 & 12.8 & May, 2009 \\
\hline Overdue loans (in percent of total loans) $6 /$ & $\ldots$ & 0.5 & 0.8 & 3.6 & 10.7 & May, 2009 \\
\hline Provisions (in percent of overdue loans) & $\ldots$ & 93.3 & 64.9 & 61.3 & 40.7 & May, 2009 \\
\hline Return on average assets (in percent) & 2.1 & 2.1 & 2.0 & 0.3 & -1.6 & May, 2009 \\
\hline Return on equity (in percent) & 27.1 & 25.6 & 24.2 & 4.6 & -19.7 & May, 2009 \\
\hline Residents' FX deposits (in percent of total resident deposits) & 39.9 & 40.3 & 46.8 & 47.1 & 59.0 & May, 2009 \\
\hline FX loans to residents (in percent of total loans to residents) & 70.0 & 76.9 & 86.4 & 88.2 & 89.4 & Q1, 2009 \\
\hline Credit to private sector (percent change, year-on-year) $7 /$ & 64.3 & 58.4 & 34.0 & 11.2 & 2.5 & May, 2009 \\
\hline \multicolumn{7}{|l|}{ Memorandum item: } \\
\hline Nominal GDP in billions of U.S. dollars & 16.0 & 19.9 & 28.8 & 34.0 & 6.1 & Q1 2009 \\
\hline
\end{tabular}

Sources: Latvian authorities, and Fund staff calculations.

1/ Latest observations as indicated in the last column.

2/ Current account deficit plus amortization of external debt.

3/ Public sector covers general government.

4/ Overall balance plus debt amortization.

5/ Financial sector includes commercial banks.

6/ 90-days overdue.

7/ Total loans less loans to the public sector and transit loans, provided to both residents and non-residents. 
Table 10. Latvia: General Government Operations: Baseline before the supplementary budget, 2008-10

\begin{tabular}{|c|c|c|c|}
\hline & 2008 & 2009 & 2010 \\
\hline & Prel. Est. & \multicolumn{2}{|c|}{ Baseline } \\
\hline & \multicolumn{3}{|c|}{ (In millions of lats) } \\
\hline Total revenue and grants & 5,722 & 4,558 & 3,890 \\
\hline Tax revenue & 4,737 & 3,353 & 2,880 \\
\hline Direct Taxes & 3,004 & 1,996 & 1,682 \\
\hline Corporate Income Tax & 503 & 185 & 77 \\
\hline Personal Income Tax & 1,029 & 705 & 615 \\
\hline Capital Income Tax & & 0 & 0 \\
\hline Social Security Contributions & 1,401 & 1,035 & 930 \\
\hline Real Estate and Property Taxes & 71 & 71 & 60 \\
\hline Indirect Taxes & 1,733 & 1,357 & 1,198 \\
\hline VAT & 1,117 & 790 & 690 \\
\hline Excises & 541 & 516 & 464 \\
\hline Other indirect taxes & 74 & 50 & 43 \\
\hline Non Tax, self-earnt and other revenue & 555 & 643 & 410 \\
\hline EU and miscellaneous funds & 430 & 562 & 600 \\
\hline Total expenditure 1/ & 6,255 & 6,634 & 6,738 \\
\hline Current expenditure & 5,517 & 6,010 & 6,134 \\
\hline Primary Current Expenditure & 5,453 & 5,777 & 5,637 \\
\hline Remuneration & & 1,469 & 1,469 \\
\hline Wages and Salaries & 1,267 & 1,127 & 1,127 \\
\hline Goods and Services & 922 & 744 & 719 \\
\hline Subsidies and Grants & 2,700 & 3,326 & 3,317 \\
\hline Subsidies to companies and institutions & 1,187 & 1,463 & 1,413 \\
\hline Social Support & 1,383 & 1,849 & 1,893 \\
\hline Pensions & 954 & 1,146 & 1,181 \\
\hline Other & 429 & 703 & 711 \\
\hline Other Subsidies and Grants & 130 & 14 & 12 \\
\hline Payments to EU budget & 154 & 153 & 119 \\
\hline Other current expenditure and net lending & 410 & 84 & 12 \\
\hline Interest & 64 & 233 & 498 \\
\hline Capital expenditure & 738 & 624 & 603 \\
\hline Basic fiscal balance $2 /$ & -533 & $-2,076$ & $-2,848$ \\
\hline Bank restructuring costs $1 /$ & 674 & 1,007 & 934 \\
\hline Fiscal balance & $-1,207$ & $-3,082$ & $-3,781$ \\
\hline Financing (net) & 1,207 & 3,082 & 3,781 \\
\hline Domestic financing & 495 & 642 & -527 \\
\hline External financing & 710 & 2,440 & 4,309 \\
\hline Financing gap & 0 & 0 & 0 \\
\hline
\end{tabular}


Table 10. Latvia: General Government Operations: Baseline before the supplementary budget, 2008-10 (concluded)

\begin{tabular}{|c|c|c|c|}
\hline & 2008 & 2009 & 2010 \\
\hline & Prel. Est. & \multicolumn{2}{|c|}{ Baseline } \\
\hline & \multicolumn{3}{|c|}{ (in percent of GDP) } \\
\hline Total revenue and grants & 35.2 & 35.1 & 32.6 \\
\hline Tax revenue & 29.2 & 25.8 & 24.2 \\
\hline Direct Taxes & 18.5 & 15.4 & 14.1 \\
\hline Corporate Income Tax & 3.1 & 1.4 & 0.6 \\
\hline Personal Income Tax & 6.3 & 5.4 & 5.2 \\
\hline Capital Income Tax & $\ldots$ & 0.0 & 0.0 \\
\hline Social Security Contributions & 8.6 & 8.0 & 7.8 \\
\hline Real Estate and Property Taxes & 0.4 & 0.5 & 0.5 \\
\hline Indirect Taxes & 10.7 & 10.5 & 10.1 \\
\hline VAT & 6.9 & 6.1 & 5.8 \\
\hline Excises & 3.3 & 4.0 & 3.9 \\
\hline Other indirect taxes & 0.5 & 0.4 & 0.4 \\
\hline Non Tax, self-earnt and other revenue & 3.4 & 4.9 & 3.4 \\
\hline EU and miscellaneous funds & 2.6 & 4.3 & 5.0 \\
\hline Total expenditure $1 /$ & 38.5 & 51.1 & 56.5 \\
\hline Current expenditure & 34.0 & 46.3 & 51.5 \\
\hline Primary Current Expenditure & 33.6 & 44.5 & 47.3 \\
\hline Remuneration & & 11.3 & 12.3 \\
\hline Wages and Salaries & 7.8 & 8.7 & 9.5 \\
\hline Goods and Services & 5.7 & 5.7 & 6.0 \\
\hline Subsidies and Grants & 16.6 & 25.6 & 27.8 \\
\hline Subsidies to companies and institutions & 7.3 & 11.3 & 11.9 \\
\hline Social Support & 8.5 & 14.2 & 15.9 \\
\hline Pensions & 5.9 & 8.8 & 9.9 \\
\hline Other & 2.6 & 5.4 & 6.0 \\
\hline Other Subsidies and Grants & 0.8 & 0.1 & 0.1 \\
\hline Payments to EU budget & 0.9 & 1.2 & 1.0 \\
\hline Other current expenditure and net lending & 2.5 & 0.6 & 0.1 \\
\hline Interest & 0.4 & 1.8 & 4.2 \\
\hline Capital expenditure & 4.5 & 4.8 & 5.1 \\
\hline Basic fiscal balance $2 /$ & -3.3 & -16.0 & -23.9 \\
\hline Bank restructuring costs $1 /$ & 4.1 & 7.8 & 7.8 \\
\hline Fiscal balance & -7.4 & -23.7 & -31.7 \\
\hline Financing (net) & 7.4 & 23.7 & 31.7 \\
\hline Domestic financing & 3.0 & 4.9 & -4.4 \\
\hline External financing & 4.4 & 18.8 & 36.2 \\
\hline Financing gap & 0.0 & 0.0 & 0.0 \\
\hline \multicolumn{4}{|l|}{ Memorandum items } \\
\hline Nominal GDP (In millions of lats) & 16,243 & 12,981 & 11,918 \\
\hline Real GDP growth & -4.6 & -18.0 & -4.0 \\
\hline General government gross debt & 17.0 & 49.6 & 90.5 \\
\hline Domestic Currency & 6.5 & 13.9 & 18.2 \\
\hline Foreign Currency & 10.5 & 35.7 & 72.4 \\
\hline General government contingent liabilities & 29.1 & 36.3 & 39.2 \\
\hline
\end{tabular}

Sources: Latvian Authorities, and IMF staff estimates.

1/ Total expenditure exclude Net acquisition of financial assets and other Bank restructuring costs impacting the fiscal balance.

2/ Basic fiscal balance, in cash, or Net government borrowing/lending. 
Table 11. Latvia: Impact of the Supplementary Budget and Additional Amendments on the General Government's basic fiscal balance, 2009-10

(Program Scenario; in percent of GDP, in cash)

\begin{tabular}{lcc}
\hline & 2009 & $\mathbf{2 0 1 0}$ \\
\hline Baseline fiscal balance 1/ & -16.0 & -23.9 \\
Impact of the supplementary budget & +3.5 & +6.5 \\
Recurrent measures & +1.1 & +1.9 \\
$\quad$ Decrease in personal income tax allowance & +0.3 & +0.8 \\
Pension cuts & +0.7 & +0.9 \\
Cuts in social subsidies & +0.1 & +0.2 \\
One-off measures & +0.6 & -0.3 \\
Expenditure cuts & +3.3 & +5.6 \\
$\quad$ Structural reforms in health and education & +0.7 & +1.3 \\
Across the board cuts in health and education & +0.7 & +0.9 \\
Other incompletely specified or across-the-board cuts & +1.9 & +3.3 \\
Expansionary measures 2/ & -1.5 & -0.7 \\
Expansion of social safety nets & -1.0 & -1.0 \\
Offsetting measure: reallocation of net lending & +0.5 & $\ldots$ \\
Baseline fiscal balance after the supplementary budget 1/ & -13.0 & -18.4 \\
2010 measures & $\ldots$ & +6.4 \\
Expansion of PIT base (except capital income) and progressive rate & $\ldots$ & +1.4 \\
Capital income tax & $\ldots$ & +0.1 \\
Real estate tax & $\ldots$ & +0.5 \\
VAT & $\ldots$ & +0.4 \\
Civil service reform & $\ldots$ & +0.6 \\
Fiscal balance 1/ & $\ldots$ & +3.4 \\
\hline
\end{tabular}

Sources: Latvian Authorities, and IMF staff estimates.

1/ Basic fiscal balance, or general government net borrowing requirement excluding bank restructuring costs. 2/ Includes net lending, recapitalization of state-owned enterprises, impact of commitments (+3.1 percent of GDP in 2010), and called guarantees. 
Table 12. Latvia: General Government Operations: Rapid Adjustment Scenario, 2008-14

\begin{tabular}{|c|c|c|c|c|c|c|c|}
\hline & 2008 & 2009 & 2010 & 2011 & 2012 & 2013 & 2014 \\
\hline & Prel. Est. & \multicolumn{6}{|c|}{ Proj. } \\
\hline & \multicolumn{7}{|c|}{ (In millions of lats) } \\
\hline Total revenue and grants & 5,722 & 4,589 & 4,244 & 4,237 & 4,448 & 4,823 & 5,069 \\
\hline Tax revenue & 4,737 & 3,352 & 3,211 & 3,229 & 3,423 & 3,773 & 3,913 \\
\hline Direct Taxes & 3,004 & 1,991 & 1,945 & 1,921 & 2,021 & 2,304 & 2,379 \\
\hline Corporate Income Tax & 503 & 185 & 82 & 76 & 76 & 305 & 320 \\
\hline Personal Income Tax & 1,029 & 721 & 846 & 823 & 899 & 925 & 950 \\
\hline Capital Income Tax & & 0 & 12 & 31 & 32 & 34 & 36 \\
\hline Social Security Contributions & 1,401 & 1,015 & 885 & 871 & 888 & 908 & 935 \\
\hline Real Estate and Property Taxes & 71 & 71 & 120 & 120 & 125 & 132 & 138 \\
\hline Indirect Taxes & 1,733 & 1,361 & 1,266 & 1,307 & 1,402 & 1,469 & 1,534 \\
\hline VAT & 1,117 & 790 & 743 & 793 & 869 & 912 & 949 \\
\hline Excises & 541 & 520 & 475 & 467 & 482 & 502 & 523 \\
\hline Other indirect taxes & 74 & 50 & 48 & 48 & 51 & 56 & 62 \\
\hline Non Tax, self-earnt and other revenue & 555 & 674 & 433 & 408 & 425 & 450 & 544 \\
\hline EU and miscellaneous funds & 430 & 562 & 600 & 600 & 600 & 600 & 612 \\
\hline Total expenditure $1 /$ & 6,255 & 6,279 & 5,256 & 4,949 & 4,821 & 4,996 & 5,138 \\
\hline Current expenditure & 5,517 & 5,734 & 5,543 & 5,528 & 5,651 & 5,818 & 6,007 \\
\hline Primary Current Expenditure & 5,453 & 5,512 & 5,159 & 4,994 & 5,006 & 5,080 & 5,188 \\
\hline Remuneration & $\ldots$ & 1,350 & 1,178 & 1,178 & 1,178 & 1,201 & 1,264 \\
\hline Wages and Salaries & 1,267 & 1,036 & 904 & 904 & 904 & 922 & 970 \\
\hline Goods and Services & 922 & 696 & 671 & 657 & 659 & 665 & 672 \\
\hline Subsidies and Grants & 2,700 & 3,097 & 3,090 & 2,941 & 2,940 & 2,973 & 2,998 \\
\hline Subsidies to companies and institutions & 1,187 & 1,208 & 1,208 & 1,175 & 1,183 & 1,192 & 1,204 \\
\hline Social Support & 1,383 & 1,875 & 1,870 & 1,753 & 1,743 & 1,767 & 1,780 \\
\hline Pensions & 954 & 1,055 & 1,073 & 1,073 & 1,073 & 1,095 & 1,130 \\
\hline Other & 429 & 820 & 797 & 680 & 670 & 672 & 650 \\
\hline Other Subsidies and Grants & 130 & 14 & 12 & 12 & 13 & 14 & 14 \\
\hline Payments to EU budget & 154 & 153 & 119 & 119 & 125 & 131 & 138 \\
\hline Other current expenditure and net lending & 410 & 216 & 100 & 100 & 105 & 110 & 116 \\
\hline Interest & 64 & 222 & 384 & 533 & 645 & 738 & 820 \\
\hline Capital expenditure & 738 & 544 & 550 & 550 & 545 & 623 & 652 \\
\hline Measures to be identified & $\ldots$ & 0 & -837 & $-1,128$ & $-1,376$ & $-1,446$ & $-1,521$ \\
\hline Basic fiscal balance 2/ & -533 & $-1,690$ & $-1,012$ & -712 & -373 & -173 & -69 \\
\hline Bank restructuring costs $1 /$ & 674 & 1,007 & 934 & 855 & 0 & 0 & 0 \\
\hline Fiscal balance & $-1,207$ & $-2,697$ & $-1,946$ & $-1,566$ & -373 & -173 & -69 \\
\hline
\end{tabular}


Table 12. Latvia: General Government Operations: Rapid Adjustment Scenario, 2008-14 (concluded)

\begin{tabular}{|c|c|c|c|c|c|c|c|}
\hline & 2008 & 2009 & 2010 & 2011 & 2012 & 2013 & 2014 \\
\hline & Prel. Est. & \multicolumn{6}{|c|}{ Proj. } \\
\hline & \multicolumn{7}{|c|}{ (in percent of GDP) } \\
\hline Total revenue and grants & 35.2 & 35.3 & 35.6 & 35.6 & 35.7 & 36.8 & 36.8 \\
\hline Tax revenue & 29.2 & 25.8 & 26.9 & 27.1 & 27.5 & 28.8 & 28.4 \\
\hline Direct Taxes & 18.5 & 15.3 & 16.3 & 16.1 & 16.2 & 17.6 & 17.3 \\
\hline Corporate Income Tax & 3.1 & 1.4 & 0.7 & 0.6 & 0.6 & 2.3 & 2.3 \\
\hline Personal Income Tax & 6.3 & 5.6 & 7.1 & 6.9 & 7.2 & 7.1 & 6.9 \\
\hline Capital Income Tax & $\ldots$ & 0.0 & 0.1 & 0.3 & 0.3 & 0.3 & 0.3 \\
\hline Social Security Contributions & 8.6 & 7.8 & 7.4 & 7.3 & 7.1 & 6.9 & 6.8 \\
\hline Real Estate and Property Taxes & 0.4 & 0.5 & 1.0 & 1.0 & 1.0 & 1.0 & 1.0 \\
\hline Indirect Taxes & 10.7 & 10.5 & 10.6 & 11.0 & 11.2 & 11.2 & 11.1 \\
\hline VAT & 6.9 & 6.1 & 6.2 & 6.7 & 7.0 & 7.0 & 6.9 \\
\hline Excises & 3.3 & 4.0 & 4.0 & 3.9 & 3.9 & 3.8 & 3.8 \\
\hline Other indirect taxes & 0.5 & 0.4 & 0.4 & 0.4 & 0.4 & 0.4 & 0.4 \\
\hline Non Tax, self-earnt and other revenue & 3.4 & 5.2 & 3.6 & 3.4 & 3.4 & 3.4 & 3.9 \\
\hline EU and miscellaneous funds & 2.6 & 4.3 & 5.0 & 5.0 & 4.8 & 4.6 & 4.4 \\
\hline Total expenditure $1 /$ & 38.5 & 48.4 & 44.1 & 41.6 & 38.7 & 38.2 & 37.3 \\
\hline Current expenditure & 34.0 & 44.2 & 46.5 & 46.4 & 45.3 & 44.4 & 43.6 \\
\hline Primary Current Expenditure & 33.6 & 42.5 & 43.3 & 42.0 & 40.2 & 38.8 & 37.7 \\
\hline Remuneration & $\ldots$ & 10.4 & 9.9 & 9.9 & 9.5 & 9.2 & 9.2 \\
\hline Wages and Salaries & 7.8 & 8.0 & 7.6 & 7.6 & 7.3 & 7.0 & 7.0 \\
\hline Goods and Services & 5.7 & 5.4 & 5.6 & 5.5 & 5.3 & 5.1 & 4.9 \\
\hline Subsidies and Grants & 16.6 & 23.9 & 25.9 & 24.7 & 23.6 & 22.7 & 21.8 \\
\hline Subsidies to companies and institutions & 7.3 & 9.3 & 10.1 & 9.9 & 9.5 & 9.1 & 8.7 \\
\hline Social Support & 8.5 & 14.4 & 15.7 & 14.7 & 14.0 & 13.5 & 12.9 \\
\hline Pensions & 5.9 & 8.1 & 9.0 & 9.0 & 8.6 & 8.4 & 8.2 \\
\hline Other & 2.6 & 6.3 & 6.7 & 5.7 & 5.4 & 5.1 & 4.7 \\
\hline Other Subsidies and Grants & 0.8 & 0.1 & 0.1 & 0.1 & 0.1 & 0.1 & 0.1 \\
\hline Payments to EU budget & 0.9 & 1.2 & 1.0 & 1.0 & 1.0 & 1.0 & 1.0 \\
\hline Other current expenditure and net lending & 2.5 & 1.7 & 0.8 & 0.8 & 0.8 & 0.8 & 0.8 \\
\hline Interest & 0.4 & 1.7 & 3.2 & 4.5 & 5.2 & 5.6 & 5.9 \\
\hline Capital expenditure & 4.5 & 4.2 & 4.6 & 4.6 & 4.4 & 4.8 & 4.7 \\
\hline Measures to be identified & $\ldots$ & 0.0 & -7.0 & -9.5 & -11.0 & -11.0 & -11.0 \\
\hline Basic fiscal balance $2 /$ & -3.3 & -13.0 & -8.5 & -6.0 & -3.0 & -1.3 & -0.5 \\
\hline Bank restructuring costs $1 /$ & 4.1 & 7.8 & 7.8 & 7.2 & 0.0 & 0.0 & 0.0 \\
\hline Fiscal balance & -7.4 & -20.8 & -16.3 & -13.2 & -3.0 & -1.3 & -0.5 \\
\hline Financing (net) & 7.4 & 20.8 & 16.3 & 13.2 & 3.0 & 1.3 & 0.5 \\
\hline Domestic financing & 3.0 & 1.1 & 0.4 & 12.6 & 9.4 & 7.7 & 7.7 \\
\hline External financing & 4.4 & 19.7 & 15.9 & 0.5 & -6.4 & -6.4 & -7.2 \\
\hline Financing gap & 0.0 & 0.0 & 0.0 & 0.0 & 0.0 & 0.0 & 0.0 \\
\hline \multicolumn{8}{|l|}{ Memorandum items } \\
\hline Nominal GDP (In millions of lats) & 16,243 & 12,981 & 11,918 & 11,903 & 12,462 & 13,091 & 13,777 \\
\hline Real GDP growth & -4.6 & -18.0 & -4.0 & 1.5 & 3.8 & 3.9 & 4.0 \\
\hline Additional social safety nets & $\ldots$ & 1.0 & 1.0 & 0.5 & $\ldots$ & $\ldots$ & $\ldots$ \\
\hline Primary balance & -7.0 & -19.1 & -13.1 & -8.7 & 2.2 & 4.3 & 5.5 \\
\hline General government gross debt & 17.0 & 43.5 & 70.7 & 80.2 & 78.0 & 75.6 & 72.5 \\
\hline General government contingent liabilities & 29.1 & 36.3 & 39.2 & $\ldots$ & $\ldots$ & $\ldots$ & $\ldots$ \\
\hline
\end{tabular}

Sources: Latvian Authorities, and IMF staff estimates.

1/ Total expenditure exclude Net acquisition of financial assets and other Bank restructuring costs impacting the fiscal balance. 2/ Basic fiscal balance, in cash, or Net government borrowing/lending. 
Table 13. Latvia: Public Sector Debt Sustainability Framework, Rapid Adjustment Scenario, 2004-2014 (In percent of GDP, unless otherwise indicated)



$1 /$ Indicate coverage of public sector, e.g., general government or nonfinancial public sector. Also whether net or gross debt is used.

$2 /$ Derived as $[(r-\pi(1+g)-g+\alpha(1+r)](1+g+\pi+g \pi))$ times previous period debt ratio, with $r=$ interest rate; $\pi=$ growth rate of GDP deflator; $g=$ real GDP growth rate; $\alpha=$ share of foreign-currency denominated debt; and $\varepsilon=$ nominal exchange rate depreciation (measured by increase in local currency value of U.S. dollar).

$3 /$ The real interest rate contribution is derived from the denominator in footnote $2 /$ as $r-\pi(1+g)$ and the real growth contribution as $-g$.

$4 /$ The exchange rate contribution is derived from the numerator in footnote $2 /$ as $\alpha \varepsilon(1+r)$.

5 / For projections, this line includes exchange rate changes.

$6 /$ Defined as public sector deficit, plus amortization of medium and long-term public sector debt, plus short-term debt at end of previous period.

7/ The key variables include real GDP growth; real interest rate; and primary balance in percent of GDP.

$8 /$ Derived as nominal interest expenditure divided by previous period debt stock.

9/Assumes that key variables (real GDP growth, real interest rate, and other identified debt-creating flows) remain at the level of the last projection year. 
Table 14. Latvia: General Government Operations: Program Scenario, 2008-14

\begin{tabular}{|c|c|c|c|c|c|c|c|}
\hline & 2008 & 2009 & 2010 & 2011 & 2012 & 2013 & 2014 \\
\hline & Prel. Est. & \multicolumn{6}{|c|}{ Proj. } \\
\hline & \multicolumn{7}{|c|}{ (In millions of lats) } \\
\hline Total revenue and grants & 5,722 & 4,589 & 4,244 & 4,237 & 4,448 & 4,823 & 5,069 \\
\hline Tax revenue & 4,737 & 3,352 & 3,211 & 3,229 & 3,423 & 3,773 & 3,913 \\
\hline Direct Taxes & 3,004 & 1,991 & 1,945 & 1,921 & 2,021 & 2,304 & 2,379 \\
\hline Corporate Income Tax & 503 & 185 & 82 & 76 & 76 & 305 & 320 \\
\hline Personal Income Tax & 1,029 & 721 & 846 & 823 & 899 & 925 & 950 \\
\hline Capital Income Tax & $\ldots$ & 0 & 12 & 31 & 32 & 34 & 36 \\
\hline Social Security Contributions & 1,401 & 1,015 & 885 & 871 & 888 & 908 & 935 \\
\hline Real Estate and Property Taxes & 71 & 71 & 120 & 120 & 125 & 132 & 138 \\
\hline Indirect Taxes & 1,733 & 1,361 & 1,266 & 1,307 & 1,402 & 1,469 & 1,534 \\
\hline VAT & 1,117 & 790 & 743 & 793 & 869 & 912 & 949 \\
\hline Excises & 541 & 520 & 475 & 467 & 482 & 502 & 523 \\
\hline Other indirect taxes & 74 & 50 & 48 & 48 & 51 & 56 & 62 \\
\hline Non Tax, self-earnt and other revenue & 555 & 674 & 433 & 408 & 425 & 450 & 544 \\
\hline EU and miscellaneous funds & 430 & 562 & 600 & 600 & 600 & 600 & 612 \\
\hline Total expenditure $1 /$ & 6,255 & 6,279 & 5,673 & 5,368 & 5,383 & 5,478 & 5,483 \\
\hline Current expenditure & 5,517 & 5,734 & 5,558 & 5,580 & 5,753 & 5,977 & 6,214 \\
\hline Primary Current Expenditure & 5,453 & 5,512 & 5,159 & 4,994 & 5,006 & 5,080 & 5,188 \\
\hline Remuneration & $\ldots$ & 1,350 & 1,178 & 1,178 & 1,178 & 1,201 & 1,264 \\
\hline Wages and Salaries & 1,267 & 1,036 & 904 & 904 & 904 & 922 & 970 \\
\hline Goods and Services & 922 & 696 & 671 & 657 & 659 & 665 & 672 \\
\hline Subsidies and Grants & 2,700 & 3,097 & 3,090 & 2,941 & 2,940 & 2,973 & 2,998 \\
\hline Subsidies to companies and institutions & 1,187 & 1,208 & 1,208 & 1,175 & 1,183 & 1,192 & 1,204 \\
\hline Social Support & 1,383 & 1,875 & 1,870 & 1,753 & 1,743 & 1,767 & 1,780 \\
\hline Pensions & 954 & 1,055 & 1,073 & 1,073 & 1,073 & 1,095 & 1,130 \\
\hline Other & 429 & 820 & 797 & 680 & 670 & 672 & 650 \\
\hline Other Subsidies and Grants & 130 & 14 & 12 & 12 & 13 & 14 & 14 \\
\hline Payments to EU budget & 154 & 153 & 119 & 119 & 125 & 131 & 138 \\
\hline Other current expenditure and net lending & 410 & 216 & 100 & 100 & 105 & 110 & 116 \\
\hline Interest & 64 & 222 & 399 & 585 & 747 & 897 & 1,026 \\
\hline Capital expenditure & 738 & 544 & 550 & 550 & 545 & 623 & 652 \\
\hline Measures to be identified & $\ldots$ & 0 & -435 & -761 & -916 & $-1,122$ & $-1,383$ \\
\hline Basic fiscal balance $2 /$ & -533 & $-1,690$ & $-1,430$ & $-1,131$ & -935 & -655 & -414 \\
\hline Bank restructuring costs $1 /$ & 674 & 1,007 & 934 & 855 & 0 & 0 & 0 \\
\hline Fiscal balance & $-1,207$ & $-2,697$ & $-2,363$ & $-1,986$ & -935 & -655 & -414 \\
\hline Financing (net) & 1,207 & 2,697 & 2,363 & 1,986 & 935 & 655 & 414 \\
\hline Domestic financing & 495 & 144 & 54 & 1,505 & 1,148 & 985 & 1,032 \\
\hline External financing & 710 & 2,553 & 2,309 & 481 & -213 & -330 & -618 \\
\hline Financing gap & 0 & 0 & 0 & 0 & 0 & 0 & 0 \\
\hline
\end{tabular}


Table 14. Latvia: General Government Operations: Program Scenario, 2008-14 (concluded)

\begin{tabular}{|c|c|c|c|c|c|c|c|}
\hline & 2008 & 2009 & 2010 & 2011 & 2012 & 2013 & 2014 \\
\hline & Prel. Est. & \multicolumn{6}{|c|}{ Proj. } \\
\hline & \multicolumn{7}{|c|}{ (in percent of GDP) } \\
\hline Total revenue and grants & 35.2 & 35.3 & 35.6 & 35.6 & 35.7 & 36.8 & 36.8 \\
\hline Tax revenue & 29.2 & 25.8 & 26.9 & 27.1 & 27.5 & 28.8 & 28.4 \\
\hline Direct Taxes & 18.5 & 15.3 & 16.3 & 16.1 & 16.2 & 17.6 & 17.3 \\
\hline Corporate Income Tax & 3.1 & 1.4 & 0.7 & 0.6 & 0.6 & 2.3 & 2.3 \\
\hline Personal Income Tax & 6.3 & 5.6 & 7.1 & 6.9 & 7.2 & 7.1 & 6.9 \\
\hline Capital Income Tax & $\ldots$ & 0.0 & 0.1 & 0.3 & 0.3 & 0.3 & 0.3 \\
\hline Social Security Contributions & 8.6 & 7.8 & 7.4 & 7.3 & 7.1 & 6.9 & 6.8 \\
\hline Real Estate and Property Taxes & 0.4 & 0.5 & 1.0 & 1.0 & 1.0 & 1.0 & 1.0 \\
\hline Indirect Taxes & 10.7 & 10.5 & 10.6 & 11.0 & 11.2 & 11.2 & 11.1 \\
\hline VAT & 6.9 & 6.1 & 6.2 & 6.7 & 7.0 & 7.0 & 6.9 \\
\hline Excises & 3.3 & 4.0 & 4.0 & 3.9 & 3.9 & 3.8 & 3.8 \\
\hline Other indirect taxes & 0.5 & 0.4 & 0.4 & 0.4 & 0.4 & 0.4 & 0.4 \\
\hline Non Tax, self-earnt and other revenue & 3.4 & 5.2 & 3.6 & 3.4 & 3.4 & 3.4 & 3.9 \\
\hline EU and miscellaneous funds & 2.6 & 4.3 & 5.0 & 5.0 & 4.8 & 4.6 & 4.4 \\
\hline Total expenditure $1 /$ & 38.5 & 48.4 & 47.6 & 45.1 & 43.2 & 41.8 & 39.8 \\
\hline Current expenditure & 34.0 & 44.2 & 46.6 & 46.9 & 46.2 & 45.7 & 45.1 \\
\hline Primary Current Expenditure & 33.6 & 42.5 & 43.3 & 42.0 & 40.2 & 38.8 & 37.7 \\
\hline Remuneration & $\ldots$ & 10.4 & 9.9 & 9.9 & 9.5 & 9.2 & 9.2 \\
\hline Wages and Salaries & 7.8 & 8.0 & 7.6 & 7.6 & 7.3 & 7.0 & 7.0 \\
\hline Goods and Services & 5.7 & 5.4 & 5.6 & 5.5 & 5.3 & 5.1 & 4.9 \\
\hline Subsidies and Grants & 16.6 & 23.9 & 25.9 & 24.7 & 23.6 & 22.7 & 21.8 \\
\hline Subsidies to companies and institutions & 7.3 & 9.3 & 10.1 & 9.9 & 9.5 & 9.1 & 8.7 \\
\hline Social Support & 8.5 & 14.4 & 15.7 & 14.7 & 14.0 & 13.5 & 12.9 \\
\hline Pensions & 5.9 & 8.1 & 9.0 & 9.0 & 8.6 & 8.4 & 8.2 \\
\hline Other & 2.6 & 6.3 & 6.7 & 5.7 & 5.4 & 5.1 & 4.7 \\
\hline Other Subsidies and Grants & 0.8 & 0.1 & 0.1 & 0.1 & 0.1 & 0.1 & 0.1 \\
\hline Payments to EU budget & 0.9 & 1.2 & 1.0 & 1.0 & 1.0 & 1.0 & 1.0 \\
\hline Other current expenditure and net lending & 2.5 & 1.7 & 0.8 & 0.8 & 0.8 & 0.8 & 0.8 \\
\hline Interest & 0.4 & 1.7 & 3.4 & 4.9 & 6.0 & 6.9 & 7.5 \\
\hline Capital expenditure & 4.5 & 4.2 & 4.6 & 4.6 & 4.4 & 4.8 & 4.7 \\
\hline Measures to be identified & $\ldots$ & 0.0 & -3.7 & -6.4 & -7.3 & -8.6 & -10.0 \\
\hline Basic fiscal balance $2 /$ & -3.3 & -13.0 & -12.0 & -9.5 & -7.5 & -5.0 & -3.0 \\
\hline Bank restructuring costs $1 /$ & 4.1 & 7.8 & 7.8 & 7.2 & 0.0 & 0.0 & 0.0 \\
\hline Fiscal balance & -7.4 & -20.8 & -19.8 & -16.7 & -7.5 & -5.0 & -3.0 \\
\hline Financing (net) & 7.4 & 20.8 & 19.8 & 16.7 & 7.5 & 5.0 & 3.0 \\
\hline Domestic financing & 3.0 & 1.1 & 0.5 & 12.6 & 9.2 & 7.5 & 7.5 \\
\hline External financing & 4.4 & 19.7 & 19.4 & 4.0 & -1.7 & -2.5 & -4.5 \\
\hline Financing gap & 0.0 & 0.0 & 0.0 & 0.0 & 0.0 & 0.0 & 0.0 \\
\hline \multicolumn{8}{|l|}{ Memorandum items } \\
\hline Nominal GDP (In millions of lats) & 16,243 & 12,981 & 11,918 & 11,903 & 12,462 & 13,091 & 13,777 \\
\hline Real GDP growth & -4.6 & -18.0 & -4.0 & 1.5 & 3.8 & 3.9 & 4.0 \\
\hline Additional social safety nets & $\ldots$ & 1.0 & 1.0 & 0.5 & $\ldots$ & $\ldots$ & $\ldots$ \\
\hline Primary balance & -7.0 & -19.1 & -16.5 & -11.8 & -1.5 & 1.9 & 4.4 \\
\hline General government gross debt & 17.0 & 43.5 & 74.2 & 87.2 & 89.2 & 90.0 & 88.6 \\
\hline Domestic Currency & 6.5 & 10.7 & 19.1 & 28.0 & 34.4 & 40.3 & 45.9 \\
\hline Foreign Currency & 10.5 & 32.8 & 55.1 & 59.2 & 54.8 & 49.7 & 42.7 \\
\hline General government contingent liabilities & 29.1 & 36.3 & 39.2 & $\ldots$ & $\ldots$ & $\ldots$ & $\ldots$ \\
\hline
\end{tabular}

Sources: Latvian Authorities, and IMF staff estimates.

1/ Total expenditure exclude Net acquisition of financial assets and other Bank restructuring costs impacting the fiscal balance.

2/ Basic fiscal balance, in cash, or Net government borrowing/lending. 
Table 15. Latvia: Public Sector Debt Sustainability Framework, Program Scenario, 2004-2014 (In percent of GDP, unless otherwise indicated)

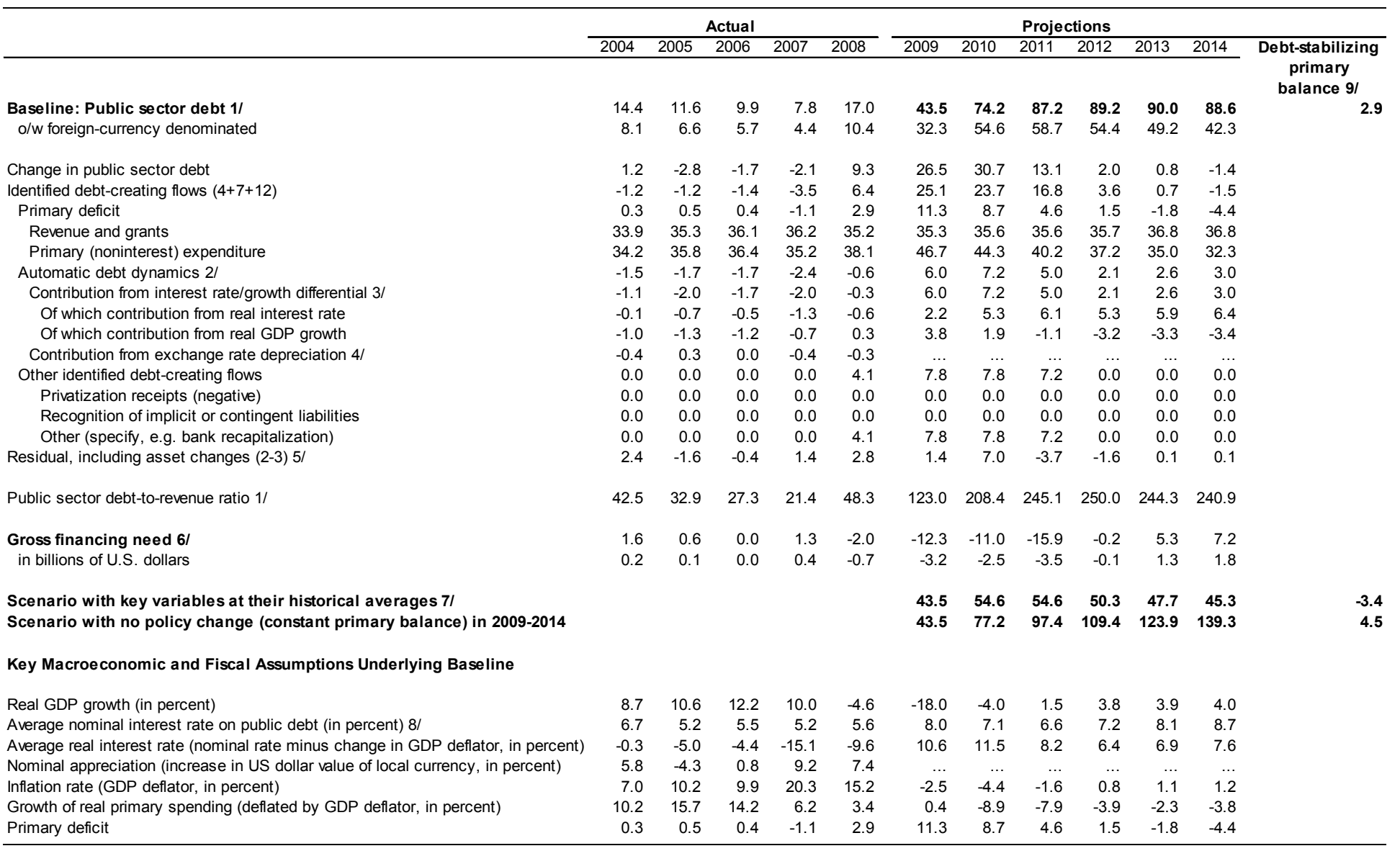

$1 /$ Indicate coverage of public sector, e.g., general government or nonfinancial public sector. Aso whether net or gross debt is used.

$2 /$ Derived as $\left[\left(r-\pi(1+g)-g+\alpha_{\delta}(1+r)\right] /(1+g+\pi+g \pi)\right)$ times previous period debt ratio, with $r=$ interest rate; $\pi$ = growth rate of GDP deflator; $g=$ real GDP growth rate; $\alpha=$ share of foreign-currency denominated debt; and $\varepsilon=$ nominal exchange rate depreciation (measured by increase in local currency value of U.S. dollar).

$3 /$ The real interest rate contribution is derived from the denominator in footnote $2 /$ as $r-\pi(1+g)$ and the real growth contribution as $-g$

$4 /$ The exchange rate contribution is derived from the numerator in footnote $2 /$ as $\alpha$ s $(1+r)$

$6 /$ Defined as public sector deficit, plus amortization of medium and long-term public sector debt, plus short-term debt at end of previous period.

7/ The key variables include real GDP growth; real interest rate; and primary balance in percent of GDP.

$8 /$ Derived as nominal interest expenditure divided by previous period debt stock.

9/ Assumes that key variables (real GDP growth, real interest rate, and other identified debt-creating flows) remain at the level of the last projection year. 
Table 16. Latvia: Schedule of Reviews and Purchases

\begin{tabular}{lccl}
\hline & \multicolumn{2}{c}{ Amount of purchase } & \\
\cline { 2 - 3 } Date & Millions of SDRs & Percent of quota & Conditions \\
\hline December 23, 2008 & 535.344 & 422.2 & Approval of arrangement \\
August 28, 2009 & 178.448 & 140.7 & First review, end-March 2009 performance criteria \\
November 15, 2009 & 178.448 & 140.7 & Second review and end-September 2009 performance criteria \\
February 15, 2010 & 178.448 & 140.7 & Third review and end-December 2009 performance criteria \\
May 15, 2010 & 178.448 & 140.7 & Fourth review and end-March 2010 performance criteria \\
August 15, 2010 & 89.224 & 70.4 & Fifth review and end-June 2010 performance criteria \\
November 15, 2010 & 89.224 & 70.4 & Sixth review and end-September 2010 performance criteria \\
February 15, 2011 & 94.042 & 74.2 & Seventh review and end-December 2010 performance criteria \\
Total & 1521.626 & 1200.0 & \\
\hline
\end{tabular}

Source: IMF staff estimates. 
Table 17. Latvia: Program Financing, 2008-11

(In millions of euros)

\begin{tabular}{|c|c|c|c|c|c|c|c|}
\hline & \multicolumn{3}{|c|}{2009} & \multirow{3}{*}{$\begin{array}{l}2009 \\
\text { Proj. }\end{array}$} & \multirow{3}{*}{$\begin{array}{l}2010 \\
\text { Proj. }\end{array}$} & \multirow{3}{*}{$\begin{array}{l}2011 \\
\text { Mar. } \\
\text { Proj. } \\
\end{array}$} & \multirow{3}{*}{$\begin{array}{c}2008-11 \\
\text { Total } \\
\text { Proj. } \\
\end{array}$} \\
\hline & Jun. & Sep. & Dec. & & & & \\
\hline & \multicolumn{3}{|c|}{ Projection } & & & & \\
\hline Total financing requirements & $-1,517$ & $-2,147$ & $-1,348$ & $-6,416$ & $-7,173$ & $-1,656$ & $-15,451$ \\
\hline $\begin{array}{l}\text { Medium and long term debt amortization } 1 / \\
\text { Public sector }\end{array}$ & -466 & $\begin{array}{r}-591 \\
-7\end{array}$ & $\begin{array}{r}-619 \\
-7\end{array}$ & $-2,241$ & $\begin{array}{r}-3,697 \\
-25\end{array}$ & $-1,343$ & $\begin{array}{r}-7,977 \\
-240\end{array}$ \\
\hline MFIs & -236 & -362 & -390 & $-1,322$ & $-2,769$ & -855 & $-5,213$ \\
\hline Corporate sector & -222 & -222 & -222 & -889 & -903 & -482 & $-2,524$ \\
\hline Portfolio investment and financial derivatives (net) & 60 & 40 & 40 & 467 & 160 & 40 & 439 \\
\hline ST liabilities (inc. nonresident deposits) & -863 & $-1,447$ & -616 & $-3,882$ & $-2,709$ & -159 & $-7,672$ \\
\hline Trade credit (net) & -98 & 1 & -3 & -160 & -127 & 6 & -314 \\
\hline Total financing sources & 1,517 & 1,951 & 1,151 & 6,023 & 6,582 & 1,553 & 15,949 \\
\hline Current account & 235 & 274 & 269 & 832 & 1,080 & 256 & 1,672 \\
\hline Medium and long term debt & 325 & 386 & 325 & 1,174 & 2,554 & 1,070 & 5,470 \\
\hline Public sector & 0 & 0 & 0 & 3 & 0 & 0 & 153 \\
\hline MFIs & 147 & 208 & 147 & 549 & 1,832 & 684 & 3,565 \\
\hline Corporate sector & 178 & 178 & 178 & 622 & 722 & 386 & 1,751 \\
\hline Direct investment, net & 16 & 109 & 48 & 213 & 424 & 94 & 631 \\
\hline Capital account inflows & 80 & 80 & 80 & 380 & 320 & 80 & 854 \\
\hline Other & 149 & 3 & 3 & -393 & 10 & -3 & 30 \\
\hline Prospective official financing (exc. IMF) & 0 & 1,400 & 700 & 3,100 & 2,400 & 300 & 5,800 \\
\hline Change in gross reserves (increase -) & 561 & -452 & -424 & 156 & $-1,005$ & -443 & -516 \\
\hline Financing gap & 0 & 197 & 197 & 393 & 590 & 104 & 1,670 \\
\hline Prospective Fund credit & 0 & 197 & 197 & 394 & 590 & 104 & 1,670 \\
\hline
\end{tabular}

Sources: IMF staff estimates and projections.

1/ Rollover assumptions: 0 percent throughout for government and state banks in 2009 and 2010; 70 percent in 2009 and 90 percent in 2010 for foreign affiliated banks; 30 percent in 2009 and 50 percent in 2010 for other domestic banks; and 80 percent thoru 
Table 18. Latvia: Indicators of Fund Credit, 2008-14

(in millions SDR)

\begin{tabular}{lrrrrrr}
\hline & 2009 & 2010 & 2011 & 2012 & 2013 & 2014 \\
\hline Proposed Stand-By Arrangement & & & & & & \\
Purchases & & & & & & \\
$\quad$ Stock 1/ & 892 & 1428 & 1522 & 1232 & 663 & 204 \\
$\quad$ Obligations & 9.2 & 33.3 & 43.6 & 331.9 & 598.6 & 469.9 \\
$\quad$ Repurchase 2/ & 0.0 & 0.0 & 0.0 & 290.0 & 568.8 & 459.1 \\
$\quad$ Charges & 9.2 & 33.3 & 43.6 & 41.9 & 29.8 & 10.8 \\
Stock of existing and prospective Fund credit & & & & & & \\
In percent of quota & 704 & 1126 & 1200 & 971 & 523 & 161 \\
In percent of GDP & 5.3 & 9.3 & 9.9 & 7.7 & 3.9 & 1.1 \\
In percent of exports of goods and services & 14.6 & 22.6 & 22.3 & 16.7 & 8.4 & 2.4 \\
In percent of gross reserves & 30.7 & 37.4 & 30.7 & 19.8 & 9.3 & 2.5 \\
Obligations to the Fund from existing and prospective Fund arrangements & & & \\
In percent of quota & 7.2 & 26.3 & 34.4 & 261.8 & 472.1 & 370.5 \\
In percent of GDP & 0.1 & 0.2 & 0.3 & 2.1 & 3.5 & 2.6 \\
In percent of exports of goods and services & 0.1 & 0.5 & 0.6 & 4.5 & 7.6 & 5.5 \\
In percent of gross reserves & 0.3 & 0.9 & 0.9 & 5.3 & 8.4 & 5.7 \\
\hline
\end{tabular}

Source: IMF staff estimates.

1/ End-period.

2/ Repayment schedule based on repurchase obligations. 


\title{
LATVIA: LETTER OF INTENT
}

Riga, July 27, 2009

\author{
Mr. Dominique Strauss-Kahn \\ Managing Director \\ International Monetary Fund \\ Washington, DC, 20431 \\ USA
}

Dear Mr. Strauss-Kahn:

1. We are responding to the economic challenge facing Latvia with difficult but strong policy measures. Since the announcement of Latvia's macroeconomic programsupported by the EU, the IMF, and regional partners - the economic environment has deteriorated sharply. While policy implementation is hugely challenging, we are committed to containing external and fiscal imbalances, and preserving the long-standing exchange rate peg until our goal of euro adoption by 2014. Building on progress towards stabilizing the financial sector, our most urgent focus is on structural reforms needed to restore the public finances to health.

2. Since December, we have taken key steps to safeguard the financial system.

- Intervention capacity has been strengthened. A new Law on Bank Takeovers, amendments to the Law on Credit Institutions, Deposit Guarantee Law and the Financial and Capital Market Commission (FCMC) Law, as well as to the Bank of Latvia's regulations on emergency liquidity support have enhanced our capacity for bank intervention.

- We have improved supervision and monitoring. A targeted examination of all banks completed in March 2009 revealed no immediate solvency issues. The FCMC has enacted new regulations on asset quality assessment and provisioning, and issued supervisory guidance on banks' internal capital adequacy assessment processesshoring up capital buffers. The FCMC has also stepped up its monitoring of individual banks and enacted new reporting requirements.

- $\quad$ Stabilizing Parex. We have made progress towards stabilizing the second-largest bank, Parex. An agreement reached in March rescheduled the bank's syndicated loans. The government and the EBRD agreed in April on EBRD's investment of 
25 percent of Parex equity and a subordinated loan. The state recapitalized Parex in May.

3. We have also made considerable progress towards improving the legal framework to facilitate orderly and efficient debt restructuring. Recent amendments to the Insolvency Law, which entered into force on July 1, 2009, will facilitate out-of-court workouts by providing the incentive to restructure corporate debt and support rehabilitation of household debtors where needed. We have also developed a strategy to raise public awareness of the refined insolvency framework and to train government and private stakeholders to optimize out-of-court restructurings. Finally, we streamlined foreclosure procedures in March 2009 to speed up the debt resolution process. We have also developed a comprehensive private sector debt restructuring strategy, although without fiscal space a planned household debt restructuring scheme has been put on hold.

\section{The Bank of Latvia (BoL) comfortably met foreign currency reserve and} monetary targets under the program. After falling sharply in the first quarter $-a$ fall that culminated in consultation with staff on the basis of the program's consultation clause - net international reserves stabilized somewhat. The current account is now in surplus. But balance of payments pressures resulted from non-resident deposit outflows and the lowerthen-expected rollover of external debt. Meanwhile, residents switched from local- to foreign-currency deposits. Uncertainty about the exchange rate peg ahead of June's local elections renewed pressure on reserves. We addressed this in June through the adoption of a supplementary budget - a measure that helped boost confidence and allowed the central bank to start purchasing foreign exchange.

5. However the depth of the economic contraction has sharply reduced government revenues. This has made it impossible to fulfill fiscal targets without exacerbating already painful dislocations. On the basis of the 2009 corrective measures detailed below ( $\$ 13-15)$ and our plans for the future ( $\mid 20-24)$, we request waivers for the non-observance of the endMarch 2009 performance criterion on the fiscal deficit, and the continuous performance criterion on nonaccumulation of domestic arrears by the general government. And in light of the change of government in March, additional time was needed to prepare the supplementary budget. We are therefore also requesting a waiver for the end-March 2009 structural performance criterion on its submission to the Saeima.

6. Against this background and given the commitments we make below, we request completion of the First Review and Financing Assurances Review under the Stand-by Arrangement.

- $\quad$ Rephasing. We also request rephasing of the remaining purchases under the program - and smoothing of missed purchases over the program period owing to the slippage of reviews - with quantitative performance criteria for the Second Review to be assessed against end-September data and for the Third Review to be assessed 
against end-December data, with a return to quarterly reviews in 2010 . As such, the second and third reviews are expected to be completed on or after November 15, 2009 and February 15, 2010, respectively.

- Monitoring. The program will continue to be monitored through quantitative performance criteria and indicative targets, as well as a continuous performance criterion on the non-accumulation of domestic and external debt arrears of general government. Performance criteria and benchmarks through end-December 2009 are set out in Tables 2 and 3, as well as in the attached Technical Memorandum of Understanding.

\section{MACROECONOMIC FRAMEWORK FOR 2009-10}

7. The recession is much deeper than envisaged when the program was first agreed. With the bursting of the earlier bubble, there appears to have been a permanent negative shift in the level of potential output; domestic demand has collapsed; construction and consumer durables spending are particularly weak. Latvia's main trading partners are projected to contract by 5 percent in 2009, compared with previously envisaged modest growth. As a result, in the first quarter of 2009 real GDP fell 18 percent year-on-year. Registered unemployment has increased to 11 percent, but labor force survey estimates are higher at 14 percent.

\section{However, internal wage and price adjustment has begun, providing the} beginnings of a much-needed competitiveness boost. Headline inflation has fallen from 18 percent year-on-year mid-2008 to 3 percent in June 2009. Excluding VAT and excise increases, monthly inflation has been close to zero or negative for at least six months. Costs are falling. Gross wages per worker - after several years of rapid increases - fell 2 percent (seasonally adjusted) on end-2008 in the first quarter of 2009, compared with a 20 percent increase in 2008.

\section{We project that recovery will begin late 2010, albeit with further output losses} before then. Of course, there is considerable uncertainty around this. Real GDP is now projected to decline by 18 percent in 2009 , compared with 5 percent in the original program. For 2010, in forming our economic program, we project a further (year-average) contraction of 4 percent. However, we hope that economic conditions will improve faster than this. We also project falling wages through this period, though they remain unchanged as a share of national income. Falling domestic demand and wages will bring modestly falling prices: we expect the headline 12-month inflation rate to turn negative end-2009, and to average $3 \frac{1}{2}$ percent in 2010 .

\section{POLICIES FOR 2009-11}

10. Our macroeconomic strategy reflects our goal of euro adoption in 2014. This strategy helps address risks to households, enterprises, and banks from high levels of 
financial euroization. We recognize that meeting the Maastricht criteria for euro adoption requires difficult policy choices: double-digit fiscal consolidation to close a large structural general government deficit; tight monetary policy, consistent with the exchange rate peg; stronger financial sector supervision; and structural reforms to sustain economic recovery.

\section{A. Fiscal Policy}

\section{The 2009 supplementary budget was a critical first step towards sustainable} public finances. On June 16, Parliament adopted a supplementary budget, based on consultations with our social partners, intended to keep the 2009 fiscal deficit to 10 percent of GDP (ESA basis), or around 12 percent (general government net borrowing, GGNB; including net lending, but without bank restructuring costs). We remain committed to bringing the general government deficit down to 3 percent of GDP in 2012 - satisfying the Maastricht criterion for euro adoption. Given the deterioration in macroeconomic conditions which will likely cause further increases in the deficit, this will require an additional fiscal measures beyond 2009 of about 12-15 percent of GDP over 3 years. However, we recognize that this adjustment path is ambitious and, depending on events, may need to be revisited.

\section{Supplementary Budget}

\section{The 2009 supplementary budget is ambitious and includes a wide range of measures:}

- Revenue increases (about $1 / 2$ percent of GDP). We have increased dividends from state-owned companies; raised excise taxes on beer and alcohol; reduced the nontaxable personal allowance from 90 to 35 lats per month; and increased the gambling $\operatorname{tax}$.

- $\quad$ Net cuts in expenditure and net lending (about 3 percent of GDP). We have significantly reduced the budgets of ministries and state agencies where we are implementing structural reforms which draw in part on earlier World Bank recommendations. However, given the size of the necessary adjustment, we have also had to introduce additional across the board cuts, beyond these recommended structural reforms, which seek to increase the efficiency and quality of education, strengthen efficiency and targeting of healthcare services, make limited and targeted pension reductions, and reduce less targeted social spending. At the same time, the budget provides additional spending on unemployment benefits and protects EU-related spending.

\section{Safeguarding local government resources, social safety nets, EU-related} expenditure and other financial assistance is crucial. We will monitor local government budgets closely, especially those more resource-constrained municipalities outside larger cities, to ensure they can provide social assistance. To prevent undue social hardships, and in 
light of possible overruns from the implementation of 2009 budget, the fiscal deficit performance criterion includes a 1 percent of GDP cushion and is set at 13 percent of GDP.

14. We will provide funding of some $1 \frac{1}{2}$ percent of GDP in 2009 to expand social safety nets and accelerate the absorption of $\mathrm{EU}$ funds and other foreign financial assistance:

- $\quad$ Additional social safety net. We are working closely with the World Bank to design a comprehensive social safety net strategy. We will ensure appropriate funding of the measures by setting aside 1 percent of GDP of budget resources before midSeptember. In this context, as necessary, we will increase budget appropriations for unforeseen events, with the approval of the Parliamentary budget and finance (taxation) committee. Our plan includes:

Safeguarding appropriate financing of the guaranteed minimum income (GMI). We intend to increase the levels of GMI payments from LVL 37 to LVL 40 per adult and from LVL 37 to LVL 45 per child;

Covering patient copayments for healthcare services and pharmaceuticals in full for the most vulnerable, and partially for households earning less than half of the minimum wage;

Increasing funds for emergency housing support;

Ensuring the successful implementation of the new curriculum for 5 and 6 year olds;

Arranging temporary transportation solutions for children in communities affected by the education reform, pending permanent adjustments to our transport network in 2010 ;

Implementing active labor market policies and temporary public employment programs. We will organize public works programs for between 50,000 and 100,000 people for up to two years starting in the last quarter of 2009. In this context, we will reallocate 20 million lats from the European Social Fund (ESF).

- EU-financed expenditure and other foreign financial assistance:

We have ringfenced cash resources of some $6 \frac{1}{2}$ percent of GDP to ensure implementation by central and local governments of EU-funded projects in 2009. Net lending to local governments will be increased by LVL 51 million in 2009 as compared with 2008 to pre-finance EU and other foreign financed projects, and by LVL 10 million for near completed investment. In addition, LVL 5 million will be provided for heating subsidies. We intend to make full use 
of a new provision in the supplementary budget that allows local governments to enter multi-year commitments for EU projects subject to the approval of the Ministry of Finance.

We are developing a comprehensive plan to strengthen safeguards and increase efficiency in the use of EU funds.

\section{We will take immediate actions to reduce our level of commitments to help minimize risks to medium-term fiscal sustainability:}

- We have closed down the privatization fund and suspended the long term stabilization reserve for the duration of program; no extra-budgetary fund remains;

- We will not launch any new PPPs in 2009, except for four kindergarten building projects representing a total cost of LVL 10 million for their duration;

- We will not provide any net lending outside local governments, except for implementing EU- and other foreign financed projects or in the context of bank restructuring operations carried out in close consultation with EC and IMF staff;

- $\quad$ Similarly, with the exception of one-off guarantees currently committed or planned in the budget to Mortgage and Land Bank and Parex-related operations, we will permanently cap outstanding public guarantees at the level of the June supplementary budget (performance benchmark). Additional guarantees will only be issued if required for bank restructuring operations, and would then be issued after consultation with EC and IMF staff. Under this ceiling we will: (i) limit the liabilities of the Rural Development Fund below LVL 44 million and 3.5 times its capital level, and carefully control its guarantee policy; and (ii) tighten control over the Latvian guarantee agency. In addition, before September 1, 2009, we will review our risk assessment policy of guarantees to determine the size of appropriations required to cover these risks in time for the 2010 budget.

16. We will take all legal amendments and administrative measures necessary to implement the above decisions before end-September.

17. We will considerably strengthen the powers of the Minister of Finance and improve the capacity of the Finance Ministry; in addition, we will seek international assistance to strengthen implementation of our program. This includes:

- Technical assistance. We will set a medium-term TA plan in conjunction with EC, IMF, World Bank and other bilaterals covering: social safety nets, tax policy and administration, macroeconomic forecasting, public financial management, pension reform, liquidity management, debt and banking sector restructuring, deposit insurance, and civil service reform. 
- $\quad$ Revenue administration. We are expanding the large taxpayer unit operations to cover about 1,100 taxpayers representing 60-70 percent of domestic revenues collected by the State Revenue Service before September 30, 2009. We have also developed a plan to anticipate emerging risks to the tax system, assist distressed businesses to meet their tax obligations, and contain the rise in noncompliance.

- $\quad$ Public financial management will be strengthened through the following steps:

Commitment controls systems. We have already taken steps to strengthen the powers of the Minister of Finance to control budget execution. Before endDecember 2009, we will also: (i) amend the Law on Budget and Financial Management to allow the Ministry of Finance to exercise ex ante control of commitments on central government expenditure; (ii) take a cabinet decision that will help us to standardize commitment control systems across line ministries and institutions; and (iii) streamline the work of the Fiscal Discipline Management Committee to focus on commitments as well as cash. We will also work with local authorities to set standards on commitment control and budget execution procedures at the local government level.

Cash management. We will take steps to improve cash management, including for EU funds.

Other. Effective sanction procedures - besides those established by the Penal Code - will be introduced in law for any individual misuse of public money. The analytical capacity of the budget department of the Ministry of Finance will be significantly strengthened. Finally, we have granted veto powers to the Minister of Finance on any government decisions with a fiscal effect.

18. We acknowledge that the 2009 deficit will require significant domestic financing. We will also design new instruments in response to investor demand. We will not allow arrears to emerge, and our program includes a performance criterion to reflect this.

19. We also recognize that the 2009 budget is subject to implementation risks. We believe our across-the-board cuts are feasible, and our comprehensive social safety net strategy will mitigate the social risks associated with large scale reforms. In addition, we will consider reallocations or, as a last resort, providing additional funding where undue hardship emerges. Our resolve to continue fiscal adjustment next year and beyond will keep us on track even should we need to make small adjustments this year. This approach underlies the margins that we have built into the fiscal performance criteria for 2009.

\section{Budget}

20. We will implement measures to ensure a lower fiscal deficit in 2010 compared to this year. We are working closely with social partners to prepare whatever measures are 
necessary for this purpose. As explained in greater detail below, we will present to Parliament a 2010 budget consistent with this goal, along with any necessary legislation to implement the measures required (end-October structural benchmark). Our commitment is to limit the general government deficit to 8.5 percent of GDP (ESA basis) in line with the recommendation of the ECOFIN Council.

\section{We have already committed ourselves to introducing LVL 500 million (4 percent} of GDP) in targeted expenditure cuts and tax measures. To this end, we will implement the following measures and identify any further measures necessary to meet this objective as part of the 2010 budget process:

- A comprehensive plan to broaden the tax base of the personal income tax as of 2010, to include all capital income (including capital gains from real estate transactions), is under preparation. We will significantly reduce or remove most exemptions, including to farmers. We will reduce disparities in allowances across all sources of income, including pensions and wages. Together, these measures will yield 1 percent of GDP in revenues in 2010;

- We will abolish the special self-employed income tax regime, and bring the selfemployed into the standard personal income tax system from 2010. This will support tax compliance;

- We will design a comprehensive reform, allowing means-tested exemptions, to expand the base of the real estate tax to include all residential properties, on the basis of updated cadastral values. We believe that this could yield significantly more revenue (about 3/4-1 percent in GDP from 2011 onwards) than previously envisaged, be less distortionary, and more socially just. A transitory regime is required in 2010, as no means-tested exemptions will be available, but a flat tax will yield about $1 / 2$ percent of GDP in revenues. We will request international assistance to prepare this reform before December 31, 2009;

- We will carry out a broad public service reform. We will harmonize remunerations across ministries and institutions, significantly reducing wage inequalities by reviewing employment classifications (job families) and significantly tightening the wage grid. This reform should allow us to generate savings of at least $1 / 2$ percent of GDP in 2010 while retaining and appropriately compensating the most skilled public employees. We will also work with local governments to extend this reform to their own employees, creating a special law for remuneration system in local governments;

- We will not index pensions in 2010, pending the pension reform described below; 
- We will carry out a number of structural reforms prepared by a series of functional audits to generate sustainable savings of about 2 percent of GDP including in the following areas:

$>$ further consolidating agencies and line ministries' subordinated institutions, including in the economy (Public Utility Commission and the Competition Council), justice, and vocational and higher education sectors.

agriculture, environment and regional development: consolidating institutions and reducing state support, agricultural subsidies, and other miscellaneous subsidies including excise tax repayments to farmers;

culture: renegotiating the contract for the National Library project;

defense: cutting procurement and real estate costs, and reducing the size of the National Armed Forces; this will reduce the defense budget from 1.4 to about 1 percent of GDP;

$>$ foreign affairs: optimizing our network of embassies;

reducing Parliament's discretionary expenditure, for example the NATO Parliamentary Assembly in 2010;

social benefits: reduce the levels of social benefits while expanding social safety nets;

transport: reducing road maintenance and better targeting of public transport subsidies.

22. We have broadly identified additional measures totaling $2 \frac{1}{2}$ percent of GDP, and will implement measures of this scale as necessary as part of the 2010 budget to meet our objectives as laid out in paragraph 20. To this end, to the extent that the measures described in paragraph 21 above are insufficient, as part of the 2010 budget process we will identify and implement measures - including the following - which would be effective January 1, 2010, and estimated to yield 21/2 percent of GDP:

- Increase the headline VAT rate from 21 to 23 percent effective January 1,2010 (estimated to yield about $1 / 2$ percent GDP);

- $\quad$ Make the personal income tax system more progressive effective January 1, 2010, by raising the average effective tax rate to around 25 percent for people earning more than LVL 500 per month, through a graduated increase in the marginal rate (yielding $1 / 2$ percent of GDP); 
- Secure an additional $1 \frac{1}{2}$ percent of GDP of expenditure cuts during the budget process, including fundamental revisions in line ministries' budget bases.

23. We are prepared to take further measures to meet our fiscal objectives, in particular those objectives specified in paragraph 20 .

\section{1 and Beyond}

24. We intend to further reduce the deficit in 2011 and beyond, mostly through expenditure restraint. Our goal is to reach a deficit of 3 percent of GDP in 2012 (ESA basis), although we recognize that a more gradual adjustment path may be necessary. We will avoid further increases in the taxation of labor income so as not to undermine competitiveness. We have identified two areas where substantial further spending cuts are needed:

- $\quad$ Building on the public service reform in 2010, we will keep the public sector wages and salaries below 7 percent of GDP through further targeted wage cuts.

- In order to preserve the sustainability of the three pillars of our pension system, we will also prepare a pension reform with international assistance and in close cooperation with social partners before July 1, 2010. In this context, we will review all special pension regimes. It will be implemented from January 1, 2011.

\section{B. Monetary and Exchange Rate Policy}

25. The fixed (narrow band) exchange rate of the lats will remain the anchor for monetary policy until we adopt the euro. The credibility of the quasi currency board necessitates a conservative approach to monetary policy, and we will maintain existing limits to market operations and ensure that the BoL's liquid liabilities remain fully backed by its net international reserves. Further changes in official interest rates and minimum reserve requirements will be undertaken after prior consultation with IMF staff.

26. Monetary policy will respond to the Treasury's new policy of exchanging program financing exclusively off market at the BoL. To ensure this does not lead to excessive volatility in liquidity and interest rates, we will activate our available instruments, including deposit auctions, where necessary. In cooperation with international experts, we will continue to enhance our approach to liquidity management, adding new instruments where necessary and if consistent with the constraints posed by the quasi currency board. Finally, the Bank of Latvia intends to lower wages in line with market developments. 


\section{Financial Sector}

27. The FCMC will complete forward-looking assessments to ensure banks maintain adequate liquidity and solvency buffers throughout the program period. These assessments will build on the recent focused examination, and involve both top-down (performed by BoL and FCMC) and bottom-up (performed by banks after half-year financial results audits) stress tests. These stress tests will be based on extreme but realistic macroeconomic scenarios, agreed with IMF and World Bank staff. Results will be used to assess potential increases in own funds to build banks' solvency and liquidity buffers. Moreover, given the significant presence of foreign subsidiaries in Latvia, we recognize the need for close cooperation with the home authorities of these banks.

28. We will accelerate our development of a comprehensive bank resolution strategy (end-August 2009 structural benchmark). The strategy will set out: (i) responsibilities of various government agencies; (ii) the decision-making process, including options and methods for intervening in various sub-groups of banks; and (iii) plans for individual stateowned and private banks based on the forward-looking assessments noted above. We will discuss drafts with IMF and EC staff.

29. In the event that capital increases are necessary, we will seek private solutions for banks where possible - especially in view of fiscal constraints. Bank owners should be the primary providers of resources to cover losses. But we will encourage them to explore opportunities for co-financing capital increases through funding offered by the February 2009 joint EBRD, EIB and World Bank Group Joint Action Plan for CEE banks. We will also develop contingency plans for dealing with bank failures where shareholders cannot recapitalize banks.

30. The FCMC will introduce a more risk-oriented approach to supervision and regulation, including by:

- Strengthening off-site monitoring and analytical capacity (end-August 2009 structural benchmark). We will seek international assistance to refine our stress testing methodology. The BoL will share regular stress-test results, including methodologies with the FCMC; while these scenarios will be developed jointly between the BoL and FCMC. The FCMC will be given adequate resources to effectively carry out these tasks, and will incorporate stress testing results into off-site supervision and analytical activities.

- Addressing vulnerabilities. We will rigorously enforce newly enacted regulations. By revising liquidity regulations in line with best international practice, we will revisit our tolerance of liability concentrations and banks' reliance on short-term external funding. We will enforce best international practice for loan review systems 
and provisioning in banks, as well as prudential treatment of special entities set up by banks for the management of seized property and other problem assets.

31. We will continue our efforts to resolve Parex's problems. Priority will be given to ensuring adequate capitalization and stable management. To this end, the government has selected an international investment bank as its transaction advisor. The FCMC will continue monitoring Parex's liquidity, ensuring that management's restructuring plans do not entail undue risks. The government will engage the EBRD on assistance for bank restructuring.

\section{We remain committed to a fair and equitable treatment of depositors and} creditors in the Latvian banking system. Under our deposit insurance system, we are committed to respect the rights of all depositors, both resident and non-resident. We will remove the partial freeze limiting withdrawal amounts from deposits in Parex as conditions stabilize. We continue good-faith efforts to facilitate the settlement of affected depositors' claims arising from this exchange measure.

33. We will refocus the Mortgage and Land Bank on core activities. Commercial banking operations will be minimized as we focus the bank on activities crucial for the economy at this time - financing SMEs, business start-ups, infrastructure, and other national development projects. By end-September we will devise an appropriate strategy to maximize the bank's effectiveness in this task, we will establish an inter-institutional task force as well as seek international assistance. Until the strategy is finalized, the bank will refrain from assuming new foreign borrowing.

\section{We will refine our contingency planning and crisis management capacity:}

- $\quad$ Contingency planning. Meetings will discuss financial sector vulnerabilities with particular attention to contingency plans for specific institutions.

- $\quad$ Liquidity triggers. Internal FCMC guidelines will establish explicit liquidity triggers for supervisory actions in banks receiving emergency liquidity assistance as envisaged by the BoL ELA framework. The guidelines will include a range of actions with specific triggers, from close monitoring of liquidity, through restrictions on bank's business activities, to appointing the FCMC official to oversee bank's activities.

- Bank resolution. A comprehensive review of our bank resolution framework will guide legislative changes needed to bring the framework in line with best international practice. We will focus on ensuring that FCMC regulations and procedures are in line with recently enacted legislation.

- Deposit guarantee. International assistance will be sought to improve operational aspects of the Deposit Guarantee Fund; e.g., by setting up an autonomous department and designating trained staff to perform its functions. 


\section{Private Debt Restructuring}

35. We recognize the need for a debt restructuring strategy compatible with fiscal constraints. Our strategy for resolving and recapitalizing banks will increase their capacity to restructure debts and provision and recapitalize accordingly. We thus intend to base our strategy on restructuring corporate and household debt on a market-based approach. We are considering offering subsidized loans to qualifying household borrowers for their restructured mortgage loans in order to help them cope with economic distress, prevent foreclosures and create incentives for banks to provide debt relief when necessary. However, we are acutely aware of the lack of fiscal space, and will study further, in consultation with EC and Fund staff, how such a scheme could be financed, the degree to which its costs could be accommodated within the envelope of unavoidable bank restructuring costs, and how to ensure the scheme is optimally targeted.

\section{We will further improve the legal framework to help address widespread debt} distress in the corporate and household sectors. With limited prior debt restructuring experience in Latvia, we will issue by mid-August 2009 a set of guidelines on out-of-court corporate debt restructuring to set out general principles and process in line with international best practice. In addition, a further review of the Insolvency Law and other credit enforcement laws is underway with international assistance. Revisions will, inter alia, streamline liquidation procedures to facilitate rapid exit of non-viable firms, and further improve the foreclosure process by addressing remaining inefficiencies that hinder debt resolution. We will submit to Parliament the relevant amendments to these laws by endOctober 2009 (structural benchmark).

\section{E. Other issues}

37. Reforming the wage-setting mechanism is a priority. We will review the new public-sector wage grid to minimize discrepancies in pay between similar positions and skill levels across institutions by narrowing salary ranges for specific grades. In addition, we will monitor public-sector wage cuts to encourage an equitable burden of adjustment across all public sector institutions. A comprehensive report on proposed revisions to the public-sector wage grid and the relative wage adjustment across public institutions since end-December will be published by end-October 2009 (structural benchmark). We will also reform the Committee to Promote Wage Restraint by involving the social partners and outside labor market experts by end-August (structural benchmark). Its mandate will be amended to: (i) monitor private-sector wage developments, as well as the implementation of public sector wage cuts; and (ii) issue recommendations to ensure future compensation evolves in line with productivity. The committee will be subordinated to the National Tripartite Co-operation Council. Its monthly reports will be presented to the Prime Minister and Parliament, and published. 
38. We will implement in full the conclusions of the recent Safeguards Report. We recently adopted a memorandum of understanding between the Treasury and BoL requiring the Treasury to deposit all major foreign exchange holdings with the BoL. Henceforth, as noted earlier, the Treasury will exchange all international support from the Fund and other program partners off-market. In addition, to increase transparency, all long-term funds under the program will be disbursed to special sub-accounts of the Treasury's euro-account at the BoL, with one account ring-fenced for banking sector support and the other for budget support. We will report daily on the balances in these accounts, and the accounts of other program partners. Should the program accounts intended for budget support fall by more than EUR 250 million in any 30-day period, the Ministry of Finance will consult with IMF staff.

\title{
III. IMF ARRANGEMENT
}

39. We believe the policies described above will achieve the goals of our economic program: maintenance of the exchange rate peg; macroeconomic stability; and staying the course for euro adoption. Nevertheless, we stand ready to take additional measures needed to keep the program on track. We will consult with the IMF (and other program partners) on the adoption of these measures and in advance of any revisions to the policies contained in this Letter in accordance with the IMF's policies on such consultation. In addition, we will supply such information as the IMF requests on policy implementation and achievement of program objectives.

40. We authorize the IMF to publish this Letter of Intent and its attachments (including the Technical Memorandum of Understanding), and the related staff report.

Sincerely Yours,

\author{
Valdis Dombrovskis /s/ \\ Prime Minister
}

Einars Repše /s/

Minister of Finance
Ilmārs Rimšēvičs /s/
Governor of the Bank of

Latvia

Irēna Krūmane /s/

Chairwoman

Financial and Capital Market Commission

Ģirts Valdis Kristovskis /s/

Civic Union
Roberts Zīle /s/

For Fatherland and Freedom 
Solvita Āboltina /s/

New Era

Mareks Segliņš /s/

People's Party
Mārtiṇš Roze /s/

Union of Greens and Farmers 
Table 1. Latvia: Structural Conditionality under the Stand-By Arrangement, 2008-09

\section{Structural Performance Criterion}

1 Submission to Parliament of a second supplementary budget for 2009 to define spending allocations across ministries and spending agencies, and to identify clear programs that should be rationalized (March 31 , 2009).

\section{Structural Benchmarks}

1 Cabinet of Ministers to adopt decision that reforms controls over budget execution (December 31, 2008).

2 Adopt operational guidelines clarifying procedures for provision of emergency liquidity assistance (December 31, 2008).

3 National Tripartite Co-operation Council to establish a Committee to Promote Wage Restraint (January 31, 2009).

4 Review and, if necessary, revise regulations on emergency liquidity support (January 31, 2009)

5 Complete focused examination of the banking system (March 31, 2009).

6 Develop comprehensive debt restructuring strategy (April 30, 2009).

$7 \quad$ Amend banking laws to give FCMC, BoL and Government powers to restore financial stability in case of systemic crisis (June 30, 2009).

8 Adopt an amendment to the Budget and Financial Management law to strengthen financial responsibility, transparency and accountability (June 30, 2009).

9 Amend insolvency law to facilitate orderly and efficient debt restructurings (June 30, 2009).

\section{Status}

Second supplementary

budget submitted to

Parliament, and

approved, in June 2009.

Done.

Done.

Done.

Done.

Done.

Done in June 2009.

Done.

In progress. Some amendments to strengthen powers of Minister of Finance adopted.

Done. 
Table 2: Latvia: Quantitative Performance Criteria and Indicative Targets under the Stand-By Arrangement, 2008-09 (In millions of lats unless otherwise indicated)

\begin{tabular}{|c|c|c|c|c|c|c|c|c|c|}
\hline & \multicolumn{3}{|c|}{2008} & \multicolumn{6}{|c|}{2009} \\
\hline & \multirow{2}{*}{$\begin{array}{c}\text { end-Nov } \\
\text { Actual }\end{array}$} & \multirow{2}{*}{\multicolumn{2}{|c|}{ end-Dec }} & \multirow{2}{*}{\multicolumn{2}{|c|}{ 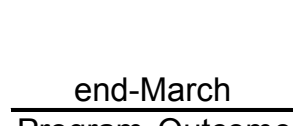 }} & \multirow{2}{*}{\multicolumn{2}{|c|}{ end-June }} & \multicolumn{2}{|c|}{ Proposed } \\
\hline & & & & & & & & End-Sept & End-Dec \\
\hline \multicolumn{10}{|l|}{ I. Quantitative performance criteria } \\
\hline $\begin{array}{l}1 \text { Floor on net international reserves of the Bank of Latvia } \\
\text { (millions of euros) }\end{array}$ & 3,368 & 2,103 & 2,700 & 737 & 1,733 & -507 & 1,163 & -81 & -586 \\
\hline 2 Ceiling on net domestic assets of the Bank of Latvia & -99 & 951 & 423 & 1,434 & 419 & 2,501 & 768 & 1,719 & 2,103 \\
\hline 3 Floor on adjusted cash fiscal balance & $\cdots$ & -894 & -957 & -305 & -328 & -649 & -794 & $\cdots$ & $\ldots$ \\
\hline 4 Floor on adjusted primary cash fiscal balance & $\cdots$ & $\cdots$ & $\ldots$ & $\cdots$ & $\cdots$ & $\cdots$ & -388 & -828 & $-1,289$ \\
\hline 5 Ceiling on public guarantees (millions of lats) & $\ldots$ & $\ldots$ & $\ldots$ & $\cdots$ & $\cdots$ & $\cdots$ & $\ldots$ & 754 & 754 \\
\hline \multicolumn{10}{|l|}{ II. Continuous performance criteria } \\
\hline $\begin{array}{l}6 \text { Non-accumulation of general government domestic } \\
\text { arrears }\end{array}$ & $\ldots$ & 0 & 0 & 0 & 6 & 0 & 11 & 40 & 40 \\
\hline $\begin{array}{l}7 \text { Non-accumulation of external debt arrears } \\
\text { (millions of euros) }\end{array}$ & $\ldots$ & 0 & 0 & 0 & 0 & 0 & 0 & 0 & 0 \\
\hline \multicolumn{10}{|l|}{ III. Staff consultation clause } \\
\hline $\begin{array}{l}8 \text { If sub-accounts for program budget support fall by more } \\
\text { than } € 250 \text { million in any } 30 \text {-day period }\end{array}$ & $\ldots$ & $\ldots$ & $\cdots$ & $\cdots$ & $\cdots$ & $\cdots$ & $\cdots$ & & \\
\hline \multicolumn{10}{|l|}{ IV. Indicative target } \\
\hline 9 Ceiling on the general government wage bill & $\ldots$ & 1,248 & 1,267 & 214 & 263 & 490 & 598 & 840 & 1,067 \\
\hline
\end{tabular}


Table 3. Latvia: Structural Benchmarks through end-December 2009

\section{Structural Benchmarks}

Target date

1 Wages: reform the Committee to Promote Wage Restraint by involving the social partners and outside labor market experts.

2 Wages: prepare a comprehensive report on proposed revisions to the public-sector wage grid and the relative wage adjustment across public institutions since endDecember.

3 Prepare a strategy for bank recapitalization and resolution.

4 Financial sector monitoring: (i) seek international assistance to improve stress-testing capacity; strengthen co-operation between the BoL and FCMC in this area; and (ii) increase resources available to FCMC to perform off-site monitoring incorporating results of stress-tests.

5 Design a strategy to strengthen the social safety net.

6 Submission to Parliament of amendments to the Insolvency Law and other credit enforcement laws.

7 Adopt an amendment on fiscal responsibility to the current Budget and Financial Management Law that will aim to reduce public debt, set expenditure ceilings, avoid procyclicality in fiscal policy and ultimately allow automatic stabilizers to operate fully.
End-Aug 2009

End-Aug 2009

End-Aug 2009

End-Oct 2009

End-Aug 2009

End-Oct 2009

End-Dec 2009 


\section{Attachment II. Latvia: TeChniCal Memorandum of Understanding (TMU)}

July 27, 2009

1. This Technical Memorandum of Understanding (TMU) defines the variables subject to quantitative targets (performance criteria and indicative targets) established in the Letter of Intent dated July 27, 2009 signed by the Prime Minister, the Minister of Finance, the chairwoman of the Financial and Capital Market Commission, the Governor of the Bank of Latvia, and coalition partners. It describes the methods to be used in assessing program performance with respect to these targets.

For program purposes, all foreign currency-related assets, liabilities, and flows will be evaluated at "program exchange rates" as defined below, with the exception of the government fiscal balances, which will be measured at current exchange rates. The program exchange rates are those prevailing on November 28, 2008. In particular, the exchange rates for the purposes of the program of the Latvian Lat (LVL) to the euro is set at LVL 0.702804 $=€ 1$, to the U.S. dollar at LVL $0.544=\$ 1$, and to the Japanese yen at LVL $0.00571=1 \mathrm{JPY}$, as shown on the Bank of Latvia (BoL) website.

\section{A. Floor on Net International Reserves of the BoL}

(in million euros)

Outstanding stock:

$\begin{array}{ll}\text { June } 30,2009 & 1,163\end{array}$

Floors on level of NIR:

September 30, 2009 (performance criterion) $\quad-81$

December 31, 2009 (performance criterion) $\quad-586$

\section{Definitions}

2. For program purposes, the following definitions apply:

- $\quad$ Net international reserves (NIR) of the BoL are the difference between the BoL's foreign reserve assets and the BoL's foreign reserve liabilities, minus Treasury liabilities to the IMF, the European Union, other official creditors participating in the program. If not otherwise captured under this definition, assets associated with SDR allocations will be added to NIR assets, and liabilities associated with SDR allocations will be added to NIR liabilities.

- $\quad$ Foreign reserve assets of the BoL are claims on nonresidents denominated in convertible currencies. They include the BoL's holdings of monetary gold, SDRs, 
foreign currency cash, foreign currency securities, deposits abroad, participating interests in the European Central Bank and the Bank for International Settlements, and other foreign assets. Excluded from foreign reserve assets are any assets that are frozen, pledged, used as collateral, or otherwise encumbered, except if already included as foreign liabilities, precious metals other than gold, assets in nonconvertible currencies, and illiquid assets. As of June 30, 2009, foreign reserve assets thus defined amounted to 2,913 million euro.

- $\quad$ Foreign reserve liabilities of the BoL comprise all liabilities to nonresidents, including commitments to sell foreign exchange arising from derivatives (such as futures, forwards, swaps, and options) and banks foreign currency deposits against reserve requirements. Government foreign exchange deposits with the BoL are not treated as a foreign reserve liability. As of June 30, 2009, reserve liabilities thus defined amounted to 132 million euro.

- $\quad$ Base money is defined as lats in circulation (both outside banks and vault cash), required and excess reserve deposits of financial institutions in lats and in foreign currency held at the BoL (excluding financial sector funds deposited in the BoL's deposit facility and in term deposits in the BoL). As of June 30, 2009, base money equaled 1,585 million lats.

- $\quad$ Net domestic assets (NDA) of the BoL are defined as base money minus the net foreign assets (NFA) of the BoL, plus Treasury liabilities to the IMF, the European Union and other official creditors participating in the program, expressed in local currency, at program exchange rates. If not otherwise captured under this definition, assets associated with SDR allocations will be subtracted from NDA, and liabilities associated with SDR allocations will be added to NDA.

- $\quad$ Net foreign assets of the BoL are the difference between the BoL's foreign reserve assets and the BoL's foreign reserve liabilities defined above, plus those foreign reserve assets of the BoL that were excluded from the above definition. As of June 30, 2009, net foreign assets of the BoL amounted to 1,955 million lats.

As of June 30, 2009 the sum of Treasury liabilities to the IMF, the European Union, other official creditors participating in the program, and other external borrowing by the Treasury over the program period, amounted to 1,619 million euros.

The ceilings set out below are based on the assumption that all program related financing will be given to the Latvian government and will be deposited in a special sub-account of the Treasury euro-account at the BoL.

If the reserve requirement ratio and/or the definition of liabilities subject to reserve requirements is changed during the program period, the BoL will consult with the IMF staff to modify the above limits appropriately 


\section{B. Ceiling on Net Domestic Assets of the BoL}

(in million lats)

Outstanding stock:

June 30, 2009

Ceiling on level of NDA:

September 30, 2009 (performance criterion) $\quad 1,719$

December 31, 2009 (performance criterion) 2,103

\section{Adjustor}

So as to not constrain legitimate provision of emergency liquidity assistance (ELA) - subject to the limits implied by Latvia's quasi currency board arrangement - the NDA ceiling will be adjusted upwards (and correspondingly the NIR target will be revised down) by the amount of any new ELA (beyond that currently outstanding), provided that net foreign assets of the BoL remain above base money.

\section{Floor on the Adjusted Primary Cash Fiscal Balance of the General Government}

(in million of lats)

Cumulative adjusted primary cash fiscal balance from

January 1, 2009:

June 30, 2009 (preliminary estimate) $\quad-357$

September 30, 2009 (performance criterion) $\quad-828$

December 31, 2009 (performance criterion) $\quad-1,289$

The general government includes: (i) the central government, including all ministries, agencies and institutions attached thereto, as defined in the basic budget; (ii) derived public persons, including universities; (iii) the social security fund (first pillar), as described in the special budget; (iv) municipalities, provincial, regional governments including their basic and special budgets, including all agencies and institutions attached thereto, which are classified as part of general government according to the budget documents and which are included by the BoL in its monthly submissions to the IMF of balance sheets of the central bank and the consolidated accounts of the commercial banks. No off-budgetary funds will be maintained or created. This definition of general government also includes any new funds, or other special budgetary and extra-budgetary programs that may be created during the program period to carry out operations of a fiscal nature as defined in the IMF's Manual on Government Finance Statistics 2001. The authorities will inform IMF staff of the creation of any such new funds or programs immediately. 
The adjusted cash primary fiscal balance of the general government is defined as general government net lending/borrowing, in cash:

- excluding bank restructuring costs ( $(12)$ and any shortfall in contributions to the second pillar below the level of 8 percent of wages, applicable at the start of the program;

- $\quad$ plus interest expenditure;

- $\quad$ minus revenues from EU funds (reimbursements and advances) at the general government level (central and local governments);

- $\quad$ plus EU-related spending by the central government (including national co-financing and pre-financing), including transfers from the central budget to local governments for EU-related spending (excluding net lending).

Foreign financial assistance not managed by the European Commission is excluded from the revenues from EU-funds and from the associated spending.

The net government lending/borrowing includes all recognitions of liabilities by the general government unit. This includes in particular the following debt-related transactions: debt assumption (i.e. when the general government assumes responsibility for the debt as the primary obligor, or debtor), debt payments on behalf of others, debt forgiveness, debt restructuring and rescheduling, debt write-offs and write-downs, debt-for-equity swaps, and defeasance. For example, if a loan guarantee is called, the general government records a transfer to the defaulter and an incurrence of a liability to the creditor.

\section{Bank Restructuring Costs}

For program purposes, the cash fiscal balance of the general government excludes the restructuring costs of troubled banks, when carried out under the program's banking sector restructuring strategy. Costs that may be excluded from the cash balance include loans to financial institutions and investments in equity of financial institutions (requited recapitalization); unrequited recapitalization; and purchase of troubled assets. However, any financial operation from the general government to support banks, including the emission of guarantees or the provision of liquidities, will be immediately reported to IMF staff.

\section{Interest Revenues and Payments (Adjustor)}

The quarterly floor for the adjusted cash fiscal balance of the general government will be adjusted upwards starting in 2009 for interest receipts, dividends or capital gains from government deposits or investments in the banking system, including all revenues from the BoL, in excess of 15 million lats each quarter, cumulated from January 1.

Interest payments are recorded on a gross basis, net of interest payments within the general government. 


\section{Social Spending (Adjustor)}

The end-December floor for the adjusted cash primary fiscal balance of the general government will be adjusted upward for any shortfall in spending on additional social safety nets, as defined under the World Bank strategy, cumulated from January 1, 2009, below 104 million lats.

\section{Financing}

Consistent with the NDA ceilings in section B, the government will deposit all program related financing in a special sub-accounts of the Treasury euro-account at the BoL.

Furthermore, three-quarters of IMF program financing (about 150 million euros for the second tranche) will be placed in an account at the Bank of Latvia for budget support, with the remaining financing reserved for banking sector support. The accounts will be distinct from those receiving financing from other program partners, including the European Commission, which will be reported separately.

\section{Reporting}

The adjusted cash primary fiscal balance of the general government will be monitored and reported based on financing information (below-the-line) on a monthly basis, and reconciled with revenue and expenditure reports as soon as those become available, at the latest 30 days after the end of each month.

Revenues from EU funds at the general government level, EU-related spending by the central government, including transfers to local governments for EU-related spending, will be reported in details on a monthly basis, at the latest 30 days after the end of each month, distinguishing, for expenditure, between subsidies and transfers and capital expenditure.

\section{Ceiling on the General Government Wage Bill}

\begin{tabular}{lc}
\hline & (in million of lats) \\
\hline Wages and salaries in 2008 & 1267 \\
& \\
Wages and salaries (Cumulated from January 1, 2009): & 264 \\
March 31, 2009 (actuals) & 598 \\
June 30, 2009 (preliminary estimate) & 840 \\
September 30, 2009 (indicative target) & 1,067 \\
December 31, 2009 (indicative target) & \\
\hline
\end{tabular}

The ceiling on the general government wage bill includes general government (as defined above) wages and salaries, including allowances (including separation allowances) and bonuses. No in kind benefits will be increased or created during the program period. 
The end-September and end-December targets are based on a more conservative scenario on the pace of the wage adjustment than IMF staff's central estimates (1,036 million lats by endDecember).

\section{E. Ceiling on Public Guarantees}

The stock of outstanding guarantees issued by the general government and by all public agencies and enterprises, excluding public banks and their subsidiaries, will not exceed 754 million lats (about 5.5 percent of GDP in 2009) for the duration of the program:

- This ceiling includes all guarantees that can be issued or committed by the Latvian Guarantee Agency, the Rural Development Fund, or any other public agency or enterprise, excluding public banks;

- It does not include up to 313 million lats of one-off guarantees already issued, committed or planned in the June 2009 supplementary budget to Mortgage and Land Bank; however, further guarantees to Mortgage and Land Bank, except for bank restructuring operations ( $(\mid 23)$, will be counted under the ceiling on public guarantees;

- $\quad$ It does not include 541 million lats of guarantees already issued, committed or planned, at the date of June 2009 supplementary budget, to Parex or to the privatization agency for Parex-related operations;

- It does not include guarantees extended within the general government.

Consistent with the Law on budget and financial management, the estimated fiscal costs of guarantees will be covered by budget appropriations in the contingency reserve. The ceiling on public guarantees will only be raised if required for bank restructuring operations and after consultation with EC and IMF staff.

All public guarantees, excluding from public banks, will be reported in details on a monthly basis, distinguishing between central and local governments and their attached agencies and public enterprises, and identifying all amounts and beneficiaries.

\section{F. Continuous Ceiling on Domestic Arrears by the General Government}

General government domestic arrears are defined as amounts that have not been paid by the date specified in a contract or within a normal commercial period for similar transactions by the general government. This applies in particular to (i) all employment contracts and arrears thereby captured delayed wage payments to employees of the public sector and to (ii) mandatory contributions to the social insurance funds. The ceiling for arrears will be set at LVL 40 million for the duration of the program. As of end-June, the stock of arrears stood at LVL 11 million. This performance criterion will apply on a continuous basis. 


\section{G. Continuous Performance Criterion on Non-accumulation of External Debt Payments Arrears by the General Government}

The general government will accumulate no new external debt payments arrears during the program period. For the purposes of this performance criterion, an external debt payment arrear will be defined as a payment due to nonresidents by the general government, which has not been made within seven days after falling due. This performance criterion does not cover trade credits, or nonresident deposits in state-owned banks. This performance criterion will apply on a continuous basis.

The stock of external debt payments arrears of the general government will be calculated based on the reported schedule of external payments obligations. Data on external debt payments arrears will be reconciled with the relevant creditors, and any necessary adjustments will be incorporated in these targets as they occur.

\section{H. Monitoring and Reporting Requirements}

Performance under the program will be monitored from data supplied to the IMF by the BoL, the Financial and Capital Markets Commission, and the Ministry of Finance as outlined in Table 1. The authorities will transmit promptly to the IMF staff any data revisions. 
Table 1. Republic of Latvia: Data to be Reported to the IMF

To be provided by the
Item
Consolidated central (basic and special budgets), local
and general government operations based on the IMF
fiscal template
Detailed information on revenues from EU funds at the
general government level, and EU-related spending by
the central government, including transfers to local
governments for EU-related spending
Consolidated central and general government bank
restructuring operations
Privatization receipts received by the general
government budget (in lats and foreign exchange, and
payments in governments bonds)
Information on debt stocks and flows, domestic and
external (concessional and non concessional), by
currency, and guarantees issued by the (i) consolidated
central, local and general governments and (ii) public
enterprises (including the Latvian guarantee agency and
the Rural guarantee fund), including amounts and
beneficiaries
Information on new contingent liabilities, domestic and
external, of the consolidated central, local and general
governments
Data on general government arrears, including to
suppliers
Data on operations of extrabudgetary funds
Data on the stock of the general government system
external arrears

Periodicity

Daily, by end of next working day

Monthly, within four weeks of the end of each month

Monthly, within four weeks of the end of each month

Monthly, within four weeks of the end of each month

Monthly, within four weeks of the end of each month

Monthly, within four weeks of the end of each month

Daily, with a seven days lag

\section{To be provided by the Bank of Latvia}

Balance sheet of the BoL, including (at actual exchange rate) (i) data on components of program NIR; (ii)

government balances at the BoL, broken into foreign

exchange balances - distinguishing various program

partner sub-accounts for program financing - and

balances in lats.

Balance sheet of the BoL (in program and actual exchange rates) (i) data on components of program NIR;

Daily, within one working day

(ii) government balances at the $\mathrm{BoL}$, broken into foreign

exchange balances - distinguishing various program

partner sub-accounts for program financing - and

balances in lats.

Consolidated accounts of the commercial banks

Monetary survey

Weekly, within one week of the end of each week

Monthly, within two weeks of the end of each month Monthly, within two weeks of the end of each month 
Currency operations, including government foreign receipts and payments and breakdown of interbank market operations by currencies (interventions) Aggregated data on free collateral-available, unpledged collateral held at the Bank of Latvia Daily data with banks' current accounts, minimum reserve requirements, stock of repos and fx swaps Foreign exchange rate data

Volume of foreign exchange lats trades

Projections for external payments of the banking sector falling due in the next four quarters, interest and amortization (for medium and long-term loans) Projections for external payments of the corporate sector falling due in the next four quarters interest and amortization (for medium and long-term loans) The stock of external debt for both public and private sector

The BoL will continue to provide balance of payments data in electronic format.

\section{To be provided by the Financial and Capital Market Commission}

Daily deposit monitoring bank by bank in the agreed format

Daily detailed deposit monitoring in Parex Bank in the agreed format

Banking system monitoring indicators in the agreed format (liquidity, credit quality, summary capital adequacy, simplified balance sheet and income statements)

Detailed capital adequacy reporting in the agreed format Commercial banks' balance sheets (bank-by-bank) Commercial banks' income statements (bank-by bank)

Daily, by end of next working day
Daily, by end of next working day

Weekly, within one week of the end of each week

Monthly, capturing data over the preceding month, within one week of the end of the month

Daily, by end of next working day

Monthly (weekly for a sample of large banks), within one week of the end of each week

Quarterly, within four weeks of the beginning of the year

Annually, within three months after the end of the second quarter

Monthly, within four weeks of the end of each month for the public and the banking sector; quarterly, within three months of the end of each quarter for total external debt

Monthly, within six weeks of the end of each month

Monthly, within four weeks of the end of each month

Quarterly, within four weeks of the end of each quarter Quarterly, within four weeks of the end of each quarter Quarterly, within four weeks of the end of each quarter 


\section{INTERNATIONAL MONETARY FUND}

\section{REPUBLIC OF LATVIA}

First Review and Financing Assurances Review Under the Stand-By Arrangement, Requests for Waivers of Nonobservance of Performance Criteria, and Rephasing of Purchases Under the Arrangement-Informational Annex

Prepared by the European Department

(In Consultation with Other Departments)

Approved by Marek Belka and Reza Moghadam

August 7, 2009

Contents

\section{Appendix}

I. Fund Relations............................................................2

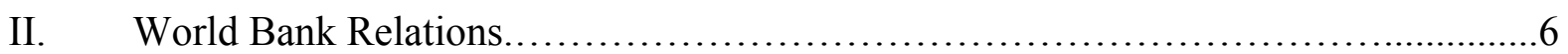




\section{APPENDIX I. LATVIA: FUND RELATIONS}

(As of July 29, 2009)

I. Membership Status: Joined May 19, 1992; Article VIII.

II. General Resources Account:

Quota

Fund holdings of currency

Reserve position in Fund

III. SDR Department:

Holdings

IV. Outstanding Purchases and Loans:

Standby Arrangement
SDR Million

126.80

662.11

0.06

SDR Million

0.41

SDR Million

535.34
Percent of Quota

100.0

522.17

0.04

Percent of Allocation

N.A.

Percent of Quota

422.20

V. Latest Financial Arrangements:

Type

Stand-by

Stand-by

Stand-by

Stand-by
Approval Date

$12 / 23 / 08$

$04 / 20 / 01$

$12 / 10 / 99$

$10 / 10 / 97$
Expiration Date

$03 / 22 / 11$

$12 / 19 / 02$

$4 / 9 / 01$

$4 / 9 / 99$
Amount

Approved (SDR million)

$1,521.63$

33.0

33.0

33.0
Amount Drawn

(SDR million)

535.34

0.00

0.00

0.00

VI. Projected Obligations to the Fund:

$\begin{array}{llllll} & \underline{2009} & \underline{2010} & \underline{2011} & \underline{2012} & \underline{2013} \\ \text { Principal } & 0.00 & 0.00 & 267.67 & 267.67 & 0.00 \\ \text { Charges/interest } & 3.95 & 7.87 & 6.86 & 3.07 & 0.15 \\ \text { Total } & 3.95 & 7.87 & 274.53 & 270.74 & 0.15\end{array}$

\section{Exchange Arrangements:}

The currency of Latvia is the lats, which was introduced in March 1993 to replace the Latvian ruble. The exchange rate was pegged to the SDR from February 1994 to December 2004, within a \pm 1 percent band. On January 1, 2005, the lats was repegged to the euro at the rate $€ 1=0.702804$ lats, and on April 29, 2005, Latvia entered ERM2, maintaining the previous band width. On July 29, 2009 the lats was equal to US\$2.03. Latvia's exchange system is free of restrictions on the making of payments and transfers for current international transactions. Latvia maintains security-related exchange restrictions pursuant to UN Security Council resolutions and EC Council regulations, which have been notified to the Fund under Decision No. 144-(52/51), adopted August 14, 1952. Latvia also maintains a partial deposit freeze on Parex Bank, which gives rise to an exchange restriction. 
However, as it has been imposed for balance of payments reasons, is temporary and is nondiscriminatory, the board has approved its retention until end-November 2009 or the conclusion of the next Article IV, whichever comes earlier.

\section{Article IV Consultation:}

Latvia is on the 24-month consultation cycle.

The 2006 Article IV staff report was issued on September 13, 2006 (Country Report No. 06/353). The last Article IV Board discussion took place on October 4, 2006. The Public Information Notice No. 06/113 was released on October 12, 2006.

\section{Safeguards Assessment}

A safeguards assessment of the Bank of Latvia was conducted in October 2001 and an update assessment was concluded on July 8, 2009. The update assessment confirmed that the BoL has a relatively strong safeguards framework in place. Recommendations for further improvements were made in the legal structure and independence, financial reporting, and internal control areas.

\section{FSAP Participation and ROSCs:}

A joint World Bank-International Monetary Fund mission conducted an assessment of Latvia's financial sector as part of the Financial Sector Assessment Program (FSAP) during February 14-28, 2001. The Financial Sector Stability Assessment (FSSA) report was discussed at the Board on January 18, 2002, together with the 2001 Article IV staff report (Country Report No. 02/10). An AML/CFT assessment mission took place during March 8-24, 2006, and the report was sent to the Board on May 23, 2007. A joint IMF-World Bank mission conducted an FSAP Update during February 27-March 9, 2007.

\section{ROSC Modules}

Standard/Code assessed

Code of Good Practices on Fiscal Transparency

Code of Good Practices on Transparency in Monetary and Financial

Policies

Basel Core Principles for Effective Banking Supervision

CPSS Core Principles for Systemically Important Payment Systems

IOSCO Objectives and Principles of Securities Regulation

IAIS Core Principles

OECD Corporate Governance Principles

Data Module
Issue date

March 29, 2001

January 2, 2002

January 2,2002

January 2, 2002

January 2, 2002

January 2, 2002

January 2, 2002

June 23, 2004 


\section{Technical Assistance (2004-09):}

DEPT

Project

FAD Budget Reforms

FAD Expenditure Policy

FAD Tax Policy

FAD Revenue Administration

MCM Bank Resolution

FAD Public Financial

Management

$\mathrm{MCM} /$

LEG

LEG

Legal Aspects of

P\&A Transactions

MCM Bank Intervention procedures and P\&A

FAD Public Financial

Management

FAD Revenue Administration

FAD Cash Management
Action

Mission

Mission

Mission

Mission

Mission

Mission

Mission

Mission

Mission

Mission

Mission

Mission

\section{Timing}

January 2004

June 2007

March 2008

January 2009

January 2009

March 2009

March 2009

Feb-March 2009

March 2009

April-May 2009

July 2009

July-August 2009
Counterpart

Ministry of Finance

Ministry of Finance

Ministry of Finance

Ministry of Finance

FCMC, Bank of Latvia

Ministry of Finance

Ministry of Finance, FCMC

FCMC

FCMC

Ministry of Finance

Ministry of Finance

Ministry of Finance 


\section{Resident Representative:}

Mr. David Moore has been appointed Resident Representative effective from June 11, 2009.

\section{Fourth Amendment:}

Latvia accepted the Fourth Amendment of the Articles of Agreement on February 16, 2001. 


\section{APPENDIX II. LATVIA: WORLD BANK RELATIONS}

(As of July 29, 2009)

Table 1. Latvia: Bank and Fund planned activities in macro-critical structural reform areas, July 2009-June 2010

\begin{tabular}{|c|c|c|c|}
\hline Title & Products & $\begin{array}{c}\text { Provisional Timing of } \\
\text { Missions }\end{array}$ & Expected Delivery Date \\
\hline \multirow{4}{*}{$\begin{array}{l}\text { 1. Bank } \\
\text { Work } \\
\text { Program }\end{array}$} & Regional Framework Paper & In preparation & Expected in the Fall 2009 \\
\hline & $\begin{array}{l}\text { Social Sector, Public } \\
\text { Administration Reform and } \\
\text { Emergency Safety Net - } \\
\text { Development Policy Loan }\end{array}$ & In preparation & $\begin{array}{l}\text { Board approval expected } \\
\text { in September } 2009\end{array}$ \\
\hline & $\begin{array}{l}\text { Financial Sector - Development } \\
\text { Policy Loan }\end{array}$ & In preparation & $\begin{array}{l}\text { Board approval expected } \\
\text { in September } 2009\end{array}$ \\
\hline & Swiss Cohesion Fund TA & Under discussion & $\begin{array}{l}\text { Implementation } \\
\text { throughout fiscal } \\
\text { year } 2010\end{array}$ \\
\hline \multirow[t]{2}{*}{$\begin{array}{l}\text { 2. Fund } \\
\text { Work } \\
\text { Program }\end{array}$} & $\begin{array}{l}\text { TA on cash management } \\
\text { TA on refocusing the Mortgage } \\
\text { and Land Bank }\end{array}$ & $\begin{array}{l}\text { August } 2009 \\
\text { August/September } 2009\end{array}$ & $\begin{array}{l}\text { August } 2009 \\
\text { September } 2009\end{array}$ \\
\hline & Staff Visit (Fiscal) & September 2009 & September 2009 \\
\hline
\end{tabular}




\section{Statement by the Staff Representative on the Republic of Latvia Executive Board Meeting August 27, 2009}

1. This statement reports on recent developments since the issuance of the Staff Report.

2. These developments do not alter the thrust of the staff appraisal, and underline thedepth of the contraction. Real GDP in the second quarter of 2009 declined by 19.6 percent year on year, according to preliminary data, broadly in line with projections in the staff report. The unemployment rate (labor force survey basis) increased to 16.7 percent in the second quarter, up from 14 percent in the first quarter and around 6 percent in the second quarter of 2008. After stabilizing in April and May, retail sales fell 5 percent in June. And following a sharp fall in 2008, industrial output has stabilized at the start of this year, and grew by 1.4 percent seasonally adjusted in June. However, the sector accounts for less than 15 percent of GDP.

3. Consumer price inflation has continued to fall. The 12-month CPI inflation rate fell to 2.5 percent in July, from 3.4 percent in June. On a month-on-month basis, prices fell by 0.6 percent, the fourth consecutive month of price declines. Producer prices fell 8.4 percent in July compared to one year earlier.

4. The current account surplus has widened significantly, reaching 2 percent of annual GDP in June alone. In large part this reflected foreign banks' losses (largely due to write-offs), which are recorded as a credit item in the income account, with a counter-entry in the capital account. That said, in June for the first time this decade Latvia recorded an overall surplus on goods and services. The cumulative current account surplus in the first half of the year has reached 4 percent of annual GDP, and the program projection for the year as a whole will likely need to be increased. The nominal and real effective exchange rates were stable in July, and have appreciated by $3 \frac{1}{2}$ percent and 3 percent respectively since December 2008.

5. Financial market pressures have eased. Since early July, neither the Bank of Latvia nor the Treasury has bought or sold foreign exchange vis-à-vis the private sector. Since the start of August, overnight interest rates have remained below 5 percent. However, the situation remains fragile. On August 10, Standard \& Poor's downgraded its sovereign rating from $\mathrm{BB}+$ to $\mathrm{BB}$, with a negative outlook, pointing to the political and economic challenges facing Latvia as a result of rapidly contracting nominal and real incomes and the associated pressures on public finances.

6. The Latvian government has decided to proceed with a L43 million (€60 million, or 0.3 percent of GDP) recapitalization of the state-owned Mortgage and Land Bank. This transaction, which will be recorded as budget expenditure, will help maintain the bank's capital adequacy ratio above 11 percent at a time when the bank is experiencing rising credit losses. 


\section{IMF Completes First Review Under Stand-By Arrangement with Latvia and Approves €195.2 Million Disbursement}

The Executive Board of the International Monetary Fund (IMF) today completed the first review of Latvia's performance under an economic program supported by a 27-month StandBy Arrangement (SBA). The completion of the review enables the immediate disbursement of an amount equivalent to SDR 178.4 million (about $€ 195.2$ million or US\$278.5 million), bringing total disbursements under the SBA to SDR 713.8 million (about $€ 780.7$ or US\$1.14 billion).

The SBA, which was approved on December 23, 2008 (see Press Release No. 08/345) for an amount equivalent to SDR 1.52 billion (about $€ 1.66$ billion, or US $\$ 2.37$ billion), entails exceptional access to IMF resources, amounting to 1,200 percent of Latvia's quota in the IMF.

Latvia's economy is suffering a much deeper contraction than envisaged at the launch of the program in 2008. The authorities nevertheless remain committed to an adjustment strategy centered on strong fiscal consolidation. The program has been adjusted to reflect:

- a significant increase in the program's fiscal deficit ceiling in 2009 (up to 13 percent of GDP, compared with 5 percent in the original program) to avoid measures that would harm the most vulnerable, and

- $\quad$ allow for 1 percent of GDP in additional resources for social safety nets.

The IMF's support is part of a coordinated effort with the European Union, the World Bank, Nordic governments and other bilateral creditors that are providing the financing necessary to ensure that essential public services, especially support to those most severely hit by the crisis, can be maintained in the face of a sharp drop in government revenues. 
The authorities are firmly committed to putting the budget deficit on a rapidly declining path from 2010 onward, and have outlined measures to this effect, the details of which will be a key topic for discussion in the next review under the Fund arrangement.

The Board also approved the request for waivers of nonobservance of the end-March 2009 performance criterion on the adjusted cash fiscal balance; the end-March 2009 structural performance criterion on submission of a second supplementary budget law for 2009 to Parliament; and the continuous performance criterion on non-accumulation of domestic arrears by the general government.

Following the Executive Board's discussion on Latvia, Mr. Dominique Strauss-Kahn, Managing Director and Chair stated:

"Latvia's economy is suffering a much deeper contraction than envisaged at the launch of the program. This reflects both the more-pronounced unwinding of the credit and real estate bubble, as well as the much worse international environment than originally anticipated. Although the current account has moved into surplus, the contraction has significantly eroded government revenues, increasing the fiscal deficit.

"The significant revision of the 2009 fiscal deficit target minimizes further pressure on economic activity and increases the scope for spending on social safety nets. Latvia's large fiscal deficit will need to be reduced through strong corrective policies over several years. The 2009 supplementary budget includes initial steps in this direction but greater reliance on structural reforms would make the adjustment more permanent and credible. For the 2010 budget, efforts should focus on preparing sustainable and structurally sound fiscal reforms, on seeking the support of social partners, and on protecting the most vulnerable.

"The authorities have made good progress in stabilizing the financial sector. Important measures include strengthened intervention capacity, an enhanced financial supervision and monitoring framework, and steps to contain risks in Parex Bank. Looking ahead, in light of binding fiscal constraints, the authorities should minimize contingent liabilities from domestic banks, particularly those in state ownership, and restrict issuance of new guarantees.

"The Latvian authorities are committed to putting their economy back onto a sustainable path, through substantial corrective measures, including additional fiscal consolidation. Latvia continues to receive strong international support as it seeks to overcome its present economic difficulties. The European Union, Nordic countries, and other partners are providing considerable financial support and, together with the authorities, remain committed to Latvia's macroeconomic strategy." 


\section{Statement by Mr. Jens Henriksson, Executive Director for the Republic of Latvia and Mr. Gundar Davidsons, Advisor to the Executive Director \\ August 27, 2009}

My authorities express gratitude to staff and management for the timely assistance to Latvia during the current economic problems. The authorities also thank staff for the constructive policy dialogue since the approval of the Stand-by-Arrangement (SBA). The discussion with staff was fruitful and helped to improve policy decisions taken by the authorities.

\section{Economic Developments}

Latvia has been hit by adverse economic developments much harder than initially expected. Both the sharply worsening financing conditions and the collapse of global trade have played an important role in a stronger than expected downslide of economic activity. The fall in GDP by 18 percent year-on-year in the first quarter of 2009 and a further decrease to -19.6 percent in the second quarter were broadly based, with both domestic absorption and exports contracting significantly.

The bursting of the credit and real estate bubbles and the respective economic contraction were considerably amplified by strong repercussions from global financial distress. Two main factors have played an important role in sharper than expected adjustment. First, much worse financing conditions and increased uncertainty had a significant downward impact on credit flow, washing away any signs of stabilization experienced throughout 2008. Second, significantly decreasing export as a result of the global trade collapse was pushing the economy even deeper into recession.

While strong contraction and growing unemployment are taking a toll on the economy, adjustment of past imbalances is under way. The current account deficit was well in double digits as a fraction of GDP a year ago but has been in surplus this year. Trade in goods and services has become positive, reflecting both a sharp adjustment of domestic demand and a shift away from imports as the bursting real estate bubble and tighter financing conditions have decreased the previously excessive demand for mostly imported durable goods.

Price and wage correction has begun, narrowing the gap between wages and productivity opened during boom years. Headline inflation fell to 2.5 percent in July 2009 and inflation expectations have stabilized at close to zero. Excluding VAT and excise tax increases, monthly inflation has been close to zero or even negative for eight months already. Responding to the considerable easing of the labor market and the building up of unemployment, the decline in seasonally adjusted nominal wages started in late 2008 already, reaching a decline of 2 percent quarter-on-quarter in the first quarter of 2009. Leading indicators suggest an ongoing wage correction in the second quarter. Falling costs have already shown up in relative price measures with the real effective exchange rate being on a depreciation path since spring 2009. 
Nevertheless, the economic situation remains difficult. Further output losses are likely before mid-2010 when economic activity is expected to bottom out. Despite some green shoots observed during the recent months - e.g., a positive manufacturing output ( 3 percent seasonally adjusted quarter-on-quarter increase in the second quarter of 2009 , for the first time since early 2008), and improved confidence and employment expectations - the agreed macroeconomic scenario based on the GDP decline of 18 percent in 2009 and of 4 percent in 2010 remains valid with a broadly balanced profile of risks. However, the economy has responded rapidly to the changed conditions through much faster reduction of past imbalances and, given the progress attained so far and the expected continuation of the internal adjustment, my authorities believe that a faster than expected recovery in 2011 and beyond is likely, should assumptions about global developments remain valid.

\section{Fiscal policy and structural reforms}

Much stronger than expected GDP contraction has significantly widened the fiscal gap requiring additional measures to be undertaken to ensure fiscal sustainability. In response to the new economic realities, the Latvian Parliament adopted the second 2009 Supplementary Budget Law, which entails fiscal consolidation amounting to LVL 500 million (around EUR 700 million or 4 percnet of GDP). In particular, this includes LVL 710 million expenditure reducing measures, and LVL 290 million expenditure increasing measures to account for a higher automatic expenditure due to a weaker economy, rising debt burden and increasing appropriations for the EU funded projects. In addition, revenue increasing measures amount to LVL 80 million.

The supplementary budget is based on the agreed macroeconomic scenario and revised revenue forecasts. Recent trends indicate that the budget deficit target of 10 percent of GDP on an accrual basis in 2009 is realistic. During seven months in 2009, the general government budget recorded a deficit (on cash basis) of only 3.3 percent of annual GDP, and budget execution is regularly monitored in order to avoid the risk of exceeding the committed fiscal targets.

Though part of the expenditure cuts are across-the-board, as correctly noted by staff, they provide a binding framework for line ministries to implement reforms and improve spending efficiency. Between 2004 and 2008, public expenditure had increased more than two times, building significant inefficiencies in the expenditure base. Consequently, there is room for optimizing expenditure. The authorities agree that there are implementation risks; however, most line ministries have already agreed and specified expenditure cuts for 2009 and the issue is open only in the health care sector.

While respecting staff estimates, we clearly see that notable buffers have been built into the 2010 budget baseline and consequently the program scenario, especially on the expenditure side, that my authorities feel were not sufficiently discussed. According to our calculations, which are supported by the European Commission estimates, the agreed consolidation measures amounting to 4 percent of GDP on top of the carry-over 
effects from 2009, should be sufficient to reach our deficit target of 8.5 percent of GDP on an accrual basis in 2010.

Consolidation measures for 2010 are aimed at both increasing revenue and decreasing budget expenditure. On the revenue side, a comprehensive plan to broaden the base of the personal income tax and of the real estate tax and to increase the real estate tax rate is under preparation. On the expenditure side, the authorities will carry out a broad public service reform and, based on a series of functional audits, undertake a number of structural reforms in many areas already identified, including agriculture, defense, foreign affairs, transport, culture, social security and others.

Should the above mentioned measures prove insufficient to ensure a lower fiscal deficit in 2010 compared to this year, additional measures amounting to 2.5 percent of GDP have been identified as feasible. They include an increase in headline VAT rate from 21 to 23 percent, the introduction of a more progressive personal income tax system where the average effective tax rate would be raised to around 25 percent for earnings in excess of LVL 500 per month, and additional expenditure cuts during the budgeting process, including fundamental revisions of line ministries' budget bases. However, as already stated above, the agreed consolidation measures amounting to 4 percent of GDP are likely to be sufficient to further reduce the budget deficit beyond 2009, even if additional spending on social safety nets were included. While my authorities are fully committed to taking the additionally identified measures, they are likely to be necessary should the authorities fail to deliver the above mentioned structurally grounded expenditure cuts.

In these challenging times, the authorities are taking due care of the most vulnerable part of society by instituting emergency social safety net measures. These measures include, but are not limited to, compensating costs for medication and patient copayments in hospitals, increasing the guaranteed minimum income and housing support, ensuring transportation for pupils in the areas where schools are being closed down, creating emergency social employment in municipalities. Emergency social safety net measures are being elaborated in cooperation with World Bank experts in order to mitigate the adverse effects of economic contraction and structural reforms on the least protected part of the population.

A remarkable difference of the 2010 budgeting process is the substantial involvement of social partners and the society in the budget preparation already at an early stage, increasing credibility of the much needed consolidation measures. The considerably broadened involvement of all stakeholders shall significantly increase the reform ownership, thus pushing up the probability of a successful budget reform for the coming year.

All political parties that form the government are fully aware of the recent and future challenges and this is well confirmed by the fact that the July 2009 Letter of Intent was signed not only by the Prime Minister, Minister of Finance, Chairwoman of 
the Financial and Capital Market Commission and Governor of the Bank of Latvia, but also by all coalition parties forming the government. The schedule for preparing the 2010 budget has been adopted by the government and authorities clearly understand the importance of passing the 2010 Budget Law by the agreed deadlines.

The government and the responsible public administration institutions are strongly committed to carrying out all necessary steps to fulfill Maastricht criteria, which would ensure introduction of the euro as soon as possible. According to the present forecasts, 2014 seems a viable euro introduction target date and the authorities are committed to doing whatever it takes to reach this target.

\section{Monetary and financial sector policies}

Monetary policy responded to the sharply falling economic activity and strains aggravating in the financial system in late 2008. The decision to lower reserve requirements in late 2008 was taken in the middle of November, amidst mounting financial stability concerns following the Parex takeover. Inter alia, it helped to address the squeezing liquidity conditions of the banking sector, thereby providing a much needed alleviation for the financial system at a very turbulent time. As significant buffers had been accumulated during boom years, it allowed providing support to the banking sector without compromising the sustainability of the fixed exchange rate.

The resulting liquidity surplus by itself was not undermining the stability of the exchange rate. This was evident from the relatively calm situation in the currency market at the very beginning of the year. Similarly, in the absence of FX pressures, surplus liquidity conditions have coincided with a stable exchange rate in the middle of the allowed fluctuations corridor during the past two months.

In the authorities' view, the heightened risk aversion rather than the downward pressure of liquidity surplus on domestic interest rates exaggerated the demand for foreign currency and provoked outflows during the spring and early summer of 2009, showing up in sizable central bank interventions. As partly discussed in the staff report, the uncertainty was caused by a series of shocks: political uncertainty after the previous government stepped down, uncertainty surrounding municipal elections, misleading and exaggerated press reports on top of bold statements and speculations regarding the stability of the lats, amplified by the delayed program review and ongoing consultations regarding future policies in response to a much stronger than expected economic contraction.

The reduction in official interest rates, according to the authorities' view, should be considered together with the spread between the official lats and euro rates, given the exchange rate peg of the lats to the euro. On the backdrop of significant ECB rate cuts since October 2008, even after the Bank of Latvia lowered the refinancing rate from 6 to 4 percent, the spread between the corresponding lats and euro refinancing rates is nearly twice as high as in September 2008, mitigating concerns of falling interest rates from the exchange rate stability point of view. 
Authorities share staff's view that significant program financing inflows on the backdrop of heightened fiscal deficit warrant adjustments of the liquidity management strategy to avoid excess money market volatility, at the same time fully respecting the limitations imposed by a quasi-currency board arrangement. While authorities see this could be well attained within the current operational framework, they would be willing to share the experiences and discuss the issue with IMF staff. Only then the final decision on fine-tuning the current liquidity management strategy could be taken by the Bank of Latvia.

Many other steps have been taken to safeguard the financial system. Intervention capacity has been strengthened by developing a new Law on Bank Takeover, amendments to the Credit Institution Law, the Deposit Guarantee Law and the Law on the Financial and Capital Market Commission. The Financial and Capital Market Commission (FCMC) has improved supervision and monitoring of the sector by enacting new regulations on assessing asset quality and on provisioning, and by issuing supervisory guidance on banks' internal capital adequacy assessment processes thus shoring up capital buffers; liquidity regulations are also being revised in line with the recent developments in the best international practice. Moreover, the FCMC has stepped up its monitoring of individual banks and enacted new reporting requirements. In the meantime, the IMF has been requested to provide technical assistance to improve the operational aspects of the Deposit Guarantee Fund.

At present, the banking sector is adequately capitalized having a system-wide capital adequacy ratio above 12 percent, and overall banks have sufficient liquidity. With the continuing economic downturn and deteriorating quality of banks' loan portfolios, capital buffers should be maintained significantly above the regulatory minimum. Several banks have already responded to these developments with new capital injections from their shareholders.

Progress has been made in resolving the problems of Parex, the second-largest Latvian bank. An agreement to reschedule the bank's syndicated loans was reached in March. In April, the government and the EBRD agreed on the EBRD's investment of 25 percent of Parex equity and a subordinated loan. In May, the state recapitalized Parex. The FCMC will keep monitoring Parex liquidity, ensuring that its management's restructuring plans do not entail undue risks. The partial deposit freeze will be removed once conditions stabilize.

The FCMC remains committed to closely monitoring banks, also by using the stresstesting framework more widely. Forward-looking assessments to ensure that banks maintain adequate liquidity and solvency buffers will be completed supplementing topdown stress tests with bottom-up stress tests run by banks on the basis of uniform macroeconomic scenarios and linkage of these scenarios to loan performance. Results will be used to assess potential needs for additional own funds to build up banks' solvency.

Contingency planning and crisis management capacity are being refined. Building on the progress in the financial sector to date with the finalization of a comprehensive 
strategy for bank recapitalization and resolution of authorities will ensure a stronger financial sector while having in place strong contingencies in the event of shocks.

\section{The request}

On the basis of the information provided herein and in the Staff Report and authorities' strong commitment to pursue the measures identified in the Letter of Intent, the authorities request the Board's approval for the completion of the First Review and Financing Assurances Review under the SBA. As the depth of economic contraction has sharply reduced government revenues, it has been impossible to fulfill fiscal targets without exacerbating already painful dislocations. On the basis of the 2009 corrective measures and the authorities' plans for the future detailed herein and in the Letter of Intent, we request waivers for the non-observance of the end-March 2009 performance criterion on the fiscal deficit, and the continuous performance criterion on nonaccumulation of domestic arrears by the general government. Also, in light of the change of the government in March, additional time was needed to prepare the supplementary budget. We are therefore also requesting a waiver for the end-March 2009 structural performance criterion on its submission to parliament. 